\title{
EL ROBO COMO COACCIÓN
}

Antonio Bascuñán Rodríguez.

1. Introducción. 2. La concepción moderna del delito de robo: 2.1 La teoría del robo de Carpzov, Böhmer y Feuerbach; 2.2 La regulación del robo en la codificación alemana, francesa y belga; 2.3. La codificación española; 2.4. La regulación del robo en el Código Penal chileno: a. La Ley general de hurtos y robos de 7 de Agosto de 1849; b. La labor de la Comisión Redactora del Código Penal; c. Las reformas posteriores. 3. Consecuencias dogmáticas: 3.1. Robo y extorsión; 3.2. La relación cronológica entre el ejercicio de violencia o intimidación y la apropiación; 3.3. La relación funcional entre el ejercicio de violencia o intimidación y la apropiación; 3.4 Las relaciones entre el tipo básico y los tipos calificados de robo; 3.5. La relación entre el robo y el así denominado "robo por sorpresa"; 3.6. La relación entre el robo y la autotutela ilícita. 4. La coacción como elemento de injusto del robo: 4.1. La posición de la coacción en el sistema de la Parte Especial; 4.2. El robo como coacción grave: a. La intimidación como amenaza coercitiva grave; b. La violencia en las personas como violencia coercitiva grave; 4.3. La tesis de la afectación de la seguridad física; 4.4. La interpretación desde el robo calificado. 5. Consideraciones de lege ferenda: 5.1. La racionalidad político-criminal de la penalidad y la regulación del delito de robo; 5.2. El futuro legislativo de la apropiación coercitiva; 5.3. Resumen final.

“..y como Marciano dijese: no hice ninguna violencia, el César dijo: ¿y crees tú que solamente hay violencia si se hiriere a hombres?" (Calístrato, libro V. De Cognitionibus, Dig. 48, 7, 6)

\section{Introducción**}

En el Capítulo Cuarto de su libro titulado "Hurto y Robo"1, Jorge Mera Figueroa efectúa un análisis de los problemas dogmáticos y de política criminal que plantea el tipo básico del delito de robo con violencia e intimidación en las personas (en adelante "robo" sin otro calificativo), configurado y sancionado en el artículo 436 del Código Penal, en concordancia con los artículos 432 y 439 del mismo Código. Con tal propósito, Jorge Mera desarrolla una interpretación de los conceptos de violencia e intimidación en las

\footnotetext{
* Profesor Asistente de Derecho Penal de la Universidad de Chile.

** Agradezco a los Profesores María Inés Horvitz Lennon y Jorge Bofill Gentzsch por sus comentarios críticos a una versión preliminar de este artículo. Juan Pablo Mañalich Raffo, estudiante de la Facultad y Ayudante-Alumno de Derecho Penal, fue de gran ayuda en la revisión de la jurisprudencia reciente y la corrección de la última versión del texto; Samuel Tschorne Venegas, estudiante, saneó más de una vez el formato electrónico del texto, Rodrigo Gil Ljubetic e Ignacio Molina González, egresados, formularon en su momento valiosas sugerencias de estilo: cumplo aquí con agradecer a todos ellos por su interés y generosidad. Finalmente, estoy en especial deuda con el Ayudante de Derecho Penal de la Facultad, Gonzalo Medina Schulz, por su colaboración en la recopilación de antecedentes históricos.

${ }^{1}$ Editorial Jurídica Conosur Ltda., Santiago, Marzo de 1995. El texto apareció originalmente publicado el año 1994, como No 3 de la Serie de Publicaciones Especiales de los Cuadernos de Análisis Jurídico de la Universidad Diego Portales. Con anterioridad a la publicación de ambos textos algunas ideas del autor ya habían aparecido en su artículo Protección penal de la propiedad y posibilidades rectificadoras de la dogmática, en: Cuadernos de Análisis Jurídico de la Escuela de Derecho de la Universidad Diego Portales, No 21, p. 51 y ss. Con posterioridad a la primera edición de su obra, el autor volvió a formular sus planteamientos en su comentario a dos sentencias sobre la materia, aparecido en: Revista de Ciencias Penales, Tomo XLII No 3 (1990-1994), p. 118 y ss.
} 
personas que es planteada como una concepción alternativa y radicalmente contrapuesta a la concepción mantenida por la doctrina y la jurisprudencia.

El argumento central de esta concepción alternativa consiste en las siguientes tres tesis:

Primera tesis: La gravedad del marco penal establecido como consecuencia jurídica de la comisión del delito de robo con violencia e intimidación en las personas exige considerarlo como un delito pluriofensivo y complejo.

Segunda tesis: Para fundamentar la complejidad y pluriofensividad del robo no basta con postular la existencia de una lesión a la libertad personal como elemento adicional de lo injusto del hurto, sino que se requiere constatar la creación de un peligro para la vida o de un peligro grave para la incolumidad personal.

Tercera tesis: La fundamentación de lo injusto del robo en la apropiación de cosa mueble con la creación de un peligro para la vida o un peligro grave para la incolumidad personal encuentra su correlato típico en la exigencia de empleo de violencia e intimidación en las personas; en este contexto, estos términos no designan simples medios coactivos de apropiación de la cosa mueble ajena, sino formas de afectación de la seguridad física de las personas.

La concepción de Jorge Mera es un intento de fundamentar una interpretación restrictiva de los medios comisivos del delito de robo, contribuyendo con ello a una delimitación más restringida del ámbito típico de un delito sancionado con una pena grave. Esa es una idea tan correcta como extendida en la doctrina y el derecho comparados. Entre los autores españoles, por ejemplo, puede citarse la opinión de Luis Felipe Ruiz Antón, quien desarrolla un concepto de violencia como acometimiento agresivo contra las personas y un concepto de intimidación como amenaza de un mal especialmente grave ${ }^{2}$. Aunque con divergencias de detalle, esta interpretación restrictiva de los medios comisivos del robo se constituyó en la última década en la postura dominante en la doctrina española ocupada de la antigua regulación, vigente hasta 19943. La recepción de esta orientación político-criminal en el nuevo Código Penal español de 1995 ha tenido lugar mediante la incorporación de la técnica legislativa inversa, consistente en establecer la posibilidad de una atenuación de la pena para los casos menos graves ${ }^{4}$. En el Derecho penal alemán, la concepción restringida de los medios comisivos del robo ha encontrado incluso consagración legal en términos directos. El \249 del Código Penal alemán exige como medios comisivos del robo el uso de "violencia contra la persona" o de "amenaza con peligro actual para el cuerpo o la vida". Interpretando esta disposición,

\footnotetext{
${ }^{2}$ Luis Felipe Ruiz Antón, Los robos con violencia o intimidación en las personas, en: Manuel Cobo del Rosal, Miguel Bajo Fernández: Comentarios a la Legislación Penal, Tomo V, Volumen 2, Madrid, 1985, p. 1049 y ss. (esp. p. 1057-1063).

3 Así: Vives Antón, en: Cobo del Rosal y otros, Derecho Penal-Parte Especial, 1988, p. 783 y ss.; Bustos Ramírez, Manual de Derecho Penal-Parte Especial, 2a ed. (1991), p. 174 y ss.; Cobos Gómez de Linares, Barja de Quiroga, Rodríguez Ramos, Manual de Derecho Penal-Parte Especial, Tomo II, 1991, p. 153 y ss.; Bajo Fernández, Pérez Manzano, Manual de Derecho Penal-Parte Especial, Tomo II, $2^{\mathrm{a}}$ ed. (1993), p. 101 y ss. González Rus, Manual de Derecho Penal (Parte Especial),Tomo II, 19, p. 73 y ss. No sostienen la necesidad de restringir el ámbito de alcance de los medios comisivos del robo: Rodríguez Devesa, Derecho Penal Español-Parte Especial, $15^{a}$ ed. (1992), p. 429 y ss.; Muñoz Conde, Derecho Penal-Parte Especial, $10^{\mathrm{a}}$ ed. (1995), p. 260 y ss.

4 Art. $242 \mathrm{~N}^{\circ} 3$, cuyo origen se encuentra en el art. 246 del Proyecto de Código Penal de 1992. Como supuesto paradigmático de caso menos grave de robo se cita el así denominado "robo por sorpresa" (Gonzalo Quintero Olivares y otros, Comentarios a la Parte Especial del Derecho Penal, 1996, p. 471).
} 
la postura dominante de la doctrina en Alemania exige que la violencia en el robo satisfaga requisitos específicos, adicionales a los de la violencia como medio coercitivo en general, y que la amenaza con peligro para el cuerpo se traduzca en una amenaza con peligro de daño grave para la libertad, autodeterminación sexual o incolumidad personal ${ }^{5}$.

Lo que diferencia la interpretación restrictiva de Jorge Mera de la mantenida por la doctrina española y alemana es su radical negación de la relevancia de la función de la violencia y la intimidación como medios coercitivos en la fundamentación de lo injusto del delito de robo. Por más restrictiva que sea la interpretación de los medios comisivos del robo, todos los autores alemanes y la gran mayoría de los españoles coinciden en considerar lo injusto de la coacción -o el efecto de su combinación con la lesión de la propiedad-como el elemento diferencial del robo frente al hurto.

El ejemplo más claro de esta concepción se encuentra en la importante contribución monográfica de Bernd Schünemann al estudio de este delito. No obstante ser uno de los más decididos adversarios de la incorporación de una concepción extensiva de la violencia en el ámbito del delito de robo, es decir, a pesar de negar la equiparación de los ámbitos típicos de la coacción violenta y el robo violento, Schünemann no vacila en sostener que...

"Tal como lo muestra un breve vistazo, el tipo del robo representa una combinación de hurto y coacción de modo tal que la sustracción de la cosa perseguida con intención de apropiación debe ser reforzada mediante una acción calificada de coacción. Mientras que sin la existencia del $\int$ 249 en un caso semejante se daría un concurso ideal entre el $\ 242$ [hurto] y el $\$ 240$ [coacción] (...), el tipo del robo expresa la valoración del legislador en orden a que la acumulación de lo injusto del hurto a la coacción significa un potenciamiento de la energía criminal y que por lo tanto el robo debe ser calificado como un crimen." 6

Según Jorge Mera, en cambio, en el contexto típico del robo, la violencia y la intimidación no son primariamente medios coercitivos de apropiación de una cosa mueble, sino formas de afectación de la seguridad personal. Es decir, no son una clase o categoría especial de violencia coercitiva (art. $494 \mathrm{~N}^{\circ} 16$ ) o de amenaza condicional (arts.

\footnotetext{
5 Así: Schünemann, Raub und Expressung, Juristische Arbeitsblätter 1980, p. 349 y ss. [350-351]; Samson, en: Rudolphi, Horn, Günther, Samson, Systematischer Kommmentar zum Strafgesetz-buch, $20^{a}$ remisión (1986), $\mathbb{S} 249$, núms. 9 y ss.; Maurach, Schroeder, Maiwald, Strafrecht-Besonderer Teil, Teilband 1, $7^{\mathrm{a}}$ ed. (1988), \35-II, núms. 15 y ss.; Eser, en: Schönke-Schroeder, Strafgesetzbuch-Kommentar, 24a ed. (1991), \249, núms. 4 y ss.; Herdegen, Strafgesetzbuch-Leipziger Kommentar-Großkommentar, $11^{\mathrm{a}}$ ed. (1994), \249, núms. 3 y ss.; Krey, Strafrecbt-Besonderer Teil, Band 2: Vermögensdelikte, $10^{a}$ ed. (1995), \ 3 núms. 186 y ss.; Gössel, Strafrecht-Besonderer Teil, Band 2, 1996, \13, núms. 8 y ss.; Lackner, Strafgesetə̧buch mit Erläuterungen, $22^{a}$ ed. (1997), \$249, núms. 2 y ss.; Günther, en: Rudolphi, Horn, Günther, Samson, Systematischer Kommmentar zum Strafgesetz-buch, 43ª remisión (1998), \249, núms. 7 y ss.; Kindäuser, Strafrecht-Besonderer Teil-II, Teilband I, $2^{a}$ ed. (1999), \12, núms. 16 y ss.

${ }^{6}$ Raub und Erpressung, cit., p. 349. El equivalente a este fragmento en la doctrina española es el siguiente pasaje de Zugaldía Espinar. “....al ser el robo un delito pluriofensivo, junto al bien jurídico señalado [el del hurto], habrá que entender que con el delito de robo se ataca también otro bien jurídico personalísimo, como es el de la libertad (...); el robo aparece así como un hurto más violencia o amenazas, esto es, como una figura independiente que, de hecho, deroga las reglas generales del concurso de los delitos de hurto-coacciones" (Delitos contra la propiedad y el patrimonio, Madrid, 1983, p. 18-19).
} 
$296 \mathrm{~N}^{\circ} 1$ y 2, 297), sino una denominación genérica para conductas que crean un riesgo o peligro concreto para la vida o la incolumidad personal. Este es el sentido preciso con que el autor apela al carácter complejo y pluriofensivo del robo como fundamento de su interpretación de la violencia y la intimidación.

En toda su radicalidad, la tesis de Mera es indudablemente falsa. Cualquier interpretación de los medios comisivos del robo debe partir de su carácter de medios coercitivos funcionales a la apropiación de la cosa mueble como premisa básica del análisis dogmático. Lo dispuesto en los arts. 432 y 439 del Código Penal chileno no deja el menor lugar a dudas a este respecto 7 . En el contexto del tipo del robo, el uso de violencia o intimidación en las personas mantiene una conexión de sentido primaria con el constreñimiento del comportamiento ajeno, cuyo caso paradigmático es el constreñir a tolerar la apropiación de la cosa mueble. Tan evidente es esta función, que ella constituye un dato positivo indesmentible aún para el propio Jorge Mera. Este autor no puede, en efecto, desconocer que...

"Para que exista violencia o intimidación deben concurrir, obviamente, las exigencias del artículo 439, y emplearse dichos medios en la oportunidad y con alguna de las finalidades señaladas en el art. 433." 8

Pero las condiciones exigidas por la ley para que el uso de violencia o intimidación sea típicamente relevante no son una obviedad, como lo insinúa Jorge Mera, ni configuran un concepto meramente "práctico, operativo", desprovisto de significación para la comprensión de los elementos constitutivos de lo injusto del robo, como él lo sostiene? Muy por el contrario, es precisamente en esta definición del uso de la violencia o la intimidación donde se encuentra expresado el carácter peculiar del delito del robo, compuesto por lo injusto del hurto y lo injusto de la coacción, tal como lo hace ver Schünemann. Esta es la idea regulativa que caracteriza la concepción moderna del robo, por oposición a la concepción del delito de rapinna en el derecho común con base en el derecho romano, que veía en él un caso de hurto con violencia susceptible de sanción como delito público a título de violencia (crimen vis), sin especificar la naturaleza exclusivamente coercitiva de ésta. A la demostración de dicha tesis histórica se encuentra dedicada la segunda sección de este artículo, que es también la más extensa. Allí espero mostrar cómo surgió la concepción moderna del robo en el siglo XVIII y cuán estrechamente coincidente con esta concepción es la regulación española (chilena) del robo.

Frente a esta idea regulativa, la versión radical de la tesis de Jorge Mera implica un retroceso intelectual de más de doscientos años en términos de historia de la dogmática penal. Para ratificar esta conclusión, en la tercera sección se examinan cinco problemas básicos del delito de robo. Con ocasión de cada uno de estos problemas espero demostrar

7 El art. 432 define como autor de robo al que "se apropia cosa mueble ajena usando de violencia o intimidación en las personas". El art. 439 define los conceptos de violencia e intimidación en la persona estableciendo en su parte final una fórmula general consistente en considerar como tal "cualquier otro acto que pueda intimidar o forzar a la manifestación o entrega".

${ }^{8}$ Hurto y robo... cit. [nota 1], p. 114.

${ }^{9}$ Op. cit., p. 113. 
que sólo la concepción del robo como coacción permite darles un tratamiento dogmático diferenciado y correcto.

La tesis de Mera debe moderar su radicalidad si quiere ser verosímil. En tanto elaboración dogmática, su propuesta sólo puede ser aceptable en la medida en que adopte el mismo marco conceptual asumido por la postura dominante en la doctrina española y alemana, esto es, bajo la premisa de que la dimensión de afectación de la seguridad personal que se exige a la violencia y la intimidación no sustituye sino que se agrega a la función coercitiva de estos medios. Por cierto, aún en este contexto, la tesis de Mera sigue siendo incomparablemente más extrema en sus consecuencias que la postura dominante en la doctrina española y alemana, particularmente en lo que respecta a la intimidación.

La explicación de ello se encuentra en la forma como Jorge Mera asume desde un punto de vista dogmático la necesidad de fundamentar a nivel de lo injusto la imposición de una pena tan grave como la establecida por la ley al delito de robo, que en el Código Penal chileno es superior a la pena del delito de castración (art. 395) e incluso a la del homicidio simple (art. $391 \mathrm{~N}^{\circ}$ 2). Como se ha visto, su tesis consiste en sostener que esta penalidad encuentra su fundamento en la pluriofensividad del robo, y que la vulneración de la libertad personal -el bien jurídico protegido en lo injusto de la coacción- no alcanza a trascender significativamente el ámbito de lo injusto de la lesión a la propiedad. A juicio de Mera, sólo la afectación de la seguridad personal puede fundamentar esa pluriofensividad, requerida por la pena.

En mi opinión, el argumento de Jorge Mera se basa en un serio error dogmático e incurre en un error político-criminal más grave aún.

La falta de consideración de la relevancia de la lesión de la libertad personal como elemento de lo injusto del robo es el resultado de un análisis insuficiente de la posición de los delitos contra la libertad, en particular de la coacción mediante amenazas, en el sistema de la Parte Especial del Código Penal. Algo semejante cabe decir de la asignación de dicha relevancia a la afectación de la seguridad personal. Esta noción es introducida y manejada como dimensión de lo injusto con imprecisión excesiva, y su postulación como un disvalor fundamental de lo injusto del robo es incongruente con el sistema del propio Código Penal. Tal como intentaré mostrarlo en la cuarta sección de este artículo, un adecuado análisis dogmático lleva a la conclusión que, conforme al sistema del Código, la lesión a la libertad personal se encuentra en mucho mejor posición que la afectación de la seguridad personal para fundamentar una gravedad adicional de lo injusto del robo frente al hurto.

De la demostración anterior no se deduce, sin embargo, que la lesión a la libertad personal alcance a hacer razonable desde un punto de vista político-criminal la pena actualmente asignada al delito de robo en el Código Penal. En un sistema racional de asignación de penas, basado en un criterio de proporcionalidad en relación con el disvalor de injusto -actual o potencial- de las conductas, la pena asignada al delito de robo es una pena desproporcionada, incluso desde la perspectiva propuesta por Jorge Mera. Su teoría no sólo no mitiga esta insuficiencia, sino que además la encubre. Tal como espero mostrarlo al comienzo de la quinta sección de este artículo, el mayor reparo que cabe hacer a esta teoría es su efecto legitimatorio de la actual regulación del robo. Así, a las insuficiencias de su análisis dogmático, esta teoría agrega graves defectos de política- 
criminal. Pues es una mala política jurídica aquella que renuncia a su función crítica de la legislación positiva.

Con todo, y argumentando ahora de lege ferenda, no puede negarse que aún si recibiera una pena proporcionada, el delito de robo seguiría constituyendo una anomalía sistemática desde el punto de vista de las relaciones concursales entre el delito de coacción y el resto de la Parte Especial. Es un mérito innegable de Jorge Mera haber detectado y expuesto esta anomalía al fundamentar su tesis de la falta de trascendencia de la lesión a la libertad personal. No obstante, al momento de argumentar ahora de lege ferenda, Mera arroja por la borda su descubrimiento para formular sugerencias incompatibles con él. Tal como espero mostrarlo en la segunda parte de la quinta sección, una atenta consideración de lege ferenda lleva a la conclusión que el problema sistemático antedicho se presenta inevitablemente, ya sea desde la perspectiva de los delitos contra la libertad como desde la perspectiva de los delitos contra el patrimonio. Tal como también lo sostendré, la solución razonable a este problema puede seguir diversos caminos, menos el propuesto por Jorge Mera. Pues su solución es contradictoria hasta con sus propias premisas.

No obstante sus deficiencias, la interpretación de Jorge Mera ha comenzado a tener acogida en la jurisprudencia ${ }^{10}$. La explicación de este fenómeno se encuentra en el interés judicial en eludir la aplicación de la pena establecida en el art. 436 C.P., que va de cinco años y un día a veinte años de presidio. Este es un propósito práctico con el cual difícilmente se puede estar en desacuerdo, dado lo desproporcionado de la pena. La crítica a la tesis de Mera pareciera poner al intérprete en una incómoda posición de crítica frente a su utilización como excusa argumental para evitar la vulneración desproporcionadamente grave de la libertad de una persona.

El punto de partida para enfrentar esta cuestión práctica es el reconocimiento de que el legislador ha distorsionado el sistema de penas del marco legal, de modo tal que ya no es reconocible la jerarquización originaria del Código Penal, basada en el principio de proporcionalidad entre pena y disvalor de injusto ${ }^{11}$. Ante esta irracional agravación de penas es explicable que la jurisprudencia judicial y el foro desplieguen estrategias argumentativas para eludir sus efectos. La resistencia opuesta por la praxis a la irracionalidad legislativa es en definitiva una cuestión de desobediencia en virtud de la asunción de la responsabilidad por las consecuencias. La actitud del jurista frente a este fenómeno puede ser de crítica o de comprensión, dependiendo de cuál sea su juicio acerca de la responsabilidad política del juez desobediente. Cuando el legislador ha eludido su

\footnotetext{
${ }^{10}$ Su recepción se ha producido principalmente en la jurisprudencia de la Iltma. Corte de Apelaciones de San Miguel, primero en votos disidentes o de prevención, y luego en votos de mayoría, todos ellos redactados por Carlos Künsemüller Loebenfelder. Los casos iniciales en los que puede constatarse esta recepción son los siguientes: contra Mario Gabriel Baeza Faúnder, sentencia de 19 de Mayo de 1993, publicada en: Revista de Ciencias Penales, Tomo XLIII (1994) No 3, p. 113-115; contra Juan Luis Guzmán Henriquez, sentencia de 30 de Marzo de 1995, en: Revista Gaceta Jurídica No (1995), p. 146-150; contra Pedro Amaya Marchant, sentencia de 10 de Enero de 1997, en: Revista Gaceta Jurídica No 199 (1997), p. 143-146; contra Carlos Antonio Soto González, en: Revista Gaceta Jurídica No 199 (1997), p. 146-148. Esta recepción ha generado dos significativas líneas jurisprudenciales, una de ella relativa al robo por sorpresa y la otra referida a la interpretación de la intimidación como medio comisito del robo, que son analizadas detenidamente más adelante (infra, .3.5 y 4.2a, respectivamente).

${ }^{11}$ Las penas de los delitos de hurto, robo con fuerza en las cosas y robo no son las originarias del Código. Tampoco lo son las penas de los delitos en que más evidentemente se rompe el principio de proporcionalidad, como la privación de libertad (art. 141), la sustracción de menores (art. 142) y la violación de impúberes (art. 362). La distorsión de la proporcionalidad de las penas es un fenómeno de la post-codificación.
} 
responsabilidad por las consecuencias, que el juez la asuma puede ser considerado tanto como un acto de responsabilidad o como de suma irresponsabilidad.

A pesar de lo anterior, en su papel de intermediario entre la aplicación del derecho vigente y su reforma, la tarea del jurista pasa por constatar y exponer el fenómeno de la desobediencia judicial responsable, para hacer responsable al legislador. Lo que no puede hacer el jurista es ocultar la irresponsabilidad legislativa y la desobediencia judicial, asignando a la decisión del legislador un sentido del que carece para proveer una justificación falaz a la decisión del juez. Por esa vía se inmuniza al sistema jurídico respecto del sistema político, en circunstancias que lo que se requiere es que el sistema político asuma y satisfaga las demandas de definiciones racionales que le plantea el sistema jurídico.

En suma, las páginas que siguen en ningún caso brindan una apología políticocriminal del programa punitivo del Código Penal actualmente vigente. Su finalidad es criticar una elaboración doctrinal que, con la pretensión de desarrollar una dogmática "rectificadora" de la legislación, en definitiva lo que hace es mistificarla. Cuando aquí se defiende la tesis de que también en el Código Penal chileno el robo es un delito compuesto de hurto y coacción, con ello se sostiene que precisamente por tal razón la pena establecida por la ley para el robo debe ser objeto de reforma legal.

\section{La concepción moderna del delito de robo}

\subsection{La teoría del robo de Carpzov, Böhmer y Feuerbach ${ }^{12}$}

Sin perjuicio de la configuración que el delito de robo recibió en las distintas formas de derecho estatutario de los diversos sistemas jurídicos existentes en la Europa medieval o del antiguo régimen, el derecho común europeo encontraba un punto compartido de referencia para la conceptualización de la apropiación violenta de cosas ajenas en la regulación de los delitos de furtum, rapinna y vis en el Corpus Iuris Civilis, y muy particularmente en el Digesto ${ }^{13}$. El principio sistemático fundamental era relativamente simple: la contractación de cosa mueble ajena contra (o sin) la voluntad de su dueño, poseedor o detentador era constitutiva de hurto (furtum), y, para el caso en que hubiera arrebatamiento de la cosa acompañado de violencia (rapinna), existía un régimen especial,

\footnotetext{
12 Sobre la evolución del concepto de robo en el derecho común alemán: Mittermaier, Notas I y II al \ 353 de la $14^{\mathrm{a}}$ ed. (1847) del tratado de Feuerbach (infra, nota 24); Frank, Raub und Erpressung, en: Vergleichende Darstellung des Deutschen und Ausländischen Strafrechts, Besonderer Teil, Tomo VI, 1907, p. 180 y ss.; Radbruch, Der Raub in der Carolina, en: Libro-Homenaje a Pappenheim, 1931 (reedición de 1981), p. 37 y ss.; Schaffstein, Raub und Erpressung in der deutschen gemeinrechtlichen Strafrechtsdoktrin, insbesondere bei Carpzov, en: Libro-Homenaje a Michaelis, 1972, p. 281 y ss. El estudio más completo se encuentra en la tesis doctoral de Michael Landmesser, Der Raub von der Carolina bis zum bayerischen Strafgesetzbuch von 1813, 1969.

${ }^{13}$ Los lugares más relevantes del Digesto para el tratamiento de esta problemática son: la actio quod metus causa (Dig. 4, 2), los interdictos posesorios de vi et de vi armata (Dig. 43, 16) y quod vi aut clam (Dig. 43, 24), los delitos privados de furtis (Dig. 47, 2), de vi bonorum raptorum (Dig. 47, 7) y de concussione (Dig. 47, 13) y los delitos públicos de vi publica y de vi privata (Dig. 48, 6 y 7). En adelante, se utilizará el término "rapinna" para designar la acción que es el presupuesto paradigmático de la actio de vi bonorum raptorum. Este es un uso coincidente en lo esencial con la terminología de los autores del derecho común, pero que no es invariable en la doctrina. Carrara, por ejemplo, denomina "rapiña" al arrebatamiento en las circunstancias de nuestro "robo por sorpresa", y "hurto violento" a nuestro robo con violencia o intimidación en las personas (Programma del Corso di Diritto Criminale dettato nella R. Università di Pisa, $3^{\mathrm{a}}$ ed. (1875), \$2151). Este uso del término "rapiña" es compartido entre nosotros por Gustavo Labatut, Derecho Penal, Tomo II, $7^{\mathrm{a}}$ ed. (1983), p. 204.
} 
al que se añadían las consecuencias de la violencia (vis). No obstante esta aparente simplicidad, tanto el concepto de los bienes arrebatados por violencia (vi bonorum raptorum) como la regulación del crimen vis suscitaban dificultades sistemáticas y conceptuales. De todas las cuestiones que dividían la opinión de los tratadistas y prácticos, las más relevantes eran las dos siguientes:

a) El concepto de violencia (vis) era incierto, particularmente en lo que respecta a si el delito requería o no una afectación efectiva de otra persona; la postura doctrinaria que daba una respuesta negativa a esta cuestión, avalada por distintos pasajes del Digesto, incluía en el concepto del crimen vis o de la vis propia de la actio de vi bonorum raptorum y de los interdictos posesorios la violencia que incidía solamente en las cosas, el aprovechamiento de una situación de violencia o de catástrofe y el comportamiento manifiestamente dispuesto a la agresión, concretado por ejemplo en el hecho de portar armas.

b) Una venerable tradición conceptual proveniente del derecho canónico afirmaba la distinción tajante entre la coactio absoluta (posteriormente vis absoluta), es decir, la coacción consistente en suprimir la voluntad del coaccionado, y la coactio conditionalis (posteriormente vis compulsiva), es decir, la coacción que condiciona gravemente pero deja subsistente la voluntad del coaccionado ${ }^{14}$; conforme a una postura doctrinaria, diversos pasajes del Digesto parecían recoger esta distinción en el concepto de vis propio de la rapinna, denominado por los glosadores "vis ablativa", de modo tal que quedaban excluidos del ámbito de este delito los casos de tradición forzada pero voluntaria de una cosa.

No cuesta mayor esfuerzo advertir la incompatibilidad de ambas posturas doctrinarias con el moderno concepto de robo como apropiación mediante coacción.

La primera postura impugna derechamente la concepción de la violencia como coacción, sustituyéndola por una noción indiferenciada de acometimiento agresivo, que como tal sólo requiere un cuerpo como su objeto, siendo indiferente que sea el cuerpo de un ser humano, un animal o una cosa. Semejante noción de violencia hace por supuesto imposible la distinción entre el robo propiamente tal y el hurto calificado por el vencimiento o ruptura de medios de resguardo, denominado entre nosotros "robo con fuerza en las cosas". Si el despliegue de violencia sobre cualquier objeto constituye vis, entonces la fractura propia del robo con fuerza en las cosas es tan constitutiva de crimen vis y rapinna como la coacción propia del robo. Por otra parte, en tanto descripción de una acción o actividad, la noción de violencia como acometimiento agresivo describe el despliegue de energía o incluso la disposición a ello, siendo irrelevante que esa energía agresiva se ejerza efectivamente afectando el cuerpo al que se encuentra dirigida. Esta concepción de la violencia hace ahora conceptual y sistemáticamente indistinguibles los casos de robo propiamente tal y de hurto con porte de armas. Si lo crucial para el concepto de violencia es la agresividad explícita o implícita en el comportamiento, entonces no es necesario que quienes sustraigan la cosa portando armas las usen

\footnotetext{
${ }^{14}$ Kuttner, Kanonistische Schuldlehre von Gratian bis auf die Dekretalen Gregors IX, 1935, p. 39 y ss., 299 y ss. El correlato de esta distinción en el Digesto se encuentra en la distinción entre vis y metus (Dig. 4, 2, 1), en la doctrina de Paulo sobre la subsistencia de la voluntad a pesar de la coacción intimidatoria (Dig. 4, 2, 21 \5) y en la distinción de Pomponio citada por Ulpiano entre la deyección mediante vis y la tradición mediante metus (Dig. 43, 16, 5).
} 
efectivamente, sino que basta que su porte vaya acompañado de su intención de usarlas en el caso en que se requiera.

La segunda postura coincide con el concepto moderno de robo en concebir la vis como coacción, pero discrepa radicalmente en su configuración. Mientras que el concepto de coacción que subyace a la moderna concepción del robo reúne la vis absoluta y la vis compulsiva, la postura en cuestión rechaza cualquier posibilidad de reunión de una y otra forma de coacción en un mismo concepto. Esta divergencia repercute directamente en la amplitud del tipo en relación con las formas concretas de apoderamiento. Para esta postura del derecho común, sólo puede ser considerado rapinna el apoderamiento constitutivo de un despojo de la posesión no consentido por el afectado. Cualquier forma de tradición de la cosa por su detentador -entrega, manifestación o aquiescencia a su apropiación-, caracterizada por la existencia de voluntad en el tradente -aún afectada por el temor-, quedaba conceptualmente excluida del ámbito de esta figura ${ }^{15}$.

Es interesante observar que una y otra postura se encuentran en los extremos metodológicos opuestos. La primera postura opta por elaborar un concepto amplio e indiferenciado de violencia, cuya función es la de servir de denominador común -carente de contenido propio en términos prácticos- a las distintas constelaciones de casos, legitimando con ello un tratamiento puramente exegético y casuístico de los textos autoritativos. La segunda postura, en cambio, parte de una distinción categorial irrefutable y de reconocida alcurnia filosófica ${ }^{16}$, subordinando el manejo interpretativo de los textos autoritativos a un sistema conceptual. Es en verdad un hecho notable de la historia de la dogmática jurídico-penal que el surgimiento del moderno concepto de robo haya tenido lugar apartándose de ambos extremos por igual.

El punto de partida de esta evolución conceptual es el rechazo efectuado por el célebre criminalista sajón del Siglo XVII, Benedict Carpzov, de la distinción filosófica como fundamento de la configuración del supuesto legal del robo. El problema práctico que Carpzov tenía delante suyo consistía en que los salteadores de caminos operaban "invitando" a sus víctimas a entregarles su bolsa si querían proseguir su viaje. La concepción filosófica de la coacción veía en la entrega de la bolsa un acto, si bien inducido por miedo, no obstante voluntario. Su traducción en términos jurídicos consistía en considerar dicho acto como una tradición de dinero, susceptible de ser revertida con consecuencias desfavorables para el adquirente bajo el régimen de la actio quod metus causa,

15 Este punto de vista, entendido como un sistema diferenciado de atribución de responsabilidad a la víctima por la disposición de la cosa, ha sido defendido por Hruschka como el único criterio sistemático coherente de tratamiento de los delitos de expropiación de cosas con apropiación correlativa, es decir, hurto, robo, extorsión de cosa y estafa de cosa (Das Opferverhalten als Schlüssel zum System der Sachentziebungsdelikte, en: Jahrbuch für Recht und Ethik 2 [1994], p. 177 y ss.). Este no es, sin embargo, el punto de vista del derecho penal continental. El rasgo central del tratamiento legal de la coacción es la diferenciación entre su función atributiva como fundamento del juicio (negativo) de imputación de responsabilidad al coaccionado y su función prescriptiva como fundamento del juicio de afirmación de la antijuricidad de la acción del coaccionador. La teoría del robo de Carpzov y Böhmer es uno de los hitos cruciales de la consagración de este trato diferenciado. Para el desarrollo de la distinción entre categorías prescriptivas y adscriptivas en la teoría del delito, Joachim Vogel, Norm und Pflicht. 1993, p. 28-29.

${ }^{16} \mathrm{La}$ tesis se remonta a la distinción de Aristóteles entre el involuntario y el voluntario mixto (Etica a Nicómaco, 1110 b), recogida por la teología moral escolástica (Tomás de Aquino, Suma Teológica, I-II, q.6 a. 4, 5 y 6) y también, aunque sobre otras bases, por el derecho natural racionalista (Hobbes, Leviathan, II, cap. 21; Tomasius, Fundamenta Iuris Naturae et Gentium, $4^{\mathrm{a}}$ ed., 1718, SS 68-70; Wolff, Grundsätre des Natur- und Völkerrechts, 1754, IS 3-5 y ss.). 
eventualmente susceptible de sanción penal bajo el delito de concussio, pero que como tal se encontraba excluida del ámbito de la actio bonorum raptorum y por lo mismo de la aplicación de la pena por el crimen vis. Para la elaboración dogmática del derecho común estatutario alemán (la Constitutio Criminalis Carolina u Ordenanza Judicial Penal de Carlos V), esto significaba que el hecho no podía ser sancionado como robo ("Raub": art. 126). Carpzov rechaza esta distinción en virtud de consideraciones de política criminal, sosteniendo que la coacción de la entrega de una cosa bajo amenaza constituye un atentado contra la paz pública tan relevante como el apoderamiento de la misma acompañado del vencimiento de la capacidad de oponer resistencia a ello ${ }^{17}$.

Como se puede apreciar, Carpzov concebía el problema como una distinción entre la entrega de la cosa a otro y la tolerancia de su apropiación por otro, es decir, como un problema referido al resultado de la coacción. No obstante, es evidente que su rechazo de la distinción tiene consecuencias para el tratamiento de los medios de coacción, desde el momento en que el resultado cuya calificación es objeto de disputa -el constreñir a entregar- sólo es susceptible de ser producido mediante el empleo de medios coercitivos que dejen subsistente la voluntad del coaccionado (vis compulsiva). Esta conclusión fue desarrollada con toda claridad por el célebre criminalista sajón del Siglo XVIII, Johann Samuel Friedrich Böhmer.

Con su justamente famosa definición de robo como "rei alienae mobilis animo lucri faciendi per vim personae illatam facta ablatio" 18 , Böhmer destacó la violencia en la persona (vis personae illata) como elemento esencial del tipo, logrando con ello su precisa delimitación frente al tipo de hurto y al tipo de la extorsión (concussio). La teoría de Böhmer del robo como coacción puede sintetizarse en tres tesis fundamentales:

1) La diferencia entre el robo y el hurto descansa en el uso de violencia en la persona como medio de apoderamiento de la cosa mueble ajena. Todos los supuestos en los cuales se usa de "fuerza en las cosas" (efracción, escalamiento, rotura de cerraduras o resguardos) constituyen a lo más casos agravados o calificados de hurto, pero se encuentran conceptualmente excluidos del ámbito del robo. Entre la "violencia en la persona" y la "violencia en las cosas", existe -sostiene Böhmer- una magna diferentia: mientras que la vis in rebus es effractura, rotura de dispositivos de resguardo, mediante la cual se roba, la vis in personam consiste en un impetu, es decir, en fuerza o coacción en la persona a quien se roba ${ }^{19}$. De aquí que, comentando a Carpzov, Böhmer sostenga que la violencia en las cosas propiamente dicho no suponga violencia o intimidación algunas ${ }^{20}$.

2) La concepción de la violencia en la persona como coacción se encuentra expresamente afirmada en la definición de vis que da Böhmer: "omne factum praesens, cui vel plane non, vel difficulter resisti potest" 21 . Esta definición afirma además la igualación, para efectos del tipo de robo, del vencimiento total y del vencimiento parcial de la resistencia

17 Carpzov, Practicae Novae Imperialis Saxonicae Rerum Criminalium, Pars II, Quaestio 90, 66-69 (11ª ed., 1723, p. 293).

18 "Sustracción de cosa mueble ajena hecha con ánimo de obtener lucro y mediante violencia en la persona": Meditationes in Costitutionem Criminalem Carolinam, 1770, art. 124, \ I, p. 517.

19 Op. cit., art. 126, \IV, p. 519.

20 Observationes Selectae ad Bened. Carpzovii JC. Practicam Novam Rerum Criminalium Imperialem Saxonicam, 1759, Observatio I ad. Q. 90 Num. 10, p. 77.

21 "Todo hecho presente que de plano no puede ser resistido o sólo puede serlo con dificultad": Meditationes...cit., art. 126 \ IV, p. 519. 
opuesta por el detentador de la cosa (o cuya oposición es esperada por el autor del robo). Con esta equiparación, Böhmer se enfrentaba deliberadamente a la distinción filosófica entre la coacción que deja subsistente la voluntad y la que la suprime. Siguiendo en este punto a Carpzov, Böhmer considera que la distinción filosófica es irrelevante desde un punto de vista práctico-jurídico; aduciendo que la ratio del Derecho penal se encuentra únicamente en la consideración de la securitatis publicae, Böhmer sostiene que el ejercicio de vis compulsiva merece la misma reacción punitiva que el ejercicio de vis absoluta. Digno de nota es que Böhmer aplica el argumento de Carpzov no para igualar comportamientos realizados bajo coacción (entregar o manifestar la cosa y tolerar su apropiación), sino derechamente para igualar formas o modos coacción.

3) La inclusión de la vis compulsiva en el ámbito del robo exigía naturalmente un replanteamiento de su demarcación frente al ámbito de la actio quod metus causa y del delito de concussionis, ya que la aplicación de la distinción filosófica quedaba descartada para estos efectos. En un primer momento, Böhmer acudió al criterio más apegado al tenor literal del Digesto, y sostuvo -junto con parte importante de la doctrina del derecho común- que la vis compulsiva propia de la concussio -excluida de la rapiña- era aquella que consistía en minae iuris, es decir, en la amenaza de hacer uso abusivo de una facultad o potestad 22. Posteriormente, Böhmer desarrolló un criterio demarcatorio basado en su misma concepción del robo como coacción, y sostuvo que la vis compulsiva propia del robo era aquella que consistía en la amenaza de irrogar inminentemente un mal ("propositione mali praesentis actuali" ${ }^{23}$. La razón de esta restricción al ámbito del robo la encontró Böhmer en su planteamiento político-criminal básico: puesto que quien es coaccionado bajo amenaza con irrogar un mal en el futuro puede acudir al Estado en busca de protección, no hay en este caso una afectación de la seguridad pública como la que supone el robo.

La influencia de la teoría de Böhmer en la doctrina del derecho común alemana fue enorme, creando con ello las bases doctrinarias del moderno concepto de robo que sería posteriormente recogido por la codificación. El nexo fundamental entre la doctrina y la legislación se encuentra en quien fuera asimismo el más influyente seguidor de la teoría del robo de Böhmer entre los autores del derecho común alemán de la primera mitad del Siglo XIX, Paul Johann Anselm Feuerbach. Desde la primera edición, en 1801, de su obra principal, el Tratado del derecho penal común vigente en Alemania, Feuerbach demuestra su adhesión a Böhmer concibiendo el robo como "sustracción mediante violencia en la persona del poseedor de la cosa", y entendiendo por una tal violencia la acción consistente en hacer mecánica o psicológicamente imposible al poseedor de la cosa oponerse a su sustracción ${ }^{24}$. Al concebir de este modo la violencia, Feuerbach reúne en un mismo concepto la vis absoluta y la vis compulsiva, entendidas ahora con suma precisión como el vencimiento de las fuerzas corporales del poseedor (vis absoluta) y el vencimiento de su voluntad mediante el insuflamiento de miedo a males (vis compulsiva). Tal como Böhmer, Feuerbach no exige requisitos especiales a la coacción constitutiva de vis absoluta para realizar el delito de robo, pero sí lo hace respecto de la coacción constitutiva de vis compulsiva. Ésta debe consistir en una coacción mediante amenaza de irrogar inminentemente un mal25. La razón que da Feuerbach para justificar esta restricción es una variación del argumento de Carpzov. A su juicio, una coacción mediante amenaza de un

22 Elementa Iurisprudentiae Criminalis, 1732, \135, p. 260).

${ }^{23}$ Meditationes...cit., art. 126, \ IV, p. 519.

${ }^{24}$ Lehrbuch des gemeinen in Deutschland geltenden Peinlichen Rechts, $1^{\mathrm{a}}$ ed. (1801), \396; $14^{\mathrm{a}}$ ed. (1847), \ 355.

25 Op. cit., loc. cit. 
mal de irrogación diferida en el tiempo, por permitir la protección del Estado, no puede ser considerada como medio determinante de la omisión por parte del poseedor de la cosa de oponer resistencia a su apropiación por parte del coaccionador ${ }^{26}$. Finalmente, cabe señalar que Feuerbach desarrolló el planteamiento de Böhmer en relación con un problema que se transformaría en una de las cuestiones prácticas más importantes de la codificación, cual es el de la relación que debe existir entre el ejercicio de la coacción y apropiación de la cosa. Apegándose a la noción del robo como apropiación coercitiva, Feuerbach sostuvo que lo que caracteriza el robo es que el acto de la sustracción sea realizado y hecho posible mediante la violencia. La coacción ejercida con posterioridad a la apropiación de la cosa, ya sea como defensa de la persona del delincuente o de la cosa hurtada no es constitutiva de robo sino de hurto con armas ${ }^{27}$.

Como se puede apreciar, la concepción moderna del robo es el resultado de la elaboración paulatina de la idea de violencia en la persona como el uso de una forma grave de coacción como medio de apropiación de una cosa mueble ajena. Esta idea surge primero con una equiparación de modos de ataque coercitivos (Carpzov), continúa con la distinción entre la violencia o intimidación gravemente coercitivas y otras formas de comportamiento violento o potencialmente agresivo pero no coercitivo, o formas menos graves de coacción mediante amenazas (Böhmer), para terminar en una aplicación estricta de la relación entre uso coercitivo de la violencia y la amenaza y la sustracción de la cosa (Feuerbach). En ninguna de las etapas de su evolución es posible encontrar, eso sí, una afirmación equivalente a la de Schünemann, en orden a definir al robo como delito compuesto de hurto y coacción $^{28}$. Eso se debe a que la concepción del robo como apoderamiento coercitivo surgió históricamente y se impuso en la doctrina con anterioridad a la consagración de la concepción de la coacción como un tipo de injusto autónomo ${ }^{29}$. De hecho, cabe afirmar que la teoría del robo (junto con la teoría de las agresiones sexuales como atentados contra la libertad) constituye el antecedente dogmático del posterior desarrollo político-criminal de la coacción como delito contra la libertad. Fue recién a mediados del Siglo XIX, una vez que ambas nociones se habían asentado en el sistema de la Parte Especial de la doctrina del derecho común y de la codificación de los estados particulares alemanes, que se consolidó el principio sistemático de la coacción-delito contra la libertad como tipo residual respecto del robo, y de éste -así

26 Ibídem, en la segunda nota al parágrafo respectivo.

27 Op. cit., $1^{\text {a }}$ ed. (1801), \ 397; $14^{\text {a }}$ ed. (1847), \ 356.

$28 \mathrm{Ni}$ siquiera Feuerbach, que sustituye el argumento de la afectación de la "seguridad pública" por una concepción funcional de la violencia y amenaza como medios de coacción, concibe el robo como una composición del tipo del hurto y el tipo de la coacción. La noción de coacción que Feuerbach maneja en los delitos de robo y violación se basa en su teoría de la coacción como causa de exculpación y fundamento de la atribución de responsabilidad al coaccionador (autoría mediata). Hasta la 12 a edición de su tratado (1825), Feuerbach desconocía la interpretación del crimen vis como coacción mediante violencia o amenaza, que se impuso a partir de entonces en la doctrina del derecho común alemán de la primera mitad del Siglo XIX (vid. la nota siguiente).

${ }^{29}$ La línea de la evolución del concepto de la coacción como delito es sinuosa. En términos generales, puede decirse que experimentó un importante desarrollo doctrinario a fines del Siglo XVIII (Grolman), y luego un fuerte retroceso a principios del Siglo XIX (Feuerbach); se mantuvo sin embargo en el plano de la política legislativa (proyectos de Tittmann, Erhard y Stübel para Sajonia, proyecto de von Weber para Württemberg), y desde finales de la segunda década del Siglo XIX se produjo su consagración definitiva en la doctrina y la legislación, hasta transformarse incluso en el concepto clave para la interpretación del crimen vis del derecho romano (Wächter). Sobre el surgimiento y desarrollo del delito de coacción en la doctrina y legislación alemanas puede verse mi artículo La regulación española de la coerción en el marco de la codificación penal europea, en: Anuario de Derecho Penal y Ciencias Penales, Tomo XLVIII (1994), p. 191 y ss. [esp. p. 218 y ss.]. 
como de la extorsión, la violación y los abusos sexuales- como tipo especial (calificado) de coacción.

\subsection{La regulación del robo en la codificación alemana, francesa y belga.}

Las variaciones que experimenta la regulación del robo en la codificación penal europea admiten ser explicadas aplicando como principio básico el grado de intensidad de la recepción de la teoría del robo del derecho común alemán, ya sea en su elaboración por Carpzov, por Böhmer o por Feuerbach ${ }^{30}$.

Naturalmente, la concepción del robo como apropiación coercitiva encontró su mayor recepción en la propia codificación alemana. La consagración legal de la teoría de Böhmer se debió fundamentalmente a la obra legislativa de Feuerbach, el Código Penal bávaro de 1813. Este texto legal configuró el tipo de robo en su art. 233 como la acción de hacer violencia a una persona, ya sea mediante maltrato o amenazas contra el cuerpo o la vida, para ejecutar una sustracción. Lo notable de esta técnica de tipificación es que pone el acento de lo injusto objetivo solamente en la coacción, transformando el delito de robo en un delito mutilado de dos actos desde el punto de vista de la apropiación y la lesión a la propiedad. Esta acentuación del carácter de coacción del robo experimentó su máxima expresión en la codificación sajona. En el Código Penal sajón de 1838, los delitos de robo y extorsión, también configurados como coacciones cometidas para obtener la apropiación o un provecho patrimonial, ni siquiera son sistemáticamente tratados como delitos contra la propiedad o el patrimonio, sino derechamente como delitos contra la libertad personal, junto a la privación de libertad, los atentados sexuales, la coacción y la amenaza (Parte Segunda, Capítulo VI, arts. 163-167). El Código Penal prusiano de 1851 mantuvo al robo y la extorsión dentro de los delitos contra la propiedad, y restableció la correlación entre el hurto y el robo exigiendo también respecto de este último la apropiación de la cosa para su consumación (\$230). En lo que respecta a su configuración precisa, la regulación prusiana recoge todos los elementos de la teoría de Böhmer, definiendo al robo como la conducta de sustraer una cosa mueble ajena con ánimo de apropiación mediante violencia en la persona o amenaza con peligro actual para el cuerpo o la vida. En la evolución experimentada por el delito de robo en la codificación alemana se produce no obstante una diferencia respecto del modelo doctrinario de Feuerbach. Para responder a las necesidades de la práctica judicial, la codificación alemana desarrolló junto al robo el supuesto del "hurto-robo" ("räuberischer DiebstabP"), destinado a sancionar con la misma pena del robo el caso en que la coacción mediante violencia en las personas o amenazas graves se comete con posterioridad a la apropiación ${ }^{31}$. Esta es, precisamente, la

\footnotetext{
30 Por supuesto, también desempeña un importante papel regulativo la existencia de la coacción como delito contra la libertad dentro del sistema de la Parte Especial y la precisión conceptual con que se la concibe. Esta es máxima en la codificación alemana y mínima en la codificación francesa (al respecto, La regulación española...cit.[nota 28], p. 204 y ss.).

31 Los distintos códigos penales alemanes diferían en aspectos de detalle sobre este punto. El Código Penal bávaro sancionaba con la misma pena del robo el hurto con porte de armas y uso efectivo posterior con el fin de "maltrato o intimidación" (art. 235 inciso primero) y el hurto con maltrato posterior cometido para asegurar la cosa (art. 235 inciso segundo); tratándose, en cambio del hurto seguido de una reacción defensiva del ladrón cometida para asegurar su persona, sólo cabía aplicar la pena por las lesiones u homicidio cometido en concurso con el hurto (art. 235 inciso tercero). El Código Penal sajón sólo extendía el carácter de robo al caso del ladrón sorprendido en la comisión del hurto que usa violencia o amenaza grave para conservar la tenencia de la cosa (art. 163). Finalmente, el Código Penal prusiano adhirió también a esta tipificación restrictiva de la codificación sajona, precisando que se trataba del participe en un hurto descubierto in fraganti (\$230 inciso segundo). Esta fórmula se consolidó en el Código Penal alemán de 1871 (\$252).
} 
regulación adoptada por el Código Penal alemán de 1871 (\$S 249, 252), vigente hasta el día de hoy.

El modelo regulativo opuesto al alemán es el de la codificación francesa ${ }^{32}$. El Código Penal de 1810 utiliza un solo concepto - "vol"33- para referirse a todos los delitos de apropiación de cosa mueble ajena, tratando a la apropiación con violencia o amenaza de uso de armas como una de las cinco hipótesis más calificadas de este delito, junto con las de comisión nocturna, de comisión por dos o más personas, de comisión portando armas y de comisión con efracción, escalamiento, llaves falsas o aparentando la condición de funcionario o autoridad pública ${ }^{34}$. La pena de la apropiación violenta o conminatoria depende de la concurrencia de las demás calificantes y del hecho de haber dejado huellas de heridas o contusiones. En cierto modo, la regulación francesa demuestra un principio de reconocimiento de una entidad propia de injusto a la apropiación violenta o conminatoria, que se expresa en la equiparación de su penalidad autónoma -es decir, de la pena aplicable aún cuando no concurra circunstancia adicional alguna- a la penalidad aplicable a la concurrencia de otras tres circunstancias (art. 385). Esta distinción expresa además la representación del legislador histórico, quien veía en la violencia "la circunstancia que más agrava el vol'35. No obstante esta relativa entidad autónoma de la apropiación violenta, en la regulación francesa es manifiesta la ausencia de una sistematización conceptual comparable a la teoría de Böhmer.

Precisamente es una sistematización de esa naturaleza lo que distingue al Código Penal belga de 1867 de su antecesor francés ${ }^{36}$. En este texto legal, los delitos de apropiación se encuentran sistematizados en un capítulo (Título IX, Capítulo I: "De los vols y de las extorsiones") dividido en cuatro secciones. La primera sección está dedicada a la definición de "vol" y a la regulación de la excusa legal absolutoria entre parientes (arts. 461-462); la segunda, a las apropiaciones cometidas sin violencias ni amenazas(arts. 463 a 467), dentro de las cuales se incluye casos calificados por la efracción y el escalamiento; la tercera sección comprende las apropiaciones cometidas con violencias o amenazas y las extorsiones (arts. 468 a 476), y la cuarta, reglas de definición de diversos términos (arts. 477 a 485), dentro de los cuales se encuentran los de "violencias" y "amenazas". Esta sistematización es consagrada por el legislador belga en deliberada contraposición a la regulación francesa y consciente recepción de la regulación alemana ${ }^{37}$. Si bien la

\footnotetext{
32 Sobre la regulación del Código Penal francés de 1810: Merlin, voz “Vol”, en: Répertoire Universel et Raisonné de Jurisprudence, $4^{\mathrm{a}}$ ed. (1815), Tomo XIV, p. 701 y ss.; Chauveau-Helie, Théorie du Code Pénal, $5^{\mathrm{a}}$ ed. (1872), Tomo V,p. 268 y ss.; Blanche, Études Pratiques sur le Code Pénal, Tomo V, 1870, p. 557.

33 El término francés "vol", definido por el Código Penal de 1810 como la acción de quien "ha sustraído fraudulentamente una cosa que no le pertenece" (art. 379), carece de traducción técnico-jurídica equivalente al idioma castellano. Su traducción más directa es el término "robo" tal como es usado en un sentido vulgar, es decir, comprensivo de toda apropiación de cosa mueble ajena. Así lo tradujo, por ejemplo, Manuel Carvallo en su versión castellana del Código Penal belga de 1867 (Santiago, Imprenta Nacional, 1868). Sin embargo, dado el uso deliberado que se hace aquí del término "robo" para designar sólo la apropiación coercitiva, para no incurrir en confusiones, se ha preferido mantener el término francés, o, cuando ello es posible traducirlo mediante el término neutral "apropiación(es)".

34 Este modelo regulativo procede en lo esencial del Código Penal de 1791 (Ley de 25 Septiembre - 6 Octubre, Segunda Parte, Título II, Sección Segunda).

35 Exposé des Motifs du Livre III, Titre II, Chapitre II, Présentés par MM. Le Chevalier Faure, et les Comtes Maret el Corvetto, Conseillers d'État, Sesión de 9 de Febrero de 1810, en: Code Pénal, édition conforme a l'édition originale du Bulletin des Lois, Paris, Imprimerie Stéreotype de Mame, Freres, 1811, p. 117.

${ }^{36}$ La historia fidedigna del establecimiento del Código Penal belga se encuentra en Nypels, Législation Criminelle de la Belgique, ou Commentaire et Complément du Code Pénal Belge, Tomo III, 1868, p. LIII y ss.; 475 y ss.

${ }^{37}$ Exposé des Motifs ou Rapport fait, au nom de la commission du gouvernement, par M-J.-J. Haus, et adressé á M. Le Ministre de la justice, $\mathrm{N}^{\circ}$ 2, en: Nypels, Legislation Criminelle...cit., p. 490.
} 
configuración del tipo de robo como la conducta de quien "haya cometido un vol mediante violencias o amenazas" (art. 468) no se aparta mayormente del modelo francés, sí lo hace la expresa equiparación al robo del supuesto consistente en el ejercicio de violencias o amenazas por quien es sorprendido en delito flagrante, ya sea para mantenerse en posesión de la cosa o para asegurar su fuga (art. 469). Esta disposición fue establecida inspirándose en la regulación prusiana ${ }^{38}$. La más extraordinaria muestra de recepción del concepto moderno de robo como coacción se encuentra sin embargo en la definición de los términos "violencias" y "amenazas" (art. 483). Esta fue una materia que dio lugar a disparidad de opiniones entre el Gobierno y la Cámara de Representantes, como lo demuestra la siguiente comparación de las respectivas disposiciones en uno y otro proyecto.

\section{PROYECTO GUBERNAMENTAL}

Art. 567. Por violencias la ley entiende los atentados dirigidos contra las personas y que consisten en golpear, herir, o matar.

Por amenazas la ley entiende las amenazas de emplear las violencias. ${ }^{39}$

\section{PROYECTO DE LA CAMARA DE REPRESENTANTES}

Art. 567. Por violencias la ley entiende los actos de constreñimiento físico ejercidos contra las personas.

Por amenazas la ley entiende todos los medios de constreñimiento moral por el temor de un mal inminente. ${ }^{40}$

La razón de la definición consignada en el Proyecto Gubernamental consistía fundamentalmente en la finalidad de restringir el ámbito del tipo de robo, excluyendo de él las simples vías de hecho, las violencias ligeras y todas las demás clases de amenazas ${ }^{41}$. Contra esta restricción reaccionó la Comisión de la Cámara de Representantes, por juzgarla excesiva. En el informe expuesto en la Sesión del 7 de Diciembre de 1860, Pirmez defendió la propuesta de la Comisión sosteniendo que ella respondía mejor a la naturaleza del delito en cuestión, que a su juicio difiere completamente de los demás casos de apropiación, incluso de aquellos cometidos atentando contra los resguardos adoptados por el propietario. En sus palabras:

"Pero en los casos en que el culpable ha usado de constreñimiento contra las personas mismas cuando la resistencia actual o posible puede obstaculizar sus proyectos, no sólo se añade al vol una infracción de una naturaleza enteramente distinta, sino que estas dos infracciones se unen, formando una nueva que comprende a una como medio y a la otra como fin, y que

\footnotetext{
${ }^{38}$ Nypels, op. cit., p. 494.

${ }^{39}$ Ibid., p. 477.

${ }^{40}$ Ibídem, p. 661. Las definiciones aprobadas por la Cámara de Representantes corresponden en lo esencial a la propuesta efectuada por la Comisión de dicha Cámara. La única diferencia se encuentra en el uso del adjetivo "inminente" en vez de "inmediato" para calificar el mal conminado (vid. Nypels, op. cit., p. 477, 583-585, 620).

${ }^{41}$ Exposé des Motifs...cit. [nota 34], N²3, en: Nypels, op. cit., p. 496.
} 
la experiencia prueba ser de las más peligrosas para el orden social." 42

La similitud de la concepción expuesta en este pasaje con la concepción del robo como coacción, en los términos expuestos por Schünemann en el pasaje arriba transcrito, es completa. Pirmez identifica en el constreñimiento ejercido para vencer la oposición actual o potencial de resistencia a la apropiación de la cosa, y no en la irrogación de lesiones corporales o la muerte, el elemento adicional de injusto de esta figura en relación a la simple sustracción de la cosa, considera este elemento adicional como una "infracción" de naturaleza diversa a la lesión de la propiedad, concibe al delito de apropiación con violencias o amenazas como un delito compuesto de dos infracciones distintas, y estima que la reunión de ambas infracciones potencia su gravedad. Por cierto, el paso que Pirmez no alcanza a dar para adherir enteramente al moderno concepto de robo es el de conceptualizar el constreñimiento como un atentado contra la libertad, en sí mismo constitutivo de delito: la coacción. Ello no es extraño, porque la noción de la coacción como un tipo de injusto autónomo es ajena al sistema de la Parte Especial del Código Penal belga, tal como lo era al sistema del Código Penal francés ${ }^{43}$. Con todo, en la discusión de la definición del término "amenazas" habida en la Cámara de Representantes se puede advertir nuevamente cuán nítida era la noción de vol cometido con amenazas como apropiación coercitiva manejada por el legislador belga. En esta ocasión, Pirmez sostiene que la finalidad de estas definiciones es la de determinar "los hechos que obligan a la víctima a ceder a los designios del agente"; continúa señalando que el "modo de coacción" mejor caracterizado es "el empleo de fuerza sobre la persona misma", y hace ver que tratándose del "constreñimiento moral" es necesario hacer una distinción, según si la irrogación del mal con que se amenaza se conmina para un tiempo inmediato o distante. Finalmente, reproduciendo de modo casi literal el argumento de Feuerbach, Pirmez sostiene:

"Cuando el mal no se producirá sino en un tiempo más o menos lejano, la persona amenazada tiene el medio de recurrir a la autoridad y de ponerse a resguardo. Su voluntad no está obligada a ceder por un constreñimiento mismo (sic). Ella no debe dar lugar sino a una penalidad menos grave, cual es la de la infracción de las amenazas." 44

Con esta afirmación, Pirmez demuestra entender no sólo al robo con amenazas como una forma calificada de apropiación coercitiva conminatoria, sino también a las amenazas condicionales como tipos de coacción menos grave mediante amenazas. Tomando en consideración que fue la regulación de la Cámara de Representantes la que en definitiva se impuso en esta materia, bien puede decirse de la regulación del robo en el Código Penal belga de 1867 que constituye el modelo regulativo más cercano a la concepción alemana del robo que cabe imaginar en el contexto cultural francés.

${ }^{42}$ Rapport fait, dans la seánce du 7 décembre 1860, au nom de la commission, par M. E. Pirmez, $\mathrm{N}^{\circ}$ 22, en: Nypels, op. cit., p. 543.

${ }^{43}$ En el modelo francés de regulación de la coacción -recepcionado en el Código Penal belga- sólo se sanciona la coacción bajo amenaza de un mal constitutivo de delito, supuesto sistemáticamente considerado como una hipótesis grave de amenazas, denominada "amenazas condicionales" o "amenazas imperativas" (arts. 305-308 C.P. francés, arts. 327-331 C.P. belga).

${ }^{44}$ Cámara de Representantes, Sesión de 8 de Marzo de 1861, en: Nypels, op. cit., p. 583 (las cursivas son del original). 


\subsection{La codificación española ${ }^{45}$}

En su erudito estudio sobre los conceptos de hurto y robo en el derecho romano, visigótico, castellano y español, Gonzalo Rodríguez Mourullo presenta un cuadro particularmente claro de la permanente oscilación que se produce en la cultura jurídica de España entre la recepción de la distinción romana entre furtum y rapinna y su pérdida y dilución en un concepto indiferenciado de robo. Tan interesante como esta conclusión, es el hecho que Rodríguez Mourullo vea en la distinción romana el equivalente a la moderna distinción entre hurto y robo. Desde el punto de vista de este autor, la diferencia entre uno y otro delito estaría en la constatación, por una parte, de un simple ataque a la propiedad (furtum, hurto), y por otra parte, de un ataque conjunto a la propiedad y la persona (rapinna, robo), como si el concepto de violencia en la persona no tuviera en sí mismo necesidad de ulterior análisis. No obstante esta insuficiencia dogmática, para nuestros propósitos es de interés su contraposición del romanismo de las Partidas con el vulgarismo de la legislación del antiguo régimen.

Conforme al conocido fragmento de la Partida Séptima ${ }^{46}$, "robo es una manera de malfetría que cae entre furto, e fuerça” ( 7,13 , pr.). La plástica expresión del texto refleja la dificultad inherente a la conceptualización del delito de rapinna del derecho romano, que las Partidas explícitamente identifican con el delito de robo $(7,13,1)$. Siendo claro que el elemento diferencial entre el simple hurto y el robo se encuentra en la fuerza ${ }^{47}$, la dificultad de precisar el concepto de robo se ve confirmada al comparar el tratamiento que se hace de los delitos contra la propiedad. Mientras que los delitos de hurto y daño son definidos por las Partidas hasta con refinamiento conceptual ${ }^{48}$, del robo apenas se señala que se hace en cosa mueble de otro. No menos vago es el concepto de fuerza, definido por la Partida Séptima como "cosa que es fecha a otro tortizieramente, de que non se puede amparar el que la recibe" $(7,10,1)$, y tratado como denominación común de una gran variedad de conductas, siguiendo de cerca el modelo de las leyes Julias sobre el crimen vis. En particular, es de interés en este contexto constatar que resulta constitutivo de fuerça el llevar consigo hombres armados para hacer mal o daño a otro, ya sea en su persona o en sus cosas $(7,10,1)$.

En este marco conceptual tan impreciso, no resulta sorprendente la circularidad ni la fungibilidad de las definiciones legales. Por una parte, la Partida Séptima define el robo como un delito compuesto de hurto y fuerza, y por la otra, en la enumeración de los casos de fuerza, menciona al propósito o la acción de robar como una de sus formas específicas. Tratándose de la apropiación de cosa mueble cometida con empleo de fuerza en las cosas,

45 Sobre la evolución de la regulación española del delito de robo: Pacheco, El Código Penal Concordado y Comentado, Tomo III, $3^{\mathrm{a}}$ ed. (1867), p. 280 y ss.; Groizard y Gómez de la Serna, El Código Penal de 1879 Concordado y Comentado, Tomo VI, 1896, p. 5 y ss.; Quintano Ripollés, Tratado de la Parte Especial del Derecho Penal, Tomo II, p. 33 y ss.; Rodríguez Mourullo, La distinción hurto-robo en el derecho bistórico español, en: Anuario de Historia del Derecho Español, XXXIII (1962), p. 25 y ss.

46 Citadas en adelante según la edición de Gregorio López, recogida en Los Códigos Españoles, Concordados y Anotados, Tomo IV, $2^{\mathrm{a}}$ ed., Madrid, 1872.

${ }^{47}$ Particularmente claro en este sentido es el siguiente pasaje de la Partida Primera, ubicado en el título relativo a los sacrilegios: "E diferencia ay en este furto, o robo; ea furto es, lo que toman a escuso, e robo es, lo que toman publicamente por fuerza" $(1,18,2)$.

48 "Furto es malfetria que fazen los omes que toman alguna cosa mueble agena, encubiertamente sin plazer de su señor, con intencion de ganar el señorio o la possession, o el vuso della" (7, 14, 1). "Daño es empeoramiento, o menoscabo, o destruymiento, que ome rescibe en si mesmo, o en sus cosas, por culpa de otro" $(7,15,1)$. 
por otra parte, la Partida Séptima considera esta acción como una de las tres maneras de robo $(7,13,1)$, y al mismo tiempo como un caso de hurto calificado $(7,14,18)$. Pero la más notable muestra de autorreferencia se encuentra en el hecho que en la configuración del caso más genérico de robo, este concepto es definido empleándose el mismo término a definir: "La segunda [manera de robo] es, quando alguno roba a otro lo suyo, o lo que lleuase ageno, en yermo, o en poblado, non auiendo razon derecha por que lo fazer" (7, $13,1)$.

A pesar de toda la imprecisión que afecta al concepto de robo, la regulación de las Partidas resulta un modelo de rigor conceptual comparada con la legislación del antiguo régimen, recogida en la Novísima Recopilación ${ }^{49}$. La pragmática de Felipe V, de 23 de Febrero de 1734, ordenó aplicar la pena capital a cualquiera que "le fuere probado haber robado á otro, ya sea entrando en las casas, ó acometiéndole en las calles y caminos, ya con armas ó sin ellas, solo ó acompañado, y aunque no se siga herida o muerte en la execución del delito" $(12,14,3)$. Aunque la aclaración añadida a la descripción de la conducta prohibida pareciera indicar que la prohibición se refiere a casos de apropiación con escalamiento o con violencia en las personas, lo cierto es que el mismo texto de la pragmática expresa que su finalidad es la de hacer frente a "la reiteración con que se cometen en mi Corte y caminos inmediatos y públicos a ella los delitos de hurtos y violencias". Y, ante la consulta acerca del alcance de la pragmática, formulada un año más tarde al propio rey a través del Consejo, Felipe $V$ no vacila en afirmar que ella se refiere "a todo hurto, calificado ó no, de poca ó mucha cantidad" $(12,14,5)$. Finalmente, ante la insistencia por morigerar el rigor de la sanción, Felipe V accede en 1745 a excluir del ámbito de aplicación de la pragmática a los "hurtos (...) simple de corta cantidad sin violencia ó fuerza, (...) sin escalamiento, herida, ni factura de puerta de casa, arca, cofre, papelera, escritorio ni otra cosa alguna cerrada en que estuviere la cosa que se hurtase, ni que se abriese con llave falsa, ganzúa ú otro instrumento semejante, ó que el robo llegase a la cantidad que fuese de mi Real agrado" $(12,14,6)$. En esta enumeración aparecen expresadas dos características incompatibles con la diferenciación conceptual entre hurto y robo desde el punto de vista del moderno concepto de robo. En primer lugar, el uso de violencia no es más que una circunstancia calificante del hurto, en un mismo plano que el escalamiento, la fractura de mecanismos de resguardo e incluso el monto considerable de la cosa. Esto se ve reafirmado por el segundo rasgo conceptual: incluso en el nivel lingüístico desaparece cualquier diferencia entre hurto y robo, como lo demuestra el uso de una y otra palabra como términos intercambiables. Esta indiferencia conceptual y fungibilidad terminológica de la legislación alcanza su máxima expresión en la cédula de Carlos III, de 17 de Octubre de 1769, que ordena castigar con pena de muerte "todo hurto, aunque sea el primero, cometido contra los colonos de las nuevas poblaciones con violencia en sus personas ó en sus casas", y con pena de azotes y arsenales a "el hurto de ganados, aún siendo el primero y sin violencia", y establece como prueba suficiente "la declaración del robado" $(12,15,11)$.

La doctrina española del Siglo XVIII y principios del Siglo XIX no se comportó de un modo sistemáticamente más riguroso que la legislación ${ }^{50}$. El autor que más

\footnotetext{
${ }^{49}$ Citada según su edición en Los Códigos Españoles...cit., Tomo X.

${ }^{50}$ La doctrina española más antigua, y más apegada al derecho común, conocía bien la doctrina de Carpzov y su recepción entre los juristas italianos, Clarus y Farinacius (así, Mattheu et Sanz, Tractatu de re criminali sive controversiarium, Ludguni, 1702, controversia XLIII, p. 343 y ss., especialmente la observación 9). Esta comunidad de ideas no se mantuvo sin embargo con el correr del Siglo XVIII, ni se produjo en España un
} 
nítidamente reconoció la diferencia conceptual entre el hurto y el robo, José Marcos Gutiérrez, no fue más allá de la formulación de las Partidas, y hasta desconoció la importancia de la distinción, haciendo ver que "lo cierto es, que por robar entendemos frecuentemente lo mismo que hurtar de cualquiera manera, y por robo lo mismo que hurto, como quiera que sea" 51 .

Con el advenimiento del Código Penal de 1822 se produce una ruptura radical con la tendencia legislativa y doctrinaria recién descrita. Aunque este texto contempla una profusa casuística, heredada del antiguo régimen, la combina con una diferenciación sistemática de un rigor conceptual inédito. Abandonando por completo la concepción indiferenciada del hurto y el robo, el Código Penal español de 1822 adopta como fundamento sistemático de la regulación de los delitos de apropiación la distinción conceptual entre robo y hurto atendiendo a los medios de la apropiación: si ella tiene lugar "con violencia o fuerza", se está en el ámbito de lo injusto del robo (arts. 723 a 744), y si, por el contrario, ella se realiza "fraudulentamente, sin fuerza ni violencia", se está en el ámbito de lo injusto del hurto (arts. 745 a 752).

En el ámbito del delito de robo, el Código Penal español de 1822 formula una nueva distinción, según si la fuerza o la violencia se hace "a las personas o a las cosas" (art. 724). Aunque el uso lingüístico del Código induce al error de considerar que esta distinción se basa únicamente en la identificación de objeto sobre el que se despliega la violencia, como si este último concepto se mantuviera en sí mismo inalterado en uno y otro caso, lo cierto es que las dos definiciones consignadas en el texto legal no dejan lugar a duda alguna de que se trata de dos conceptos de fuerza o violencia radicalmente distintos. Mientras que la "fuerza o violencia hecha a las personas" es coacción, la "fuerza o violencia hecha a las cosas" es el vencimiento de los mecanismos de resguardo de la esfera de custodia de las cosas.

El carácter coercitivo de la fuerza o violencia hecha a las personas queda de manifiesto con sólo leer la definición legal que consagra el Código Penal de 1822 en su art. 725:

"Son fuerza ó violencia hecha á la persona los malos tratamientos de obra, las amenazas, la orden de entregar ó manifestar las cosas, la prohibición de resistir o de oponerse á que se quiten, y cualquier acto que pueda naturalmente intimidar, ú obligar á la manifestación o entrega." 52

Es del mayor interés observar que en este contexto los términos "fuerza" y "violencia", no designan primariamente medios coercitivos específicos, sino la coacción misma, esto es, el constreñimiento del comportamiento ajeno, en este caso consistente en

desarrollo sistemático de las premisas de Carpzov equiparable al que se dio en Sajonia (vid. Rodríguez Mourullo, op. cit., p. 102 y ss.).

51 Práctica Criminal de España, Tomo III, Madrid, 1828, p. 81. Con anterioridad, de modo semejante a Gutiérrez, Senen Vilanova y Máñez, Materia criminal forense o Tratado universal teórico y práctico de los delitos y delincuentes en género y especie, Tomo III, Madrid, 1807, \XVII, p. 149 y ss.

52 Citado conforme a la reproducción fotostática de la edición de la Imprenta Nacional, Madrid, 1822, p. 147-148, en: Jacobo López Barja de Quiroga y otros, Códigos Penales Españoles, Madrid, 1988, p. 161-162. 
entregar o manifestar la cosa objeto de la apropiación o bien omitir la resistencia u oposición a ello. Esto no es de extrañar, porque corresponde a un sentido posible de los términos en cuestión, que bien puede ser además considerado como su sentido primario en el lenguaje corriente y que en todo caso lo fue en la historia de su uso ${ }^{53}$.

La definición del art. 725 del Código Penal español no cumple, pues, una función demarcatoria entre posibles modos o formas de coacción, dejando sólo algunos en el ámbito típico del robo. Las referencias que en este precepto se hace a los medios coercitivos específicos -maltrato de obra, amenazas, órdenes, prohibiciones, actos intimidatorios o compulsivos- se mueven en otro plano conceptual que el que corresponde a los términos "fuerza" y "violencia", y no tienen el carácter de una enumeración taxativa, sino meramente ejemplar de casos de aplicación del concepto de robo como apropiación con coacción.

Salvo por la consideración del vencimiento de los mecanismos de resguardo como elemento que da origen a un título de incriminación distinto del de hurto, la correspondencia entre las bases sistemáticas de la regulación del Código Penal español de 1822 y la teoría de Böhmer es manifiesta. Esta correspondencia resulta tanto más sorprendente cuando se tiene en cuenta la falta de desarrollo conceptual de la materia en la obra de los prácticos y doctrinarios españoles del Siglo XVIII y principios del Siglo XIX. El salto conceptual dado por el Código Penal de 1822 es incluso inusitado en comparación con los textos codificados que lo preceden inmediatamente en el ámbito cultural latino ${ }^{54}$. Sólo en el Código Penal bávaro de 1813 se encuentra una consagración semejante de la sistemática de Böhmer, pero no parece plausible conjeturar una recepción de su regulación en la codificación española. En contra de semejante hipótesis se encuentra, elocuente, el tratamiento dado por el Código Penal español de 1822 al uso de fuerza en las cosas, y, muy particularmente, al delito de extorsión ${ }^{55}$. Todo parece indicar

53 El término "coacción", que se ha impuesto en el uso especializado del lenguaje jurídico, es una palabra de reciente data en el idioma castellano. Hasta el Siglo XVIII, los términos castellanos para referirse a la coacción eran los de "fuerza" y "violencia". El primero deriva del término "força" (del latín fortia), que sustituyó al término latino "vis" en todos los romances de occidente (Joan Corominas, José A. Pascual, Diccionario Crítico Etimológico Castellano e Hispánico, 1984, Tomo II, p. 103, 972; Tomo IV, p. 823). La fecha convencionalmente asignada a la introducción del término "coacción" en el idioma castellano es el año 1729, que corresponde a la publicación del Tomo II de la edición del Siglo XVIII del Diccionario de la Lengua Castellana de la Real Academia Española (1726-1739), en el cual se señala que el término en cuestión "es voz puramente latina y de poco uso".

${ }^{54}$ Lo dicho es manifiesto respecto de la codificación francesa, ya examinada. En lo que se refiere al otro texto legal de importancia en el ámbito cultural latino, el Código Penal para el Reino de las Dos Sicilias de 1819, el contenido de injusto equivalente al robo es sistemáticamente considerado como un hurto calificado por la violencia, circunstancia ésta que comparte su función de calificante con las circunstancias de valor, persona, tiempo, lugar y medio (art. 407). Por otra parte, la violencia no es definida ni asumida genéricamente en este texto, sino tipificada en forma casuística, señalándose que la hay cuando el hurto va acompañado de homicidio, lesiones, heridas o secuestro de la persona, o de amenaza escrita o verbal de matar, herir o atentar contra las personas o propiedades, cuando un ladrón se presenta armado o más de uno se presentan conjuntamente, o cuando alguno que recorre armado los campos o que pertenece a una cuadrilla armada se hiciere entregar la cosa (art. 408). En esta regulación es evidente la pervivencia de la doctrina de la rapinna del derecho común anterior a Böhmer.

${ }^{55}$ El Código Penal bávaro de 1813 también sentó las bases de la regulación alemana del delito de extorsión, al considerarlo como una coacción patrimonial genérica y distinguir un tipo básico y uno calificado, según la gravedad de los medios coercitivos (arts. 241-243). El Código Penal español de 1822, por el contrario, prescindió de tipificar la extorsión como un delito contra la propiedad; en lugar de ello, configuró un sistema complejo de regulación de la coacción, donde se incluía un supuesto para la extorsión documental, agravándose la pena en caso de producirse daño patrimonial (art. 678). Detrás de esta regulación se encuentra, en parte, la influencia de la concepción francesa de la extorsión documental (art.400 C.P. francés 1810). 
que la teoría de los criminalistas sajones -junto con otras fuentes- influyó directamente en el proceso de génesis del Código Penal de 1822, por lo que su explicación y descripción permanecerán ocultas en tanto no se despeje la penumbra que aún rodea el surgimiento de este Código ${ }^{56}$. Mientras ello no suceda, sólo nos queda manifestar nuestro asombro ante un documento que por sus rasgos resulta único en su época y contexto cultural ${ }^{57}$.

Las bases sistemáticas del Código Penal de 1822 perduraron en la fase madura de la codificación española. Tanto el Código Penal de 1848 (arts. 415 a 428) como el Código Penal de 1850 (arts. 425 a 438) siguieron a su antecesor en la distinción entre robo y hurto, así como en la subdistinción entre robo con violencia en las personas y robo con fuerza en las cosas. Las definiciones legales de uno y otro concepto, sin embargo, desaparecieron, dando lugar a una nueva terminología. Los textos de 1848 y 1850 ya no emplean los mismos términos - "fuerza o violencia"- para referirse por igual a las acciones de la coacción y el vencimiento de mecanismos de resguardo, sino que ahora se distingue entre la "violencia o intimidación en las personas" (coacción) y la "fuerza en las cosas" (vencimiento de mecanismos de resguardo). Por otra parte, la relevancia típica de una y otra fórmula lingüística pasa a ser muy diversa. La fórmula expresiva de la coacción constituye directamente un elemento del tipo del delito de robo, sin recibir ulterior concreción o precisión en el texto legal. Por el contrario, la fórmula expresiva del vencimiento de los mecanismos de resguardo no integra como tal el tipo del delito de robo, sino que tiene una función meramente sistemática o terminológica, consistente en servir de denominación común para todas las hipótesis de apoderamiento con vencimiento de mecanismos de resguardo, concretamente configuradas mediante la precisión de cada forma de vencimiento de dichos mecanismos (escalamiento, fractura exterior e interior, uso de instrumentos, seducción, simulación).

Estos son los rasgos esenciales de la regulación española hasta el día de hoy ${ }^{58}$.

\subsection{La regulación del robo en el Código Penal chileno}

\section{a. La Ley general de burtos y robos de 7 de Agosto de 1849.}

La regulación del delito de robo en el derecho aplicable en Chile antes de la instauración de la República y en los primeros tiempos de ésta no difería de la regulación

\footnotetext{
$56 \mathrm{Al}$ respecto, José Antón Oneca, Historia del Código penal de 1822, en: Anuario de Derecho Penal y Ciencias Penales, Tomo XVIII (1965), p. 263 y ss.; José Ramón Casabó Ruiz, La aplicación del Código penal de 1822, en: Anuario de Derecho Penal y Ciencias Penales, Tomo XXXIII (1979), p. 333 y ss.

${ }^{57}$ Una conclusión muy semejante es la que se obtiene cuando se analiza la regulación que el Código Penal de 1822 hace de lo injusto de la coacción: ésta consiste en una combinación de la codificación francesa con la antigua regulación española, pero sobre una base conceptual y bajo principios sistemáticos completamente inéditos (al respecto, La regulación española de la coerción...cit. [nota 29], p. 265 y ss.).

${ }^{58}$ Con una importante modificación introducida por el Código Penal de 1870, que implica un retroceso en la diferenciación entre el apoderamiento coercitivo y el apoderamiento con vencimiento de los mecanismos de resguardo. Este texto legal reunió nuevamente ambas clases de robo en un mismo apartado (Capítulo I del Título XIII del Libro Segundo: arts. 515 a 529), subsumiéndolas en un concepto genérico de robo, opuesto al de hurto (Capítulo II: arts. 530 a 533). El nuevo concepto de robo no dejó, sin embargo, lugar a dudas respecto de su duplicidad: "Son reos del delito de robo los que, con ánimo de lucrarse, se apoderan de las cosas muebles ajenas, con violencia o intimidación en las personas ó empleando fuerza en las cosas" (art. 515). Esta sistematización perduró en los Códigos de 1932 y 1944, y ha sido mantenida por el nuevo Código Penal de 1995.
} 
española ${ }^{59}$. Esta situación experimentó una transformación profunda con la dictación de la Ley de 7 de Agosto de 1849, fuertemente influida por el Código Penal español de 1822.

Notablemente, la legislación chilena fue más allá que su modelo español en la consagración de la distinción sistemática fundamental entre robo y hurto. La "fuerza o violencia en las cosas" deja aquí de constituir una especie de robo, para pasar a constituir un supuesto calificado de hurto (arts. $8^{\circ}$ y $9^{\circ}$ ). De este modo, la distinción entre hurto y robo pasa a ser una distinción entre el apoderamiento de cosa mueble ajena cometido "fraudulentamente" (art. $1^{\circ}$ ) y el cometido "con violencia o fuerza hecha a la persona" (art. $11^{\circ}$ ). La recepción así modificada de la codificación española implica, como es evidente, un acercamiento aún más intenso al modelo conceptual de Carpzov, Böhmer y Feuerbach. Este acercamiento corresponde también a las representaciones del legislador histórico. En los antecedentes fidedignos de la historia de su establecimiento hay suficiente constancia acerca de la formulación de una diferencia categorial, al menos por parte de algunos integrantes de la Cámara de Diputados, entre la apropiación con fuerza en las cosas, constitutiva de una mera circunstancia calificante del hurto, y la apropiación con violencia en las personas, constitutiva de un tipo de injusto de naturaleza más compleja y grave que el hurto ${ }^{60}$. La consistencia específica de la naturaleza compleja del robo no es algo que reciba una precisión conceptual enteramente satisfactoria en las representaciones del legislador histórico. En todo caso, de la discusión mantenida por Montt y García Reyes en torno al régimen de agravación de la pena del robo por el resultado puede al menos deducirse que la Cámara de Diputados optó por una regulación basada en tres consideraciones fundamentales: (a) que en el robo, además del ataque a la propiedad de la cosa se da un ultraje o injuria personal, (b) que ese ultraje o injuria no tiene significación autónoma sino subordinada a la apropiación, como medio al fin, y (c) que la relevancia típica de este ultraje o injuria personal en el ámbito del robo, al menos en su umbral básico de punición, es independiente de su relevancia como delito de lesiones o maltrato de obra. En este contexto, por cierto, los términos "ultraje" o "injuria" no son utilizados en su sentido estricto de afrenta al honor ajeno, sino en su sentido más amplio, como acto antijurídico contra la persona ${ }^{61}$. Este es el mayor grado de precisión con que puede referirse a la coacción una cultura jurídica que desconoce su condición de tipo de injusto.

En lo que respecta a la definición de la forma de apoderamiento de la cosa mueble constitutiva de robo, se trata de una trascripción de la respectiva disposición española, con una redacción mejorada:

\footnotetext{
59 Al respecto: Alamiro de Ávila Martel, Esquema del Derecho penal indiano, 1941, p. 86 y ss; Oriana Valladares Assmunsen, Alicia Núñez Vargas, Jurisprudencia penal indiana: Delitos contra la propiedad, Santiago, 1961, p. 7-8; Jorge Cortés del Fierro, Derecho penal patrio y su jurisprudencia en la República de Chile entre los años 1817 y 1876: El delito de salteo, Santiago, 1962, p. 4 y ss.

60 Sesiones del Congreso Nacional de 1848, Cámara de Diputados, Sesión 26 en 14 de Agosto de 1848, y Sesión 27 en 16 de Agosto de 1848.

${ }^{61}$ Es decir, no en el sentido específicamente penal (art. 416 C.P.), sino en el sentido genérico del derecho privado (art. 44 inciso final del Código Civil). Este uso del término "injuria" es constatable incluso en los trabajos preparatorios del Código Penal chileno. En la Sesión 145 de la Comisión Redactora, habida el 29 de Mayo de 1873, se acordó eliminar del actual art. 138 C.P. la hipótesis de obligar al ejercicio de un culto, dejando sólo la de impedirlo, fundándose ello en la consideración de dicho caso, de realizarse, "no importaría otra cosa que una injuria privada" (Actas .... cit. [infra, nota 63], p. 509).
} 
"Art. 11. Son violencia o fuerza hecha a la persona, los malos tratamientos de obra, las amenazas, ya para hacer que se entreguen o manifiesten las cosas, ya para impedir la resistencia u oposición a que se quiten, o cualquier acto que pueda intimidar o forzar a la manifestación o entrega." 62

En esta redacción, los sustantivos "orden de entregar o manifestar" y "prohibición de resistir u oponerse", propios de la fórmula española, han sido sustituidos por los verbos "hacer que se entreguen o manifiesten", "impedir la resistencia u oposición". Con ello se suprime su falsa apariencia de medios coercitivos específicos, distintos de los malos tratamientos de obra o las amenazas, aclarándose totalmente su condición de representación de un resultado coercitivo, que en el plano subjetivo ("para hacer", "para impedir") corresponde al fin perseguido con el uso del maltrato de obra, la amenaza o cualquier otro acto intimidatorio o coercitivo. La redacción chilena de esta definición confirma plenamente el sentido que tenía la fórmula legal del Código Penal español de 1822, conforme a lo dicho arriba.

\section{b. La labor de la Comisión Redactora del Código Penal.}

En lo esencial, la regulación del delito de robo en el texto originario del Código Penal chileno (1874) fue determinada por la Comisión Redactora en sus sesiones 90, 91, 92 y 93 (en 3, 5, 7 y 12 de Junio de 1872), sobre la base de un proyecto de redacción preparado por don Manuel Rengifo, como era habitual ${ }^{63}$. De los dos textos legales adoptados por regla general por la Comisión como sus fuentes -el Código Penal belga de 1867 y el Código Penal español de 1850-, el predominio de la influencia del texto español en el texto acordado por la Comisión es manifiesto. Esto no es más que la prolongación de la recepción de la codificación española en la legislación chilena, ya producida con ocasión de la dictación de la Ley general sobre hurtos y robos de 7 de Agosto de 1849, que también sirvió de base para la redacción del texto del Código Penal.

La influencia del Código Penal español de 1850 produjo sus mayores efectos en el tratamiento de la apropiación con fuerza en las cosas. De ser un caso de hurto agravado, como lo era en la legislación patria, paso a configurar el delito de robo con fuerza en las cosas, conceptual y sistemáticamente diferenciado tanto del hurto como el robo con violencia o intimidación en las personas. Esta alteración de la regulación hasta ese entonces vigente corresponde a una decisión sistemática deliberada del legislador. En la Sesión 90 de la Comisión Redactora, habida el 3 de Junio de 1872, don Manuel Rengifo dio cuenta de la diferencia de trato sistemático existente entre la ley patria y el Código español, pronunciándose a favor de éste último, por estimar que su regulación se encuentra "más conforme con el sentido jurídico de las palabras hurto y robo"64. Frente a esta situación, la Comisión Redactora adoptó cinco acuerdos que consagraron las bases sistemáticas de la regulación de los delitos de hurto y robo en el Código Penal chileno, optándose por distinguir tajantemente entre hurto y robo al modo español.

\footnotetext{
${ }^{62}$ Citado conforme al texto reproducido en el Boletín de las Leyes, Volumen 17 (1849), p. 136 y ss. [139].

${ }^{63}$ Se las cita conforme a la trascripción de las actas de las sesiones de la Comisión Redactora en la edición crítica del Código Penal de la República de Chile y Actas de las Sesiones de la Comisión Redactora del Código Penal Chileno, preparada bajo la dirección de Manuel de Rivacoba y Rivacoba, Valparaíso, 1974, p. 418 y ss.

${ }^{64}$ Actas...cit., p. 417.
} 
Concretando esta decisión, Manuel Rengifo esbozó un plan sistemático en el que las distinciones conceptuales proceden del siguiente modo. El primer apartado sistemático contiene una definición general, que formula la base de la sistematización subsecuente. En esta definición existe un género - "apropiarse de cosa mueble ajena sin la voluntad de su dueño y con ánimo de lucro"- y dos especies, una de las cuales -el robo- se define positivamente por la posesión de atributos específicos - "usando de violencia o intimidación en las personas o de fuerza en las cosas"-, mientras que la otra especie -el hurto- recibe una definición puramente negativa, consistente en la carencia de esos atributos específicos. Este enunciado inicial que formula las bases conceptuales de la sistematización legal es una contribución original de Manuel Rengifo, con base en la regulación del Código Penal belga de 186765.

El concepto de robo recibe, tal como en la codificación española, una nueva distinción, utilizándose como criterio clasificatorio las mismas propiedades que lo distinguían específicamente del concepto de hurto. Siguiendo también la sistematización de la codificación española, el proyecto de Manuel Rengifo regula primero el robo con violencia e intimidación en las personas, y posteriormente el robo con fuerza en las cosas. La regulación del robo con violencia e intimidación en las personas sigue el esquema del Código Penal español, tipificando primero las hipótesis calificadas de robo $^{66}$, y después la hipótesis residual o genérica ${ }^{67}$. Apartándose del Código Penal español de 1850 para volver el Código de 1822, el proyecto de Rengifo cierra el apartado sistemático del robo con violencia o intimidación en las personas con la definición de estos términos en la redacción de la Ley general de hurtos y robos de $1849^{68}$.

Como se puede apreciar, la regulación acordada por la Comisión Redactora se mantiene apegada al modelo regulativo español, combinando rasgos que en su gran mayoría son propios del Código Penal de 1850 con algunos remanentes del Código de 1822, recepcionados previamente a través de la legislación patria. Salvo por la introducción del concepto de robo con fuerza en las cosas, la síntesis entre los Códigos de 1822 y 1850, lograda con la intermediación de la ley patria, hace del Código Penal chileno un texto que inequívocamente recoge y consagra el concepto moderno del robo como coacción.

Hay un aspecto en que el texto aprobado por la Comisión Redactora introduce, eso sí, una variación importante en relación con las fuentes españolas. Al tipificar las hipótesis graves o calificadas de robo, el proyecto de Rengifo consagra una fórmula regulativa referida al momento u oportunidad del uso de violencia o intimidación en las personas, expresando al menos respecto de las hipótesis de robo calificado, que es igualmente constitutivo de robo...

\footnotetext{
${ }^{65}$ No así las definiciones mismas, que proceden tanto del Código Penal español de 1850 (arts. 425 y $437 \mathrm{~N}^{\circ}$ 1), como de la Ley general de hurtos y robos de 1849 (arts. $1^{\circ}, 8^{\circ}$ y 11 ).

66 Arts. 420 y 421 del proyecto, equivalentes a los arts. 433 y 435 del texto originario del Código Penal (Sesión 92, en 7 de Junio de 1872, en: Actas...cit., p. 419-420).

${ }^{67}$ Art. 422 del proyecto, equivalente al art. 436 del texto originario del Código Penal (Sesión 93 en 12 de Junio de 1872, en: Actas...cit., p. 421).

68 Art. 426 del proyecto, equivalente al art. 439 del texto originario del Código Penal (Sesión 93 en 12 de Junio de 1872, en: Actas...cit., p. 422).
} 
“...que la violencia o intimidación tenga lugar antes del robo para facilitar su ejecución, en el acto de cometerlo o después de cometido para favorecer su impunidad..."69.

Esta fórmula aclaratoria de la extensión del ámbito típico del robo respecto de las posibles formas de relación entre el ejercicio de coacción y el apoderamiento de la cosa mueble ajena no se encuentra en el Código Penal español de $1850^{70}$, ni hay constancia acerca de su origen en las Actas de las Sesiones de la Comisión Redactora. Este pareciera no obstante encontrarse en un intento de síntesis del art. 38 de la Ley de 7 de Agosto de 1849 con otras fuentes de la codificación europea ${ }^{71}$. De la disposición patria proviene la redacción del precepto $^{72}$. La influencia de la codificación europea se aprecia fundamentalmente en la aplicación de esta concepción extensiva solamente al robo con violencia o intimidación en las personas.

Con este añadido quedó consolidada la recepción del modelo regulativo español en la codificación penal chilena.

\section{c. Las reformas posteriores.}

Las disposiciones sobre los delitos de hurto y robo han sido una de las materias del Código Penal chileno que más modificaciones legales ha experimentado. Desde la Ley de 5 de Octubre de 1876, que estableció la pena de azotes para los condenados por hurto o robo y la pena de muerte para el robo calificado, hasta la Ley 19.501, de 15 de Mayo de 1997, que estableció una nueva escala de penalidades para el delito de hurto, las disposiciones comprendidas en los arts. 432 a 456 bis han sido modificadas en cerca de quince oportunidades. De todas estas modificaciones, la más importante en relación con el

${ }^{69}$ Art. 420 del proyecto, equivalente al art. 433 del texto originario del Código Penal (Sesión 92, en 7 de Junio de 1872, en: Actas...cit., p. 420).

${ }^{70}$ En la codificación española sólo puede citarse como antecedente de esta disposición el art. 611 del Código Penal de 1822, que en su primera parte es del siguiente tenor: "Los salteadores y ladrones que de cualquier modo maten para robar ó hurtar, ó en el acto de hacer el robo ó hurto, ó después para encubrirlo ó salvarse, serán castigados como asesinos". Se trata pues, de una regla que configura un supuesto de homicidio calificado, lo cual transforma por completo las relaciones entre el homicidio y la apropiación, como más adelante se verá.

${ }^{71}$ La principal de estas fuentes es el art. 469 del Código Penal belga de 1867, que adoptó la evolución experimentada por la regulación del robo en la codificación prusiana, como arriba se expuso. Eduardo Quezada Roldán (El delito de robo con homicidio, Santiago, 1946, p. 35), ha llamado la atención acerca de la similitud existente entre el texto legal chileno y el inciso final del art. 408 del Código Penal del Reino de las Dos Sicilias de 1819, sosteniendo que este texto pudo haber servido de fuente material a la Comisión Redactora del Código Penal chileno a través de las concordancias de Joaquín Francisco Pacheco. Al menos a primera vista, la semejanza entre ambos textos es ciertamente sorprendente. La primera parte del inciso final del art. 408 C.P. napolitano es del siguiente tenor: "Para que un acto de violencia califique el hurto, basta con que sea cometido anterior o contemporáneamente al hurto, o también inmediatamente después, con el objeto de facilitar la consumación o la impunidad...”. En su traducción por Pacheco, la similitud del fragmento es aún mayor: "Para que un acto de violencia constituya el robo en la categoría de cualificado, basta con que se hubiere ejercido antes del robo, durante él o inmediatamente después de él, con ánimo de facilitar su ejecución ó conseguir su impunidad..." (El Código Penal, Concordado y Comentado, Tomo III, $3^{\mathrm{a}}$ ed., 1867, p. 288). Para que este antecedente tenga peso específico en la elaboración dogmática del art. 433 es necesario, sin embargo, demostrar que el Código Penal napolitano influyó en el proceso de formación de la Ley de 7 de Agosto de 1849 (vid. la nota siguiente).

72 Art. 38 de la Ley de 7 de Agosto de 1849: "La violencia o fuerza a la persona o cosa, que según esta lei acarrea agravación de pena, basta que sea ejecutada antes del hurto o robo, para facilitar su ejecución, en el acto de cometerlo, o después de cometido para favorecer su impunidad”. 
delito de robo con violencia o intimidación en las personas ha sido sin duda la efectuada por la Ley 11.625, de 4 de Octubre de 1954.

Esta ley estableció una nueva regulación de las hipótesis calificadas o agravadas de robo, simplificando la detallada regulación originaria del Código Penal, que contemplaba cuatro numerandos en el art. 433 y dos incisos en el art. 435, aumentando además las penalidades. La configuración del tipo objetivo de las hipótesis calificadas o agravadas introducida por la Ley 11.625, cuyas innovaciones fueron más bien de redacción que sustanciales, perdura hasta el día de hoy. Las penalidades de dichas hipótesis, así como la configuración del tipo subjetivo, han sufrido sin embargo modificaciones posteriores ${ }^{73}$.

La misma operación de simplificación de hipótesis y aumento de penalidades experimentó el tipo residual o genérico de robo. El texto originario del Código Penal establecía tres marcos penales diferentes de presidio (tres años y un día a diez años, quinientos cuarenta días a cinco años, sesenta y un días a tres años) atendiendo al valor de la cosa objeto del robo. La Ley 11.625 estableció en su lugar una pena única de cinco años y un día a veinte años de presidio, cualquiera que fuera el valor de la cosa objeto de robo. Esta disposición (art. 436 inciso primero), no ha experimentado modificaciones posteriores. En lo que respecta a la configuración del tipo genérico o residual de robo (arts. 432, 436 inciso primero y 439), la Ley 11.625 no introdujo modificación alguna.

De lo dicho se concluye que el objetivo político-criminal de la Ley 11.625 consistió en aumentar la penalidad del delito de robo y al mismo tiempo simplificar el régimen legal de determinación de dicha penalidad. En particular, es importante constatar que la modificación de la penalidad del tipo básico de robo no respondió a una nueva concepción de este delito que supusiera en su comisión la concurrencia de circunstancias o la reunión de elementos distintos y adicionales a los exigidos por la regulación originaria del Código. Tal como puede verse en las monografías de fecha más cercana a la dictación de la Ley $11.625^{74}$, la reforma introducida por esta ley consistió en establecer una consecuencia jurídica considerablemente más severa a la realización de la misma conducta descrita desde 1849 por la ley como robo con violencia (o fuerza) o intimidación en las personas.

Por lo demás, la decisión de prescindir del valor de la cosa para determinar la pena aplicable al robo no constituyó una innovación radical en el plano de la política criminal chilena. Ya en 1848 había propuesto Manuel Montt desde la Presidencia de la Cámara de Diputados que no se aplicara al robo el criterio de determinación de la pena del hurto $^{75}$, tesis ésta que posteriormente adoptó la Comisión Redactora del Código Penal como uno de sus principios básicos de la regulación de los delitos de hurto y robo ${ }^{76}$. Es decir, con esta modificación, la Ley 11.625 no hizo sino consagrar una propuesta legislativa defendida en Chile desde los mismos orígenes de la regulación del robo.

\footnotetext{
${ }^{73}$ Leyes 13.303, de 31 de Marzo de 1959, y 19.029, de 23 de Enero de 1991.

${ }^{74}$ Sergio Soto Reveco, El delito de robo con violencia o intimidación en las personas, Santiago, 1958, p. 75 y ss.; María Morales Concha, El robo con violencias o intimidación en las personas, Concepción, 1974, p. 103 y ss.

75 Sesión 26, en 14 de Agosto de 1848 (Sesiones del Congreso Nacional de 1848, No 26, p. 213); Sesión 27, en 16 de Agosto de 1848 (Sesiones...cit., p. 218-219).

76 Sesión 90, en 3 de Junio de 1872, en: Actas...cit., p. 418.
} 
Eso sí, esta opción legislativa hace aún más urgente la necesidad de contar con una concepción bien fundada de la estructura de injusto del robo, precisamente en lo que tiene de distinto al hurto. Pues, tal como se señalara en el mensaje del proyecto de ley que dio lugar a la Ley 11.625, si algún fundamento político-criminal tiene el cambio de criterio de determinación de la penalidad del robo, él se encuentra en la asignación de un peso específico de injusto particularmente relevante al empleo de violencia o intimidación en la persona $^{77}$.

\section{Consecuencias dogmáticas.}

Lo expuesto en la sección anterior permite sostener que la legislación penal chilena consagró durante el Siglo XIX la configuración del delito de robo como un tipo compuesto de los injustos típicos del hurto y la coacción. Es decir, que en la codificación chilena se produjo el mismo fenómeno histórico acaecido en la codificación española y en la codificación belga, consistente en la recepción de la moderna concepción del robo como coacción.

Partiendo de esta base histórico-dogmática, es posible reconstruir racionalmente lo dispuesto en los arts. 432, 436 inciso primero y 439 del Código Penal, y de este modo sostener que el tipo básico del delito de robo consiste en apropiarse de cosa mueble ajena sin la voluntad de su dueño constriñendo a otro mediante violencia o intimidación a entregar o manifestar la cosa, o a omitir la resistencia u oposición a la apropiación ${ }^{78}$.

La definición de este modo del tipo básico del delito de robo constituye el núcleo duro de un auténtico programa de investigación dogmática ${ }^{79}$, cuya implementación arroja consecuencias para el planteamiento y solución de las diversas cuestiones interpretativas que plantea la regulación legal chilena. A modo de ejemplificación de lo anterior, a continuación se pasará una breve revista a seis aspectos problemáticos: (1) la ampliación del ámbito típico del robo más allá de la acción de apropiación stricto sensu, (2) la relación final entre el ejercicio de violencia o intimidación y la apropiación, (3) la relación temporal entre el ejercicio de violencia o intimidación y la apropiación, (4) la relación sistemática entre el tipo básico y los tipos calificados de robo, (5) la relación entre el robo y el así denominado "robo por sorpresa", y (6) la relación entre el robo y la autotutela ilícita.

\subsection{Robo y extorsión}

La concepción de la acción de apropiarse es una cuestión crucial para la construcción del concepto del delito de robo. Para efectos de nuestro análisis se asumirá que en el contexto del art. 432 la acción de apropiación consiste en la arrogación del poder

77 En palabras del mensaje del Presidente González Videla: “el núcleo principal de la figura está en la violencia o intimidación ejercida sobre la víctima, a veces para sustraerle dinero o especies cuyo monto o valor se desconocen" (Cámara de Diputados, Sesión 58ª ordinaria, en 12 de Septiembre de 1951, Sección IV, N 1, p. 2861).

${ }^{78} \mathrm{La}$ regla del art. 433 inciso primero no forma parte de la definición del tipo de robo. Sobre esto se volverá luego, cuando se examine el problema de la relación temporal entre el ejercicio de violencia o intimidación y la apropiación.

${ }^{79}$ Uso el término "programa de investigación dogmática" en analogía lo más estrecha posible a la teoría de los programas de investigación científica de Imre Lakatos (Falsification and the Methodology of Scientific Research Programmes, en: Imre Lakatos, Allan Musgrave, Criticism and the Growth of Knowledge, 1989, p. 91 y ss.; del mismo: Historia de la ciencia y sus reconstrucciones racionales, Madrid, 1982, p. 11 y ss. ). 
fáctico inherente a la posición jurídico-formal de propietario sobre una cosa mueble ajena, cometida mediante la ruptura de la custodia preexistente y la constitución de una nueva custodia, todo ello con un ánimo de apropiación ${ }^{80}$. Partiendo de esta premisa, cabe constatar que la estructura típica del delito de robo, tal como se encuentra configurado en el Código Penal chileno, evidencia una notable peculiaridad o anomalía: no es exclusivamente un delito de apropiación, como el hurto o el robo con fuerza en las cosas, sino también un delito de recepción de la cosa mueble ajena.

En el Código Penal chileno no sólo la acción de constreñir a tolerar la apropiación es constitutiva de robo, sino también las acciones de constreñir a entregar o a manifestar la cosa sobre la que se constituirá una nueva custodia. Es decir, el robo no supone necesariamente la ruptura de la custodia requerida por la apropiación en el sentido del delito de hurto (sustraer, apoderarse, quitar, tomar), sino que admite también la entrega o transferencia de la esfera de custodia por parte del propietario, poseedor o tenedor de la cosa. Desde la perspectiva del derecho comparado, esta particularidad de la regulación legal chilena, que es indesmentible a la vista del art. 439 C.P., extiende el ámbito típico paradigmático del delito de robo hacia el ámbito típico del delito de extorsión, en su variante concreta de extorsión-de-cosa ${ }^{81}$.

Por cierto que la disposición o entrega de la esfera de custodia sobre la cosa objeto del delito se encuentra afectada como acto jurídico por el vicio de la fuerza (art. 1546 Código Civil), y que en tal carácter debe ser considerada al menos como anulable relativamente (arts. 1681 y ss. Código Civil). Ello no altera, sin embargo, que en este caso es típica en el sentido del art. 432 una apropiación lograda con la contribución consciente del propietario, poseedor o tenedor de la cosa, lo que hace una gran diferencia en relación con la apropiación obtenida mediante la inducción por engaño a la disposición o entrega de la custodia sobre la cosa. En este último caso, sólo si el engaño produce un error que recae sobre la pérdida de la esfera de custodia hay apropiación en el sentido del art. 432. De lo contrario, es decir, transfiriéndose conscientemente la custodia de la cosa, se desplaza el título de incriminación desde el hurto a la estafa, en su variante concreta de estafa-de-cosa. La anulabilidad del acto de disposición patrimonial (en este caso, por sufrir el vicio de dolo: art. 1548 Código Civil) no obsta a que desde el punto de vista del sistema de los delitos de apropiación se entienda que en este caso de engaño la apropiación de cosa mueble ajena ha sido realizada con el consentimiento del dueño, y que por lo tanto se encuentra excluida del delito de hurto ${ }^{82}$.

Así pues, mientras que la contribución consciente del propietario, poseedor o tenedor coaccionado se mantiene dentro del sistema de los delitos de apropiación ( $\$ \mathbb{S} 1$ a 5

\footnotetext{
80 Esta es una formulación tomada de la doctrina alemana (vid. por todos, Gössel, op. cit. [nota 5], \6 núms. 52 y ss.). En la terminología de la doctrina nacional, podría resumirse lo dicho afirmando que la apropiación es apoderamiento o sustracción con ánimo de tener la cosa como señor y dueño (Enrique Schepeler Vásquez, El delito de hurto, Santiago, 1939, p. 10 y ss.; Alfredo Etcheberry, Derecho Penal, Tomo III, $3^{\text {a }}$ ed. [1998], p. 295296). El contenido del ánimo de apropiación, y en particular su relación con el ánimo de lucro, no serán objeto de análisis en estas páginas.

${ }^{81}$ En el sistema de la Parte Especial del Código Penal chileno, esta extensión del delito de robo no se produce en desmedro del delito de extorsión (art. 438) -que sólo existe en la forma extremadamente fragmentaria de la extorsión documental, heredada de la codificación francesa (vid. nota 55)-, sino en desmedro del delito de amenazas condicionales (arts. $296 \mathrm{~N}^{\circ} 1$ y 2, 297 C.P.).

82 Así, Maurach, Deutsches Strafrecht-Besonderer Teil, $5^{\mathrm{a}}$ ed. (1969), \26-III-B-1, p. 205-206; Samson, en: Rudolphi y otros, op. cit. [nota 5], $27^{\mathrm{a}}$ remisión (1990), \242, núms. 42 y ss.
} 
del Título IX, del Libro II, con el añadido del $\int 5$ bis), la contribución consciente del propietario, poseedor o tenedor engañado es excluida del mismo, pasando al sistema de los delitos de defraudación o delitos contra el patrimonio ( $\$ 7$ del Título IX del Libro II), con todas las consecuencias que quepa deducir de ello según la postura dogmática a que se adhiera en este ámbito de la Parte Especial ${ }^{83}$.

El reconocimiento de esta peculiaridad del robo pone al intérprete en la necesidad de optar por una de las dos posturas interpretativas que ella origina: o bien se reconoce la autonomía de la hipótesis de "compeler a entregar", y se acepta que cualquier acto de disposición patrimonial que se traduzca en el desplazamiento de la custodia sobre una cosa puede ser una entrega para efectos del robo, o bien se la concibe como una hipótesis subordinada a la noción primaria de la apropiación, y se le asigna un alcance mucho más reducido. Todos los antecedentes disponibles apoyan la segunda interpretación ${ }^{84}$.

No puede desconocerse, sin embargo, que aún bajo la interpretación restrictiva subsiste una considerable área de incertidumbre, representada por la zona que se encuentra entre el mero tolerar una acción ajena, en un extremo, y la realización de un acto de disposición patrimonial, en el otro extremo. El manejo de esta zona de incertidumbre deberá lograrse, en primer lugar, mediante un adecuado análisis de los medios comisivos del robo, en particular, otorgando a la intimidación una fisonomía definida como coacción mediante amenaza grave (infra, 4.2-a). Dentro ahora del ámbito de la coacción grave, la forma más segura de establecer una línea demarcatoria que concrete el principio de la vinculación de la entrega a la acción de apropiación es aplicando el criterio de la sustituibilidad de la contribución del coaccionado ${ }^{85}$. En tanto su contribución a la pérdida de su custodia sobre la cosa pueda ser reemplazable en el caso concreto por una ruptura de la misma efectuada de propia mano por el autor del delito, la coacción a hacer la entrega de la cosa es equivalente a la coacción a tolerar su apropiación. En cambio, en los casos en que la contribución del coaccionado sea insustituible, tendrá que reconocerse en ella un acto de disposición patrimonial, excluido del ámbito del robo.

En conclusión, la apertura del robo chileno hacia la extorsión-de-cosa sólo puede explicarse en base al peso específico de la coacción como elemento constitutivo de lo

${ }^{83} \mathrm{La}$ distinción que hace la doctrina alemana dominante entre la propiedad y el patrimonio como bienes jurídicos ha sido recepcionada en la doctrina española principalmente por José Miguel Zugaldía Espinar (op. cit. [nota 6], p. 11 y ss.), y, entre nosotros, por Miguel Soto Piñeiro (La apropiación indebida, Santiago, 1994, especialmente p. 41-43). Una de las cuestiones más importantes involucradas en esta distinción es la de si el objeto de la acción requiere o no ser portador de un valor de cambio (valor pecuniario), cuestión que recibe una respuesta afirmativa tratándose de los delitos contra el patrimonio, pero una negativa tratándose de los delitos contra la propiedad. En este punto, y en términos generales, soy también de la opinión de Miguel Soto, en el sentido que la distinción entre propiedad y patrimonio es una premisa ineludible para la dogmática penal. ${ }^{84}$ Desde un punto de vista sistemático, es obvio que la finalidad del art. 439 es explicitar el alcance una relación normativa que se encuentra configurada en el art. 432, donde la violencia o la intimidación son medios funcionales a la realización de la acción de apropiación. Por otra parte, la regulación de las amenazas condicionales pone explícitamente de manifiesto su carácter de sede relevante para la incriminación de la extorsión (art. $296 \mathrm{~N}^{\circ}$ 1: "exigiendo una cantidad de dinero"). Finalmente, cuando, en el contexto del robo se da un supuesto de exigencia de entrega de dinero (el "rescate" del art. $433 \mathrm{~N}^{\circ}$ 2), el texto legal no lo denomina ni lo considera como un segundo robo, sino que lo tipifica como un injusto adicional y distinto del robo que sirve de base en la configuración del tipo calificado. Más que transformar al robo en una extorsión-de-cosa, con toda la amplitud que esta figura pudiera alcanzar, la finalidad de la regla pareciera encontrarse en evitar objeciones puntuales a la calificación de robo, de la clase que en su tiempo fueran rechazadas por Carpzov.

85 Este criterio es defendido por un importante sector de la doctrina alemana para la demarcación entre el robo y la extorsión; vid., por todos, Günther, op. cit., nota 5, núm. 27. 
injusto. Pues este es el común denominador de una y otra estructura de injusto. En la consideración de la coacción se encuentra, además, una premisa fundamental para la delimitación entre el robo y las amenazas condicionales: los casos de coacción mediante amenazas menos graves que las constitutivas de intimidación no realizan el tipo del robo y deben ser reconducidos a las amenazas condicionales. Finalmente, la historia del desarrollo del elemento coercitivo del robo brinda el criterio final de demarcación: sólo la entrega reemplazable por la apropiación de propia mano es objeto idóneo de coacción en el ámbito del robo.

\subsection{La relación cronológica entre el ejercicio de violencia o intimidación y la apropiación}

Una de las características más peculiares del Código Penal chileno es la de homologar al supuesto de robo en sentido propio -es decir, a la apropiación cometida usando de coacción violenta o intimidatoria en alguna de las relaciones funcionales expresadas en el art. 439- otros supuestos: la comisión de coacción violenta o intimidatoria con anterioridad a la apropiación, para facilitar su ejecución, y su comisión con posterioridad a apropiación, para favorecer la impunidad ${ }^{86}$.

Tratándose de la violencia o intimidación ejercidas con posterioridad a la comisión de la apropiación, es manifiesto que no puede hablarse de robo en el sentido propio del término, tal como es definido en el art. 432 C.P. Ello, por la sencilla razón que si ya se encuentra consumada la apropiación, ésta no se ha cometido "usando" de medios coercitivos violentos o intimidatorios. Tal como lo demuestra el examen del derecho comparado, se trata aquí de una regla que por razones prácticas somete un caso de hurto y coacción (o lesiones u homicidio) al mismo tratamiento penal del robo ${ }^{87}$. Por esta razón, debe evitarse el error en que usualmente incurre la doctrina al definir el concepto de robo incluyendo esta regla como criterio de configuración del tipo ${ }^{88}$. Desde un punto de vista dogmático se trata de un tipo de delito distinto, sometido a un mismo régimen de penalidad y punibilidad ${ }^{89}$.

\footnotetext{
${ }^{86}$ Si bien el texto legal usa la expresión "antes del robo...o después de cometerlo", la doctrina ha advertido que la mención al "robo" en el inciso primero del art. 433 C.P. debe entenderse referida a la apropiación de la cosa mueble ajena en el sentido de lo injusto del hurto. Esta es una tesis correcta. La redacción del precepto legal se explica en parte como un remanente del uso lingüístico vulgar del término "robo", incrustado en la cultura jurídica española de los Siglos XVII, XVIII y primera parte del XIX, como puede apreciarse incluso en la traducción que Pacheco hacía del art. 408 C.P. napolitano (supra, nota 71). En parte se explica también como una transcripción descuidada del art. 38 de la Ley de 7 de Agosto de 1849. En el contexto de esta ley, con los términos "hurto" y "robo" se hacía mención a las acciones de apropiación que eran parte de lo injusto del hurto agravado por la fuerza en las cosas (art. $1^{\circ}$ : "el que sustrae o toma fraudulentamente cosa mueble ajena") y del robo (art. 11: "el que quita alguna cosa mueble ajena”)..

$87 \mathrm{La}$ regla se encuentra, eso sí, defectuosamente configurada, en la medida en que pone el acento exclusivamente en la finalidad de asegurar la impunidad, en circunstancias que la finalidad principal de la norma debería ser la sanción de la coacción ex post dirigida a consolidar la apropiación.

88 Así, Raimundo del Río, Derecho Penal, Tomo III, Santiago, 1935, p. 432-433; Jaime Vivanco, El delito...cit., p. 23; Alfredo Etcheberry, op. cit., p. 336.

${ }^{89}$ Esto lleva a preguntarse si la regla del art. 433 es aplicable también al tipo básico de robo, como lo ha sostenido tradicionalmente la doctrina chilena (loc. cit, nota anterior), o, si debe restringirse sus efectos sólo a los supuestos de robo calificado, como lo ha sugerido Jorge Mera (Comentario a sentencias de las Cortes de Apelaciones de Santiago y San Miguel sobre robo con violencia o intimidación, en: Revista de Ciencias Penales, cit. [nota 1], p. 121-122). Las razones sistemáticas hablan a favor de la primera postura: sería sumamente extraño que el sistema sancionara como robo calificado el hurto seguido de lesiones graves u homicidio, pero no sancionara como robo simple el hurto seguido de coacción violenta o intimidatoria.
} 
Tratándose del caso de la violencia o intimidación ejercidas con anterioridad a la apropiación la situación es distinta, porque al encontrarse aún pendiente la ejecución de la apropiación no se excluye una relación funcional entre ésta y el ejercicio de violencia o intimidación. Dejando de lado el caso de homicidio o lesiones gravísimas calificadas, que es plausible en virtud de la falta de rigurosidad del legislador, desde un punto de vista dogmático la única interpretación aceptable es apreciar en esta parte de la norma del art. 433 inciso primero una declaración expresa de la equivalencia de la coacción y la apropiación como acciones típicamente relevantes para la constatación del principio de ejecución del delito de robo ${ }^{90}$. No se trata, en consecuencia, de una norma que configura un tipo distinto al del robo en sentido estricto, sino de una regla referida al iter críminis de este mismo delito, conforme a la cual el ejercicio de la coacción para facilitar la apropiación constituye ya tentativa de robo.

Nuevamente, es el peso específico de la coacción en la estructura de injusto del robo lo que permite fundamentar la existencia de esta hipótesis e incorporarla en el contexto del robo sin producir incongruencias. Asimismo, en la consideración de la coacción es donde se encuentra el criterio normativo para resolver la principal dificultad que esta hipótesis plantea, que es de índole cronológica, a saber, cuánto tiempo puede admitirse que transcurra entre el ejercicio de coacción y la comisión de la apropiación. A la luz del robo como coacción, la respuesta obvia es que la perduración de la coacción como delito permanente cubre cualquier lapso, y que lo mismo hace la perduración del resultado coercitivo.

\subsection{La relación funcional entre el ejercicio de violencia o intimidación y la apropiación.}

La doctrina considera como una de sus tesis más importantes la exigencia de un nexo subjetivo o ideológico entre el ejercicio de violencia o intimidación y la apropiación, en el sentido que aquél debe encontrarse "al servicio" de ésta en cualquiera de las relaciones estipuladas por el art. 433 (facilitar la ejecución, favorecer la impunidad) o por el art. 439 (forzar a la manifestación, entrega u omisión de oposición o resistencia) ${ }^{91}$.

Como se verá inmediatamente después (infra, 3.4), la exigencia de esta relación final cumple una importante función restrictiva en el ámbito del robo con homicidio, permitiendo su delimitación en relación con el caso frecuente de la comisión de homicidio y hurto posterior. Encontrándose este caso sometido al régimen general de concursos (real), y recibiendo por ello una pena considerablemente menor, se entiende la importancia asignada por la doctrina al requisito del nexo subjetivo. Es precisamente en este contexto que la jurisprudencia ha mantenido esta misma tesis ${ }^{92}$. Sin embargo, como también se verá en ese mismo lugar, la necesidad de distinguir entre robo con homicidio y homicidio con hurto en base a consideraciones subjetivas obedece principalmente a la falta de rigor con

\footnotetext{
${ }^{90}$ Esta es la interpretación de Alfredo Etcheberry (op. cit., loc. cit.).

${ }^{91}$ Jaime Vivanco, La figura...cit. infra, nota 96, p. 36-37; del mismo: El delito...cit. infra, nota 96, p. 20-22; Carlos Künsemüller, Comentario...(1978) cit. infra, nota 96, p. 49; del mismo: Comentario...(1978-1981) cit. infra, nota 96, p. 168; Jorge Mera, Comentario...cit.supra, nota 89, p. 121; Alfredo Etcheberry, op. cit., p. 336-337.

92 Así, por ejemplo, Contra Angel Arancibia Olmedo, Corte Suprema, 4 de Diciembre de 1953, en: Revista de Derecho y Jurisprudencia, Tomo L (1953), $2^{\mathrm{a}}$ parte, sección $4^{\mathrm{a}}$, p. 254 y ss.; Contra Eleuterio Provoste y otro, Corte Suprema, 17 de Enero de 1979, en: Revista de Ciencias Penales, Tomo XXXVII-2 (1978-1981), p. 155 y ss. Para un examen de la jurisprudencia sobre este punto, Edwards Orrego y Melo Iglesias, op. cit. [nota 84], p. 12; Carrasco Ferrari, op. cit. [nota 84], p. 38 y ss.
} 
que la ley y la doctrina configuran el concepto de robo con homicidio, admitiendo en él casos que difícilmente podrían ser considerados como una apropiación coercitiva.

Partiendo de la concepción del robo como coacción es evidente que la relación existente entre violencia o intimidación y apropiación no es subjetiva sino funcional. La violencia y la intimidación son los medios coercitivos con cuyo ejercicio se produce alguno de los resultados de coacción que hacen posible o facilitan la apropiación. Vistas así las cosas, es evidente que la insistencia doctrinaria en la constatación de un puro nexo subjetivo -además del cronológico- constituye una disminución de los requisitos que deben ser satisfechos para la realización del tipo de robo.

A la luz del tenor literal del Código Penal, es cierto que este es el único requisito funcional exigido por el principio de legalidad como presupuesto de punibilidad del robo $^{93}$. No obstante, cuando se asume que el robo es coacción, surge inmediatamente como cuestión crucial si es necesario constatar una relación causal objetiva, en el sentido que la coacción efectivamente haya posibilitado la apropiación, o si basta con que el autor haya ejercido la coacción para posibilitar la apropiación ${ }^{94}$. Y la respuesta correcta debe ser la primera: la mera exigencia de un nexo subjetivo, radicalmente asumida, equivaldría a admitir incluso la punición de la tentativa inidónea de coacción como delito consumado de robo, si hubiera apropiación.

\subsection{Las relaciones entre el tipo básico y los tipos calificados de robo ${ }^{95}$}

Sin lugar a dudas, la hipótesis típica de robo que más atención ha recibido de la doctrina chilena es la de robo con homicidio ${ }^{96}$. Este fenómeno encuentra una obvia explicación en la importancia práctica del supuesto en cuestión, debida a la magnitud de las consecuencias asociadas por la ley a su realización. Ello ha llevado, sin embargo, a que

${ }^{93} \mathrm{El}$ art. 342 exige que la apropiación se cometa "usando" violencia o intimidación. El art. 433 exige que el uso de violencia o intimidación previo a la apropiación y el uso posterior tengan lugar "para" el logro de ciertos fines. Por su parte, el art. 439 igualmente exige sólo el uso "para" la obtención de ciertos resultados. La exigencia cronológica es la única de carácter objetivo. Así pues, desde el punto de vista del principio de legalidad, las exigencias funcionales pueden entenderse satisfechas en el puro plano subjetivo.

94 Esta es una cuestión sumamente discutida en la doctrina alemana. La doctrina dominante se inclina por diversas razones por estimar suficiente una conexión puramente subjetiva entre el ejercicio del medio coercitivo y la apropiación (vid., por todos, Herdegen, op. cit. [nota 5], \249, núms. 13-15). En contra de la tesis dominante, Günther ha sostenido que si el robo supone la coacción, entonces es ineludible la exigencia de una conexión causal objetiva entre el medio coercitivo y la apropiación (op cit, [nota 5], \249, núms. 35-36). Conforme con esta última tesis, Kindhäuser, op. cit., nota 5, \13, núm. 17-21.

${ }^{95}$ Los supuestos de robo calificado que requieren análisis son los de robo con homicidio y robo con lesiones. El robo con secuestro (art. $433 \mathrm{~N}^{\circ}$ 2) es un caso obvio de agravación de la coacción propia del robo simple, por su transformación en una privación de libertad grave, en virtud de la intensidad de la lesión de la libertad de abandono del secuestrado (más de un día), o de su función coercitiva ulterior (rescate). El robo con violación es un caso obvio de concurso real sustraído al régimen general del art. 74.

${ }^{96}$ José Victorino Lastarria, Verdadera inteligencia de la Ley de 3 de Agosto de 1876, en: Revista Forense de Chile, Tomo II (1886), p. 84 y ss.; Federico Peña, El robo con homicidio, en: Revista de Ciencias Penales, Tomo I (1936), p. 21 y ss.; Lionel Edwards Orrego, Efraín Melo Iglesias, Jurisprudencia del delito de robo con homicidio, Santiago, 1947; Eduardo Quezada Roldán, op. cit. [nota 71]; Ignacio Echeverría Maroto, Naturaleza jurídica del delito de robo con homicidio, en: Revista Gaceta Jurídica, Tomo XLVIII (1951), $1^{\text {a }}$ parte, p. 25 y ss.; Jaime Vivanco, La figura delictiva del robo con homicidio, en: Revista de Ciencias Penales, Tomo XV-2 (1956), p. 33 y ss.; del mismo, El delito de robo con homicidio, Santiago, 1957; María A. Carrasco Ferrari, Jurisprudencia sobre el delito de robo con homicidio, Santiago, 1966; Carlos Künsemüller Loebenfelder, Comentario a sentencia, en: Revista Gaceta Jurídica, No 26 (1978), p. 45 y ss.; del mismo: Comentario a sentencia, en: Revista de Ciencias Penales, XXXVII $(1978-1981) \mathrm{N}^{\circ} 2$, p. 163 y ss. 
muchas de las cuestiones más importantes del delito de robo hayan sido planteadas desde una perspectiva dogmáticamente incorrecta. Pues entre el ejercicio de coacción y la comisión de homicidio como medio de apropiación existen diferencias manifiestas.

Uno de los principios sistemáticos de la protección penal de la libertad consiste en que el resultado de privación o restricción de la libertad de acción perseguido por el autor del ataque sea comparativamente tanto o más relevante que la afectación de su capacidad de acción causada por el medio o modo de ataque concretamente utilizado para constreñirlo. Si, en cambio, el medio o modo de ataque es considerablemente más grave, entonces prevalece como único título de incriminación. En virtud del principio del ne bis in idem, debe estimarse que el delito de coacción mediante violencia sólo es compatible como título de incriminación con lesiones que producen una incapacidad general de acción de hasta cierta gravedad, lo cual originará un concurso aparente resuelto en favor de la coacción o bien un concurso ideal. Sobrepasándose esa gravedad, la sola incriminación a título de lesiones u homicidio expresa ya el disvalor de injusto de la lesión a la libertad, porque la afectación de la capacidad de acción que acarrea la muerte o la lesión gravísima es el fundamento material de su incriminación.

Pero esta no es sólo una cuestión formal de relaciones entre normas, sino que concierne a la constatación material de la libertad personal como bien jurídico protegido. La vida y la incolumidad personal son bienes jurídicos merecedores de protección penal porque constituyen presupuestos indispensables para el libre desarrollo de la personalidad. Por lo mismo, cuando a raíz de la afectación de esos bienes se produce también una afectación total o exorbitante de la capacidad general de acción de la persona (muerte, invalidez), se encuentra lisa y llanamente fuera de lugar la identificación de algún ámbito concreto y específico de acción como objeto relevante de ataque. La muerte es la más grave vulneración imaginable al libre desarrollo de la personalidad, pero precisamente por eso es que no se puede decir con sentido que la muerte impida realizar tal o cual acción. Lo mismo cabe decir de lesiones graves: el que mutila a un pianista rival para que no participe en una competencia no lo constriñe a omitir tomar parte en ese concurso sino que destruye su condición de pianista. Sólo un ser capaz de acción puede ser objeto de coacción.

Teniendo presente lo anterior, es forzoso reconocer que las relaciones entre la comisión de homicidio y lesiones, por una parte, y la realización de la acción de apropiación de la cosa mueble ajena, por la otra parte, pueden ser muy distintas, dependiendo de la presencia o ausencia de una acción de coacción dirigida a hacer posible la apropiación.

El caso más simple y obvio es aquel en el cual se realiza el tipo básico de robo, es decir, se constriñe mediante violencia o intimidación a tolerar la apropiación, a hacer entrega de la cosa o a manifestarla, ocasionándose además un resultado de muerte o lesiones que es objetiva y subjetivamente imputable al uso de los medios coercitivos, como concreción de un peligro creado por el ejercicio de violencia o intimidación ${ }^{97}$. En

\footnotetext{
${ }^{97}$ Esto implica que los resultados de muerte o lesiones objetiva y subjetivamente imputables a la acción de apropiación de la cosa mueble ajena, por oposición a la acción de coacción, no realizan el robo calificado. Y la razón sistemática es obvia: si la calificación pudiera satisfacerse con resultados de la acción de apropiación, no habría motivo para restringirla al robo. El hecho que sólo el robo (y no el hurto ni el robo con fuerza en las cosas) reciba estas calificaciones demuestra que son resultados de aquél elemento constitutivo de lo injusto del
} 
este caso, se trata de una calificación cuya finalidad es reemplazar la regla general del concurso ideal (propio) entre el delito de robo simple y los delitos dolosos (paradigmátricamente, con dolo eventual) o imprudentes respectivos.

Distinto es el caso en el que se realiza el tipo básico de robo, y durante su comisión se comete además homicidio o lesiones, sin que éstas puedan considerarse como un resultado del uso de los medios coercitivos, sino que son el resultado de otra acción, distinta de la coacción propia del robo. Desde un punto de vista sistemático, no existe aquí el fundamento de incriminación del caso anterior, ya que el resultado de muerte o lesiones no fundamenta la apreciación de una mayor gravedad de la acción típica del robo. Aquí la calificación tiene por finalidad reemplazar la regla general del concurso real entre el robo simple y el delito adicional cometido.

Finalmente, el homicidio o las lesiones pueden constituir el medio del cual se vale el autor del delito para excluir deliberadamente los posibles obstáculos a la acción de apropiación. En este caso, no hay una acción de coacción previa al resultado mortal o lesivo, sino que esa muerte o lesión sustituye funcionalmente el empleo de medios coercitivos. Este es un caso, la calificación tiene por objetivo reemplazar la regla general de concurso ideal (impropio) entre el delito doloso (con dolo directo, e incluso premeditación) de homicidio o lesiones, que es el delito-medio, y el delito de apropiación (distinto del robo simple), que es el delito-fin.

La doctrina expresa sin vacilación su preferencia por el tercer caso como correlato paradigmático del robo calificado, bastándole la existencia de inmediatez cronológica y de un nexo subjetivo entre la comisión de homicidio o lesiones y la comisión de la apropiación, consistente en que el homicidio o las lesiones sean cometidos para apropiarse de cosa mueble ajena ${ }^{98}$. Esto se expresa legalmente en la consideración del robo con homicidio y del robo con lesiones como casos en que el homicidio o las lesiones son adicionalmente cometidos "con motivo" de la comisión del robo.

La razón de fondo de esta preferencia de la doctrina se encuentra en su deficiente concepción de la violencia como un comportamiento desligado de la coacción. Este déficit no resulta sorprendente, si se tiene presente que la monografía que hasta el día de hoy constituye la última palabra entre nosotros en materia del delito de robo con homicidio, restringe estipulativamente su análisis al homicidio cometido mediante maltrato de obra ${ }^{99}$, para luego afirmar que todo robo con homicidio es genéricamente considerado un robo con violencia ${ }^{100}$. Pero si el robo simple es un delito de coacción, como lo impone el art. 439, entonces la concepción de la doctrina es incorrecta.

La construcción dogmática correcta de este caso de robo calificado ("con motivo") exige asumir que el homicidio y las lesiones no constituyen la culminación o grado máximo de la violencia del robo simple, sino que, por el contrario, la reemplazan. No se trata de casos en que la violencia coercitiva del robo simple se concreta en un resultado de muerte o lesiones, porque en estos casos no existe violencia coercitiva. Lo

robo que es propio y privativo de este delito, o sea, la coacción.

98 Particularmente claro en este punto, Carlos Künsemüller, Comentario...(1978), cit. [nota 96], p. 48.

${ }^{99}$ Jaime Vivanco, El delito...cit., p. 31.

100 Ibidem, p. 41. 
que sucede aquí es que la muerte o las lesiones representan un modo de ataque funcional a la ruptura de la custodia sobre la cosa que es alternativo a la coacción violenta.

Esta construcción dogmática permite enfrentar en mejor pie la gran dificultad que la regulación chilena plantea en este caso de robo calificado. Conforme al texto legal, el robo con homicidio o lesiones parece presuponer siempre ejercicio de violencia o intimidación, incluso en el supuesto de la comisión de homicidio o lesiones "con motivo" de la comisión del robo. La doctrina intenta sortear esta dificultad argumentando que el "robo" a que se refiere el art. 433 no es más que la apropiación de la cosa, y que por lo tanto no se requiere una apropiación con coacción violenta o intimidatoria y además la comisión de homicidio o las lesiones, sino que en la comisión de homicidio o lesiones se concreta el ejercicio de violencia que constituye el robo ${ }^{101}$. Esta interpretación del sentido de la expresión "robo" en el art. 433 es correcta, al menos en lo que respecta al contexto del encabezamiento del artículo, tal como se ha dicho antes ${ }^{102}$. Pero eso no quita que la muerte o la lesión deban ser el resultado de una acción violenta o intimidatoria.

Cuando la doctrina proclama que el homicidio y las lesiones son una sub-clase de violencia, y que por lo tanto el problema se resuelve constatando en ellos la violencia requerida por el tipo ${ }^{103}$, o bien incurre en una tautología o bien formula una interpretación extensiva inadmisible. Si la muerte y las lesiones son el resultado de una acción violenta, entonces es tautológicamente obvio que constituyen subclases de violencia. Pero eso deja fuera del delito de robo calificado todos los casos de comisión de homicidio o lesiones por medios no violentos (como por ejemplo, la comisión por omisión, el ocasionamiento de la autolesión mediante engaño, el envenenamiento), sin que esta exclusión tenga fundamento alguno desde el punto de vista del disvalor material de injusto conforme a esta misma concepción ${ }^{104}$. Si, por el contrario, se quiere afirmar que toda muerte y toda lesión son calificables de "violencia", independientemente de la forma concreta de su comisión, entonces se extiende de modo inadmisible el sentido de la expresión en cuestión, pues desde todo punto de vista la violencia designa un modo especial de acción o ataque y no un resultado lesivo.

En cambio, cuando se reconoce que la muerte o las lesiones del custodio o de su potencial defensor son en este caso un medio de ataque necesariamente alternativo a la violencia coercitiva, entonces no puede sino concluirse que la tipificación del homicidio o las lesiones "con motivo" de la apropiación, como supuesto de robo calificado, implica una redefinición de la estructura de injusto tal que ya no es exigible, en estos casos, el carácter violento del ataque, ni mucho menos su carácter intimidatorio.

En lo que respecta al caso de la comisión de homicidio o lesiones simultáneamente con la comisión de robo, esto es, el segundo caso arriba mencionado, la doctrina rechaza por lo general su incriminación bajo el título de robo calificado ${ }^{105}$. La

\footnotetext{
101 Por todos, Jaime Vivanco, El delito...cit., p. 23-24 y 41 y ss.

102 Supra, nota 86.

103 Jaime Vivanco, La figura...cit., p. 46-47; del mismo: El delito...cit., p. 39; Carlos Künsemüller, Comentario...(1978) cit., p. 47.

104 Así, Bajo Fernández, Pérez Manzano, op. cit. [nota 3], p. 124-125, y los autores ahí citados. Esta distinción tajante entre homicidio violento, incluido en el robo con homicidio, y homicidio no violento, excluido de él, sólo resulta dogmáticamente plausible si se asigna al carácter violento de la acción un sentido político-criminal distinto de la mera creación de un peligro para la vida.

105 Así, Eduardo Quezada, op cit., p. 35; Jaime Vivanco, El delito..cit., p. 64 y ss; Carlos Künsemüller,
} 
diferencia con los otros dos casos es tan evidente desde un punto de vista sistemático que no cabrían dudas acerca de la corrección de darle un tratamiento diferenciado, como un caso de homicidio o lesiones que las más de las veces será calificado por la alevosía, en concurso real con el robo. Sin embargo, lo que resulta precisamente dudoso es que la legislación chilena asuma el planteamiento sistemático correcto.

El Código Penal chileno es un texto legal que incrimina a título de robo calificado la comisión de homicidio o lesiones al igual que de violación, cuando ello tiene lugar "con ocasión" del robo. Es evidente que la comisión adicional del delito de violación sólo puede encontrarse en una relación de concomitancia con la coacción del robo, sin que sea pertinente plantearse su consideración como un resultado grave de la violencia coercitiva constitutiva de robo ni como medio alternativo de ataque funcional a la apropiación. Por esta razón, resulta más que discutible que desde el punto de vista del texto legal el homicidio o las lesiones cometidas en este mismo sentido "con ocasión" del robo deban entenderse como excluidas del tipo de robo calificado ${ }^{106}$.

Finalmente el primer caso arriba mencionado es el caso paradigmático de robo calificado para la concepción del robo como coacción. Pues en este caso, y sólo en este caso, se concreta en un resultado lesivo para la vida o la incolumidad personal un peligro eventualmente creado por el uso de violencia o intimidación como medios de coacción. Este es el caso clásico de calificación por la producción de un resultado ulterior más grave, objetiva y subjetivamente imputable. La procedencia de este caso como supuesto de robo calificado es, por cierto, rechazada por la doctrina, en virtud de su preferencia por una concepción del robo calificado subordinada a la fórmula "con motivo". Pero el caso es enteramente admisible a la luz del texto legal, pues representa la otra posibilidad

Comentario....(1978), cit., p. 49; Gustavo Labatut Glena, op. cit. [nota 13], p. 202-203; Alfredo Etcheberry, op. cit., p. 341-342. La justificación de esta tesis se encuentra en una interpretación de la expresión legal "con ocasión" como mención al acaecimiento de un resultado de muerte o lesiones objetiva y subjetivamente imputable a la violencia o intimidación coercitivas, o sea, en el sentido del caso anteriormente tratado como supuesto paradigmático de robo calificado.

106 Citando en su favor la opinión del Profesor Alvaro Bunster, Jaime Vivanco explica el robo con violación como el producto de una idea regulativa específica y distinta de la del robo con homicidio o lesiones, cual es la correspondiente a la noción de "salteo" (La figura...cit., p. 47; del mismo: El delito...cit., p. 37-38). El concepto de salteo, heredado del derecho español, no es preciso; esta idea se relaciona con el hecho de cometerse el delito de robo con violencia o intimidación en cuadrilla, y primariamente en caminos públicos o sitios despoblados; de aquí que lo característico del salteo pareciera ser la creación de una situación de poder sobre las personas; en consecuencia, la razón de la configuración de un supuesto de salteo, sancionado con las penas más severas del robo, pareciera encontrarse en el aprovechamiento de la vulnerabilidad e indefensión de la víctima (al respecto, vid. Jorge Cortés, op. cit. [nota 59], p. 1 y ss.). A pesar de lo incierto de sus contornos, la idea regulativa del salteo ejerció una profunda influencia en las representaciones del legislador chileno en la segunda mitad del Siglo XIX, tanto en la Comisión Redactora del Código Penal (vid. Sesión 80, en 6 de Mayo de 1872, en: Actas...cit., p. 401-402) como en el Congreso Nacional inmediatamente posterior (Echeverría, op. cit., p. 28 y ss.). Esto no significa, sin embargo, que el robo con violación obedezca en el contexto del Código Penal a una idea regulativa distinta a la del robo con homicidio. Lo único que no puede deducirse de la evolución experimentada por la regulación del robo calificado entre el texto originario del Código y el texto fijado por la Ley 13.303 es una voluntad legislativa de tratamiento diferenciado del robo con homicidio y el robo con violación. En efecto, habiendo sido tratados originalmente en dos numerandos diversos con fórmulas gramaticales distintas, la comisión de violación y la comisión de homicidio pasaron a ser tratadas en un mismo numerando con una misma fórmula gramatical. Conforme a todos estos antecedentes no habría razón para restringir el alcance del sentido de la expresión "con ocasión" como mención a una acción adicional sólo a la comisión de violación. Con igual fundamento cabría interpretar al robo calificado del art. $433 \mathrm{~N}^{\circ} 1$ como un supuesto comprensivo también de la comisión de robo con violencia o intimidación con ocasión del cual se comete además homicidio o lesiones gravísimas. 
interpretativa de la fórmula "con ocasión". La producción del resultado lesivo como concreción del peligro creado por la comisión de la coacción es comisión de ese resultado "con ocasión" de la comisión del robo.

Lo más discutido respecto de este caso es su ámbito de extensión en relación con la imputación sujetiva del resultado letal o lesivo. Es decir, si sólo se restringe a la imputación a dolo o si se extiende además a la imputación a imprudencia. La doctrina opta por la primera alternativa, sosteniendo que la expresión "cometiere además" exige comisión dolosa ${ }^{107}$. El argumento no es concluyente. La expresión "cometiere además" fue introducida por la Ley 13.303, sustituyendo la expresión previa "resultare además". La razón de esta modificación fue impedir la consideración del robo como un delito calificado por el resultado, en el sentido del versari in re illicita. Luego, en la medida que la imprudencia sea una forma de imputación compatible con el principio de culpabilidad, no hay objeción sistemática que oponer a su inclusión dentro del ámbito típico del robo calificado ${ }^{108}$.

Desde un punto de vista sistemático es mucho más correcta la interpretación amplia del concepto de "cometer", comprensivo no sólo de la comisión dolosa, sino de la comisión imprudente. El modelo de la calificación por la concreción del peligro que puede portar la coacción violenta o intimidatoria es el modelo regulativo histórica, comparatista y político-criminalmente más importante. Además, si se parte de la base que la comisión imprudente de homicidio o lesiones graves requeriría en todo caso expresión en la determinación de la pena conforme al régimen de concursos ${ }^{109}$, entonces es incluso más congruente con el principio de proporcionalidad incluir el supuesto de comisión imprudente en el robo calificado que dejarlo entregado a las reglas generales de concurso con el robo simple ${ }^{110}$. Las consideraciones de proporcionalidad que sirven de fundamento a la postura contraria encuentran, pues, un contexto más favorable en el art. 433 que en el régimen de concursos ${ }^{111}$.

En todo caso, no está de más observar que la comisión de homicidio o lesiones con dolo eventual en rigor corresponde a este caso de robo calificado, y no al supuesto que se expresa en la fórmula "con motivo". Pues el dolo eventual requiere la realización de una acción que no se encuentra intencionalmente dirigida a la producción del resultado,

107 Por todos, Etcheberry, op. cit., p. 338-340.

$108 \mathrm{El}$ argumento contrario, basado en los arts. $2^{\circ}$ y $10 \mathrm{~N}^{\circ} 13$ C.P., conforme al cual sin declaración expresa de la ley no hay responsabilidad penal por imprudencia, desconoce que el art. 433 C.P. no es constitutivo del injusto típico de la circunstancia calificante -sí lo es, por supuesto, de su calidad de calificación típica del robo, sino que se remite a los tipos de injusto ya constituidos por otras normas de la Parte Especial. Por su parte, el argumento que deduce de la razón de la Ley 13.303 la necesidad de tratar diferenciadamente la comisión dolosa y la comisión imprudente es un argumento analógico o sistemático, pero no un argumento genético (teleológico-histórico). Es cierto que la proporcionalidad es una consecuencia del principio de culpabilidad, tal como lo es la exigencia de imputación subjetiva. Con todo, son dos consecuencias distintas, y la perseguida por el legislador histórico fue sólo esta última.

109 Así, Etcheberry, op. cit., p. 339-340.

${ }^{110}$ En este último caso, la pena sería por regla general la de presidio menor en su grado máximo (art. 75, en relación con los arts. 436 inciso primero y 492 en concordancia con el art. $391 \mathrm{~N}^{\circ}$ 2). Bajo el art. 433, en cambio, el marco penal admite la pena de presidio menor en su grado medio.

${ }^{111}$ Lo dicho no significa adherir a la política criminal que inspira la regulación actualmente vigente. Desde el punto de vista de una política criminal racional, el robo simple en ningún caso debería recibir una pena superior a la de presidio mayor en su grado mínimo, y el robo calificado por lesiones o muerte en ningún caso debería recibir una pena superior a la del homicidio calificado (art. $390 \mathrm{~N}^{\circ}$ 1) o las lesiones respectivas agravadas por las circunstancias equivalentes (art. 400). 
y en el contexto del robo esa acción no puede ser sino la coacción violenta o intimidatoria ${ }^{112}$.

En conclusión, de lege lata debe reconocerse que la legislación chilena no ha seguido rigurosamente un punto de vista sistemático definido en la regulación del robo calificado, sino que ha tratado conjuntamente supuestos que requerirían un tratamiento diferenciado ${ }^{113}$. El desconocimiento por la doctrina del presupuesto básico del análisis -la concepción del robo como coacción- ha impedido este reconocimiento.

\subsection{La relación entre el robo y el así denominado "robo por sorpresa"}

El art. 436 inciso segundo del Código Penal sanciona con la pena de presidio menor en sus grados medio a máximo, considerándola como robo, la acción consistente en "la apropiación de dinero u otras especies que los ofendidos lleven consigo, cuando se proceda por sorpresa o aparentando riñas en lugares de concurrencia o haciendo otras maniobras dirigidas a causar agolpamiento o confusión". Este delito, denominado entre nosotros "robo por sorpresa", ha constituido una permanente fuente de dificultades para la legislación, la doctrina y la jurisprudencia ${ }^{114}$.

Aunque entre 1875 y 1954 el robo por sorpresa revistió en el Código Penal chileno el carácter de un supuesto agravado de robo simple, se trata en rigor de una hipótesis de hurto propio que históricamente fue asimilada al robo en el derecho español y chileno, ya sea para efectos de la penalidad o para hacerle extensivas reglas especiales aplicables al robo ${ }^{115}$. Esta última es la caracterización que corresponde a su regulación

112 Así lo ha reconocido recientemente la Iltma.. Corte de Santiago, calificando la muerte imputable a dolo eventual como homicidio cometido "con ocasión" (Contra Marcelo Andrés Valenzuela Aspee y otros, 31 de Enero de 2002, en: Revista Gaceta Jurídica N²59 (2002), p. 136-140).

113 Los antecedentes de la historia fidedigna del precepto así lo demuestran. Tanto la Ley de 7 de Agosto de 1849 (art. 17) como la Comisión Redactora en su primera decisión al respecto (Sesión 80, en 6 de Mayo de 1872, Actas...cit., págs- 401-402) consideraron al robo con homicidio como una clase de homicidio; asimismo, la tipificación del robo con homicidio fue considerada por la Comisión como una traslación de las disposiciones relativas al homicidio calificado (Sesión 91, en 5 de Junio de 1872, Actas...cit., p. 419).

114 Ya en el siglo pasado, José Victorino Latarria, Del robo con violencia e intimidación en las personas, en: Revista Forense Chilena II (1886), p. 129 y ss.

115 Los arts. 731 y 732 del Código Penal español de 1822 sancionaban como robo casos de arrebatamiento por sorpresa de cosas portadas, "aunque sin hacerle fuerza ni violencia" al ofendido. Estas disposiciones no perduraron en la fase madura de la codificación española, pero sí fueron recepcionadas por la Ley chilena de 7 de Agosto de 1849, aunque con una extraña redacción. El art. 20 de la ley antedicha sancionaba a "los que robasen ropas, alhajas u otros efectos, arrebatándoselos por sorpresa a la persona que los lleva consigo, i los que aparentando riñas en lugar de concurrencia, o haciendo otras maniobras dirijidas a causar agolpamiento $\mathrm{i}$ confusión, roben por este medio o proporcionen que roben sus compañeros, sin hacer fuerza o violencia en el sentido del art. 12". La misma disposición establecía como sanción tres a dieciocho meses de prisión, "a mas de la pena del robo". La anomalía de esta redacción radica en que la hipótesis parece presuponer un "robo", en circunstancias que expresamente excluye esa posibilidad al exigir que no haya uso de fuerza o violencia. La explicación se encuentra, naturalmente, en que la expresión "robo" se usa en un sentido vulgar, como sinónimo de "sustracción" o "apoderamiento". La Comisión Redactora del Código Penal se dejo, sin embargo, engañar por el aparente tenor literal del precepto, estableciendo en el inciso segundo del art. 436 C.P. una agravación de las penas del delito de robo simple (inciso primero del art. 436 C.P.), para los casos del art. 20 de la Ley de 7 de Agosto de 1849. Este error perduró no obstante las reformas introducidas por las Leyes 3.988 (1923), 5.507 (1934), 11.183 (1953), así como por el D.L,. No 26, de 1932. Sólo con las modificaciones introducidas por la Ley 11.625 (1954) se produjo la diferenciación entre el robo y el robo por sorpresa, la cual se tradujo casi veinte años más tarde en una diferenciación de penalidades, en virtud de la Ley 17.727 (1972). 
actual en el Código Penal chileno. De aquí que en el derecho penal chileno sea una cuestión práctica relevante determinar cuando procede la calificación de robo (art. 436 inciso primero) y cuando sólo la de "robo por sorpresa" (art. 436 inciso segundo).

En tiempos recientes, la Iltma. Corte de Apelaciones de San Miguel ha desarrollado un intento de delimitación entre ambos supuestos de hecho basado en la falta de relación típicamente significativa entre el ejercicio de la violencia y la apropiación. Esta tesis fue primero esbozada en un voto disidente ${ }^{116}$, que fue respaldado doctrinariamente por Jorge Mera ${ }^{117}$, convirtiéndose más tarde este respaldo en la ratio decidiendi del voto de mayoría de la Corte ${ }^{118}$. El argumento crucial es el siguiente:

“...lo que se desvaloriza en esta figura de excepcional gravedad es la relación especial que se da entre la violencia o la intimidación en las personas (por ejemplo lesiones) y la apropiación. No basta con que objetiva y subjetivamente existan ambos injustos (lo que daría lugar sólo a un concurso entre hurto y lesiones); es preciso que la violencia en las personas (lesiones, en lo que ahora interesa) se realice para obtener la apropiación, lo que obviamente no sucede cuando las lesiones son sólo el efecto inherente de la apropiación rápida y sorpresiva de los objetos que las personas llevan consigo."119

En este fragmento hay un reconocimiento intuitivo de la idea de la coacción, unido sin embargo a su falta de expresión conceptual. La tesis sostiene que el robo no está compuesto de la apropiación más el mero ejercicio de violencia (vías de hecho, lesiones), incluso si hay dolo respecto del resultado lesivo; además de todo eso se requiere un elemento adicional, un plus de injusto, que se define como "una relación especial" entre apropiación y violencia, consistente en que ésta se realice para obtener la apropiación. Como resultará obvio, esta relación especial no es otra cosa que el resultado de coacción que debe obtenerse mediante el ejercicio de la violencia, el cual debe ser funcionalmente idóneo para fundar una relación causal objetiva entre coacción violenta y apropiación.

Sólo la comprensión del robo como coacción hace explicable que un tirón de la cosa que rompe una oreja (en el primer caso) o que incluso arroja al ofendido al suelo (en el segundo) pueda ser calificado como "una apropiación rápida y sorpresiva" en la que "obviamente" no sucede que se "realice" la violencia "para obtener la apropiación". Pues, como se comprenderá, no puede negarse que el tirón implique un despliegue de fuerza física o mecánica; ni tampoco es discutible que el despliegue de fuerza física o mecánica sea calificable de violencia en un sentido jurídico penal. Por último, también es evidente

\footnotetext{
116 Contra Mario Gabriel Baeza Faúnder, sentencia de 19 de Mayo de 1993, en: Revista de Ciencias Penales, Tomo XLIII (1994) No 3, p. 113-115

117 Comentario a sentencias...cit. [nota 1], especialmente p. 121-122.

118 Contra Pedro Amaya Marchant, sentencia de 10 de Enero de 1997, en: Revista Gaceta Jurídica No 199 (1997), p. 143-146. La línea jurisprudencial originada por esta tesis es la siguiente: Contra Marcelo Valdebenito San Martín, sentencia de 10 de Junio de 1998, en: Revista Gaceta Jurídica No 216 (1998), p. 158-160; contra Daniel R. García Abarca, sentencia de 25 de Abril de 2001, en: Revista Gaceta Jurídica No 251 (2001), p. 144-146; contra Juan M. Marín Zúniga, sentencia de 29 de Octubre de 2001, en: Revista Gaceta Jurídica No 256 (2001), p. 188-193.

118 Comentario...cit., pág. 122; transcrito en la sentencia Contra Pedro Amaya Marchant, loc. cit., pág. 145.

119 Comentario...cit., p. 122; transcrito en la sentencia Contra Pedro Amaya Marchant, loc. cit., p. 145.
} 
que la ruptura de la esfera de custodia y constitución de una nueva esfera de custodia se logró en virtud de ese despliegue de fuerza física. En tales circunstancias, la única forma como la teoría de Jorge Mera podría eludir la calificación de robo es atendiendo al peligro concreto que el tirón pueda crear para la vida o la incolumidad personal. Pero como es evidente, una brusca sacudida del cuerpo de una persona desprevenida por lo general será calificable como una acción que crea un riesgo semejante ${ }^{120}$.

Si algún criterio dogmático puede invocarse para defender el intento demarcatorio de la Iltma. Corte de San Miguel, ese se encuentra en la incompatibilidad que existe entre la supresión de la capacidad personal de formación o ejecución de la voluntad (violencia coercitiva) ejercida para vencer una resistencia opuesta o esperada a la ruptura de la esfera de custodia, por una parte, y, por otra parte, la repentina alteración de la esfera misma de custodia. La formulación de los criterios precisos para establecer esta línea demarcatoria no es tarea fácil, y de ahí lo vacilante de la jurisprudencia comparada ${ }^{121}$. En todo caso, el punto de partida de esa tarea es el reconocimiento de la diferencia existente entre la existencia o inexistencia de coacción.

\subsection{La relación entre el robo y la autotutela ilícita}

El art. $494 \mathrm{~N}^{\circ} 20$ del Código Penal chileno configura como una falta, sancionándola con pena de multa, la conducta del que con violencia se apoderare de una cosa perteneciente a su deudor para hacerse pago con ella. Esta disposición agrega a la desproporcionada severidad del tratamiento penal del robo una benignidad no menos desproporcionada para el tratamiento de la autotutela ilícita, aumentando con ello exponencialmente las dificultades para la reconstrucción racional de la protección penal de la propiedad.

Jorge Mera pretende explicar la diferencia entre el robo y la autotutela ilícita en virtud de una mayor o menor gravedad de los medios comisivos empleados. Según él, cuando la violencia trasciende el atentado a la propiedad por la puesta en peligro concreto de la vida o incolumidad personal hay robo, aún cuando se trate de un apoderamiento cometido por el acreedor de cosa mueble perteneciente al deudor para hacerse pago con ella; cuando, por el contrario, la violencia no tiene esa trascendencia, el acreedor realiza la falta de autotutela ilícita. De este modo, la autotutela ilícita resulta ser un tipo privilegiado en relación no con el robo sino que con el hurto ${ }^{122}$.

\footnotetext{
120 Este fue precisamente el caso en contra Marcelo Valdebenito San Martín, cit., nota 118. A consecuencia del arrebatamiento de su billetera, la víctima, una mujer de setenta años de edad, cayó al suelo sufriendo lesiones graves. La Corte negó la calificación como robo simple, aduciendo que las lesiones no habían sido cometidas dolosamente ni con el propósito de obtener la apropiación (cons. 6, 8, 9 y 11, p. 158-159). El argumento es incorrecto: no son las lesiones irrogadas (resultado) sino el maltrato que las causó (acción) lo que cuenta como violencia, siempre que, según la tesis de Mera, esa violencia sea además peligrosa. Y ésta lo fue, manifiestamente. La única razón que podría justificar esta decisión sería reconocer que esa violencia, aunque funcional a la apropiación y objetivamente peligrosa, no fue sin embargo coercitiva.

$121 \mathrm{Al}$ respecto, vid. Bajo Fernández-Pérez Manzano, op. cit., p. 104; Herdegen, op. cit., \249, núm 8. Esta dificultad afecta también algunos de los casos resueltos por la Iltma.. Corte de San Miguel, en los cuales la decisión es justificada en base a consideraciones exclusivamente subjetivas que están fuera de lugar, ya que el tipo del robo simple no exige un resultado lesivo cometido con dolo directo. Esta es una traslación incorrecta del esquema de análisis el robo con homicidio (en la hipótesis de "con motivo") al robo simple. Contra Marcelo Valdebenito San Martín, cit., nota 118; contra Daniel R. García Abarca, cit., nota 118.

122 Hurto y robo...cit., p. 128-133.
} 
Pese a su aparente razonabilidad material, esta explicación no brinda una solución dogmáticamente aceptable. Conforme a la tesis de Mera, una misma circunstancia -la existencia de una relación de crédito entre el autor de la apropiación y el ofendidofundamentaría la impunidad de la apropiación pura y simple (frente al hurto), se concretaría en un ostensible privilegio penal cuando la apropiación se comete mediante coacción menos grave (frente al concurso ideal entre hurto y coacción), pero no produciría efecto alguno en caso de robo. Semejante tesis sólo es aceptable si se postula para el robo una apreciación de lo injusto de la apropiación de cosa mueble ajena sustancialmente distinta del injusto del hurto. Pero una tal disociación de los tipos de injusto del hurto y del robo contradice todos los datos de lege lata del Derecho Penal chileno ${ }^{123}$.

Tal como lo ha sostenido Miguel Soto Piñeiro, la diferencia entre la autotutela ilícita y los delitos de apropiación, si es que existe, sólo puede fundarse en lo injusto del atentado a la propiedad ${ }^{124}$. Siguiendo a Bajo Fernández ${ }^{125}$, Miguel Soto desestima que el ánimo de pago pueda excluir al ánimo de lucro, sosteniendo que aquél no es más que una modalidad de éste. Esta tesis, que contradice lo sostenido por la doctrina y jurisprudencia tradicionales, me parece inobjetable. En cambio, me parece apresurado su rechazo de la apreciación de un menor disvalor de injusto del ánimo de hacerse pago.

Siguiendo también a Bajo Fernández, Miguel Soto niega que pueda verse en una apropiación de cosa mueble ajena no autorizada excepcionalmente por el Derecho privado, es decir, no cubierta por una causa de justificación en virtud de la metarregla del art. $10 \mathrm{~N}^{\circ} 10$ C.P., un desplazamiento del poder fáctico inherente a la condición de propietario que se encuentre conforme al orden jurídico de la propiedad.

Esta tesis es irrebatible respecto del acto de apoderamiento o sustracción, y por lo mismo de la coacción que sirve a su realización. Si lo injusto de la apropiación que suponen el hurto y el robo no consistiera más que en el atentado contra la posición jurídico-formal de propietario en su concreción fáctica (custodia), la crítica de Miguel Soto debería considerarse como irrefutable.

\footnotetext{
123 Por cierto que Jorge Mera está consciente de este reparo fundamental; él lo considera sin embargo como "una crítica equivocada" (op. cit., p. 131, nota 208). A su juicio, la relación entre los arts. 432 y $494 \mathrm{~N}^{\circ} 20$ debe postularse de modo tal que "cualquiera (incluso el acreedor) que sin la voluntad de su dueño y con ánimo de lucrarse se apropia de una cosa mueble ajena usando la violencia o intimidación en las personas o de fuerza en las cosas comete robo; si faltan la violencia, la intimidación y la fuerza, el delito se califica de hurto, a menos (...) que el sujeto activo sea el acreedor que se apodera sin violencia de una cosa perteneciente a su deudor para hacerse pago con ella" (ibidem). Pero esto es puro voluntarismo interpretativo. Y en este caso, Jorge Mera no puede recurrir a argumentos de justicia material para "rectificar" al legislador, porque ahora su discurso se ha transformado en una estrategia de incriminación: en la medida en que Mera pretende prescindir para el robo de un presupuesto de punibilidad del hurto infringe abiertamente el principio de legalidad.

124 Comentario a sentencia, en: Revista de Ciencias Penales Tomo XXXIX No 2 (1981-1989), p. 90 y ss. Los resultados a que arriba Miguel Soto me parecen inverosímiles, pues su tesis, en resumen, equivale a sostener que el Código Penal chileno habría configurado una hipótesis de robo calificadísimo, punible con presidio mayor en su grado máximo, mediante el expediente de establecer una disposición en el catálogo de las faltas. Con todo, aunque su parte constructiva no sea aceptable, en su parte analítica el comentario de Miguel Soto que en rigor es una extensa y muy documentada monografía- constituye sin duda la mejor contribución que se ha hecho entre nosotros a la dogmática de los delitos contra la propiedad.

${ }^{125}$ La realización arbitraria del propio derecho, Madrid, 1976.
} 
Pero si el bien jurídico protegido por la norma que sanciona el hurto y el robo es un contenido fáctico de poder correlativo a la posición jurídico-formal de propietario, entonces se necesita constatar alguna relevancia jurídica de ese contenido de poder como presupuesto del libre desarrollo de la personalidad del propietario. Este es precisamente el punto de vista desde el cual se puede justificar la apreciación de un disvalor sustancialmente menor, en la medida en que el derecho del acreedor comprenda concretamente todo el contenido de poder fáctico correspondiente a la posición jurídicoformal de propietario, de modo que al ofendido no le reste sino su pura condición formal de propietario $^{126}$.

Esta consideración permite fundamentar las conclusiones a que arriba Bajo Fernández, y que Miguel Soto rechaza, esto es, que se encuentran excluidos de los delitos de apropiación los casos en que el acreedor se apropia de dinero o de la especie o cosa, a cuya entrega tiene un derecho actualmente exigible ${ }^{127}$. Fuera de estos casos, el propietario mantiene un residuo de contenido fáctico de poder no contrarrestado por su obligación de entregar, como sucede por ejemplo con la facultad de escoger la cosa en caso de obligaciones de género (art. 1509 Código Civil) ${ }^{128}$. Respecto de todo este ámbito residual de poder subistente, los ataques a la custodia deben ser considerados como constitutivos de hurto o robo, según sus circunstancias de comisión.

Naturalmente, con lo dicho puede explicarse sólo la mitad de los problemas que plantea la existencia de la figura del art. $494 \mathrm{~N}^{\circ} 20$. No basta con fundamentar por qué en ciertos casos la apropiación de cosa mueble del deudor por parte del acreedor se encuentra excluida del sistema de los delitos de apropiación. Además hay que explicar cuál es el fundamento de injusto de la incriminación de la autotutela ilícita. El tratamiento de esta cuestión nos llevaría más allá de los límites de este artículo. Sin embargo, una breve reflexión servirá para mostrar que también aquí es pertinente tomar en consideración lo injusto de la coacción.

Dos son los modelos básicos de regulación de la autotutela que ofrece el Derecho comparado. Uno, característico de la codificación prusiana y alemana, es desconocer un lugar sistemático propio a la autotutela ilícita, dejando su incriminación entregada a la aplicación de los demás delitos integrantes del sistema de la Parte Especial. Esto significa que, para los casos en que la autotutela se encuentre excluida de los delitos contra la propiedad y el patrimonio, por regla general sólo restará como posible título de incriminación del delito de coacción. El otro modelo regulativo es el adoptado por la codificación italiana, que considera a la autotutela ilícita ("ejercicio arbitrario de las propias razones") como un atentado contra el orden de la administración de justicia, y le otorga un tratamiento exhaustivo y altamente diferenciado.

\footnotetext{
126 En este sentido, Samson, op. cit. [nota 5], \$242, núms. 85-86.

127 Bajo Fernández, op. cit., p. 41 y ss., 67 y ss. No puede negarse, eso sí, que a partir de las premisas defendidas por Bajo Fernández es mucho más coherente el rechazo que hace Miguel Soto de esta tesis que su defensa por el propio Bajo Fernández. La crítica de Miguel Soto es, en este sentido interno, contundente (op. cit., p. 113 y ss.).

${ }^{128}$ Lo cual demuestra, en todo caso, cuán impropia es la aplicación que la jurisprudencia hace del art. $494 \mathrm{~N}^{\circ}$ 20, extendiéndolo incluso a casos de apropiación mediante engaño del tercero detentador de una especie no debida para efectuar de propia mano o constreñir al pago de una deuda de dinero (Contra Sergio del Carmen Huerta Cornejo, Corte de Apelaciones de San Miguel, sentencia de 27 de Enero de 1995, en: Revista Gaceta Jurídica $\mathrm{N}^{\mathrm{o}} 175$, p. 132).
} 
La codificación española nunca ha adoptado un modelo inequívoco de regulación de la autotutela ilícita. Desde 1822, la legislación española ha previsto el caso específico del apoderamiento de cosa mueble ajena perteneciente al deudor en una norma especial, además de sancionar a título de coacción violenta el compeler a otro a ejecutar algo justo pero no querido por éste. Sin embargo, la consideración sistemática de la norma especial ha variado de época en época: "fuerza contra las propiedades" en el Código de 1822 (art. 810), "delito contra la libertad y seguridad" en los Códigos de 1848 (art. 411), de 1850 (art. 421), 1870 (art. 511), 1928 (art. 680) y 1932 (art. 489), y finalmente "delito contra la administración de justicia” en los Códigos de 1944 (art. 337) y 1995 (455). Bajo Fernández ha demostrado convincentemente que este solo supuesto típico está sin embargo muy lejos de proteger adecuadamente la administración de justicia ${ }^{129}$. La razón de ello radica en que, a pesar del cambio sistemático, el tipo en cuestión no ha dejado ser un caso especial de coacción violenta, en vez de transformarse en un sistema de hipótesis diferenciadas, semejante al italiano.

De lo anterior se desprende que la tesis más plausible para explicar la posición sistemática de la autotutela ilícita en el Código Penal chileno es hacer valer a su respecto la misma consideración válida para el Código Penal español de 1848/1850. Conforme a esta consideración, la ley chilena prescinde de considerar a la administración de justicia como un bien jurídico digno de protección penal en este contexto y remite en general la punición de la autotutela a las reglas de protección penal de la libertad personal, configurando una hipótesis especial de coacción violenta relacionada con el apoderamiento de cosa perteneciente al deudor para hacerse pago con ella. De este modo se eliminan de raíz todas las interrogantes acerca del bien jurídico protegido por esta figura y por el tratamiento de la intimidación y la amenaza como medios comisivos. La autotutela ilícita no es más que un caso nominado de coacción violenta (art. 494 No 16), y la comisión del hecho mediante amenazas coercitivas queda entregada al régimen general de protección penal de la libertad frente a la coacción mediante amenaza, es decir, a las normas sobre amenazas condicionales (arts. $296 \mathrm{~N}^{\circ} 1$ y 2,297$)^{130}$.

Por cierto que desde un punto de vista político-criminal resulta absurdo que la autotutela mediante violencia reciba un tratamiento penal más benigno que la autotutela mediante amenaza, y que en virtud de ello se produzca una diferencia abismal entre la autotutela coercitiva y la apropiación coercitiva, cuando se emplea la violencia como medio comisivo. Pero este absurdo se encuentra en la base misma de la protección penal de la libertad personal tal como se encuentra dispensada en el Código Penal chileno, y por lo mismo ninguna interpretación puede "rectificarlo" válidamente. A la demostración de esta aseveración se encuentra consagrada la primera parte de la próxima sección.

\section{La coacción como elemento de injusto del robo}

El rasgo más notorio del análisis del delito de robo que tradicionalmente ha efectuado la doctrina es su desconocimiento del concepto de la coacción como injusto típico autónomo dentro del sistema de la Parte Especial.

\footnotetext{
${ }^{129}$ La realización arbitraria...cit., p. 80 y ss.

130 De este modo, aunque discrepo en lo relativo a las consecuencias que ello traería para el sistema, coincido enteramente con Miguel Soto en que la mejor opción de lege ferenda al problema de la autotutela ilícita radica en la solución legislativa alemana: la derogación pura y simple del art. $494 \mathrm{~N}^{\circ} 20$.
} 
El análisis de la violencia como medio comisivo del robo que hace ya más de cuarenta años efectuó Jaime Vivanco finalizaba descomponiendo este concepto en una disyunción entre violencia típica a título de lesiones u homicidio y violencia atípica por la ausencia de un resultado de daño orgánico ${ }^{131}$. De aquí que Vivanco sostuviera que la muerte no es sino el grado máximo que puede alcanzar la violencia y que por lo mismo todo robo con homicidio es un robo con violencia. El análisis que hace Jorge Mera del sentido de los términos "violencia" e "intimidación" en el delito de robo reproduce el mismo esquema dogmático de Vivanco, pero invertido. En vez de partir del concepto de violencia en sí misma atípica como umbral mínimo del tipo básico, Mera parte del umbral máximo representado por la violencia homicida o gravemente lesiva, para sostener que el umbral mínimo debe definirse requiriendo una violencia que represente un peligro concreto de acaecimiento de semejantes resultados lesivos ${ }^{132}$. Así pues, la línea argumentativa abierta en 1954 se cierra simétricamente cuarenta años más tarde, manteniendo intacto en su núcleo el vacío representado por el desconocimiento de lo injusto de la coacción ${ }^{133}$.

En la sección anterior se demostró que la concepción moderna del robo como coacción subyace a la regulación chilena del tipo básico de robo, y que la mantención y desarrollo de esa concepción como premisa de análisis dogmático es indispensable para plantear e intentar resolver correctamente las diversas dificultades que plantea la aplicación de los arts. 433 y 436 del Código Penal. En esta sección se expondrá muy brevemente el horizonte de referencia de semejante análisis, es decir, las bases de la regulación de la coacción en el Código Penal chileno, y se demostrará que dicho horizonte permite

131 El delito...cit., p. 31 y ss. La consecuencia que Vivanco obtiene de este examen es que en el contexto del Código Penal el robo es parcialmente un delito complejo y parcialmente no lo es, en la medida en que la violencia ejercida en el caso concreto sea o no por sí misma constitutiva de delito (p. 35). Esta tesis demuestra que Vivanco no advierte que toda violencia constitutiva de robo en el sentido de los arts. 432 y 436 inciso primero C.P. es por definición -y como mínimo- coacción violenta tipificada en el art. $494 \mathrm{~N}^{\circ} 16$ C.P.

$132 \mathrm{La}$ adopción de este esquema de análisis se produce en Mera en términos explícitamente adversos a la concepción del robo como coacción. En sus palabras: "La incorporación de la libertad de actuación, como nuevo bien jurídico, integrante de la figura compleja del robo con violencia o intimidación simple, rompe la estructura y el sistema del Código en esta materia..." (Hurto y robo...cit., p. 137).

133 Este desconocimiento no es algo inusual en culturas jurídicas pertenecientes al mundo latino, históricamente influenciadas por el Código Penal de Napoleón. Que Jaime Vivanco no advirtiera la relación sistemática existente entre el robo y la coacción violenta se debió precisamente a este déficit heredado. La fuerza de esta inercia cultural se hace tanto más evidente si se tiene presente que Vivanco desconoció la relación entre robo y coacción a pesar de trabajar sobre la base de un concepto de violencia que había sido deliberadamente construido en el sentido de la coacción violenta por Carlos Leyton Garavagno, autor de una sobresaliente monografía sobre la extorsión, fuertemente influenciada a su vez por la doctrina de Sebastián Soler (El delito de extorsión, Santiago, 1953). En el tiempo transcurrido, el análisis del delito de coacción ha cobrado sin embargo una considerable importancia en el desarrollo de la dogmática de la Parte Especial por la doctrina española. La bibliografía básica es la siguiente: Angel Torío López, La estructura típica del delito de coacción, en: Anuario de Derecho Penal y Ciencias Penales, Tomo XXXI [1977], p. 19 y ss.; Santiago Mir Puig, El delito de coacciones en el Código penal, en: Anuario de Derecho Penal y Ciencias Penales, Tomo XXXI [1977], p. 269 y ss.; Juan Felipe Higuera Guimerá, El delito de coacciones, Barcelona, 1a. ed., 1978, 2a. ed., 1983; Antonio García Pablos de Molina, Sobre el delito de coacciones, en: Estudios Penales y Criminológicos, VI (1983), p. 103 y ss.; Javier Mira Benavent, El concepto de violencia en el delito de coacciones, en: Cuadernos de Política Criminal No 22 [1984], p. 965 y ss.; Elena Larrauri, Libertad y Amenazas, Barcelona, 1987; Miguel Bajo Fernández, El delito de coacciones, en: Estudios Penales en Memoria del Profesor Agustín Fernández-Albor, Santiago de Compostela, 1989, p. 57 y ss.; del mismo: El delito de amenazas, en: Criminología y Derecho Penal al Servicio de la Persona, Libro Homenaje al Profesor Antonio Beristain, San Sebastián, 1989, p. 649 y ss.; José Manuel Lorenzo Salgado, El delito de amenazas: consideraciones sobre el bien jurídico protegido, en: Estudios Penales en Memoria...cit., p. 439 y ss.; del mismo: Alcance y características del "mal" en los artículos 493 y 494 del Código Penal, en: Criminología y Derecho Penal...cit., p. 763 y ss. 
fundamentar de mucho mejor manera lo injusto material del delito de robo que el horizonte representado por la afectación de la seguridad de las personas.

\subsection{La posición de la coacción en el sistema de la Parte Especial}

Según Jorge Mera, existiría en el Código Penal un sistema en materia de violencia e intimidación susceptible de reconstrucción dogmática ${ }^{134}$. Este sistema reconocería una diferenciación en tres categorías, dependiendo de la función que cumplen estos medios en la estructura de los distintos tipos, las cuales pueden ser ordenadas en una relación de menor a mayor relevancia en la fundamentación del disvalor de injusto. La primera categoría corresponde a su función de medios comisivos especificados pero alternativos a otros medios comisivos 135 . La segunda, a su función como medios comisivos especificados y exclusivos ${ }^{136}$. La tercera categoría corresponde a la función agravatoria del empleo de esos medios en relación con algún un tipo básico ${ }^{137}$. De esta reconstrucción dogmática concluye Mera que por regla general el Código no considera que la violencia o la intimidación sean medios comisivos portadores de un plus de disvalor de injusto que trascienda el bien jurídico protegido. Esto, que es manifiesto en los casos en que ellas constituyen medios comisivos alternativos, se refleja también en la moderada penalidad asignada a los tipos que exigen su uso en la comisión de la acción, ya sea en el nivel del tipo básico o de las hipótesis agravadas. Tratándose de éstas últimas, lo moderado de la pena indicaría que el mayor disvalor de injusto del que son portadores la violencia y la intimidación tiene una dimensión muy reducida o marginal, que Mera identifica como la afectación del bien jurídico consistente en el sentimiento de seguridad o tranquilidad ${ }^{138}$.

Esta es una sistematización aparentemente razonable desde el punto de vista de la cuantía de la pena, pero que no resiste un examen dogmático riguroso. Si el sistema de la dogmática de la Parte Especial se basa en la identificación del bien jurídico, entonces el único punto de partida correcto para clasificar los supuestos típicos en que la violencia y la intimidación son medios comisivos es aquel que atiende a su correlación funcional a la lesión o puesta en peligro de un bien jurídico. Considerando el criterio del bien jurídico protegido, salta a la vista que existe una diferencia crucial entre algunos y otros delitos de violencia, según si son o no tipos de coacción, es decir, supuestos en los cuales el medio comisivo es un medio de afectación de la libertad personal, en el sentido de la estructura de injusto de los delitos contra la libertad ${ }^{139}$. Esta sola premisa determina la exclusión de

134 Hurto y robo...cit., p. 122 y ss.

135 A esta categoría pertenecerían el impedimento de ejercicio de funciones a la autoridad (art- 267) y la evasión de detenidos fuera del establecimiento (art. 301 inciso segundo) (op. cit., p. 127). La evasión de detenidos dentro del establecimiento (art. 301 inciso primero) pertenecería a una categoría mixta, ya que la violencia es equiparada al soborno pero en una función agravatoria.

136 A esta categoría pertenecerían el impedimento de ejercicio de un culto (art. 138), el atentado propio e impropio (arts. 261-262), el apoderamiento de oficinas telegráficas (art. 345), la coacción violenta (art. $494 \mathrm{~N}^{\circ}$ 16) y la autotutela ilícita (art. $494 \mathrm{~N}^{\circ}$ 20) (op. cit., p. 124-126).

137 A esta categoría pertenecerían el ultraje violento del ministro de un culto (art. 140), la rotura violenta de sellos (art. 271), la evasión violenta de detenidos (art. 301), el acometimiento violento del conductor de correspondencia (art. 341), la celebración violenta de matrimonios ilegales (art. 384) y la usurpación violenta de aguas (art. 460) (op. cit., p. 122-123).

138 Op. cit., p. 123.

139 Para una concepción liberal de la legitimación del ius puniendi, en un sentido político-criminal amplio todo delito es un delito contra la libertad, porque el libre desarrollo de la personalidad es el fin de la protección de todos los bienes jurídicos (supra, sección 2.6-a). En sentido dogmático estricto, sólo son atentados a la libertad personal -como presupuesto específico del libre desarrollo de la personalidad- las formas de interacción 
varias de las disposiciones legales examinadas por $\mathrm{Mera}^{140}$, y la inclusión de figuras no consideradas por él, como la violación, los abusos deshonestos coercitivos, la extorsión documental y, fundamentalmente, las amenazas condicionales.

La coacción y el engaño son las dos formas genéricas de interacción ilegítima ${ }^{141}$. Esta dualidad se expresa conocidamente en el derecho privado (a propósito, por ejemplo, de la posesión y los vicios del consentimiento), y, por cierto, en los delitos contra el patrimonio, donde da origen a la distinción entre extorsión y estafa. En la definición del sistema de los delitos contra bienes jurídicos personalísimos, sin embargo, la codificación europea del Siglo XIX rompió con este dualismo, tipificando como delito autónomo solamente la coacción ${ }^{142}$. Esta decisión sistemática encontró su justificación en el reconocimiento de la libertad personal como bien jurídico digno de protección penal autónoma ${ }^{143}$, consideración que obviamente no es de fácil aplicación al engaño.

La relación entre el tipo genérico de coacción (delito contra la libertad) y los tipos especiales de coacción (coacciones sexuales y patrimoniales, por ejemplo) no quedó por lo general establecida de un modo enteramente armónico en la obra legislativa del Siglo XIX, por la sencilla razón que las coacciones especiales tenían una tradición doctrinaria y legislativa de mucho mayor extensión y complejidad que la primera. En estricto rigor, la construcción de un auténtico sistema de relaciones normativas entre los distintos tipos de coacción ha sido obra de la dogmática post-codificatoria. El grado de elaboración sistemática de esta idea regulativa, así como la intensidad de su influencia en la política legislativa ha sido distinto en cada país europeo ${ }^{144}$.

coercitivas. En tanto libertad negativa, la libertad personal es ausencia de coacción.

140 Como todos los supuestos de acometimiento, en los cuales la violencia adquiere el carácter de maltrato de obra (vías de hecho), usualmente combinado con una significación denigratoria, en el sentido de la injuria de hecho. Tal es el caso paradigmático del ultraje al ministro del culto (art. 140) y de la hipótesis de acometimiento en el delito de atentado propio (art. $261 \mathrm{~N}^{\circ}$ 1). El "acometimiento" del art. 341, es, por el contrario, un delito de coacción. Existe un buen número de tipos delictivos en el Libro II del Código Penal respecto de los cuales no es seguro si la violencia es o no un medio coercitivo (así, por ejemplo, los arts. 271, $301,342 \mathrm{~N}^{\mathrm{o}}$ 1, 343,457, 460); en todos estos casos, la cuestión requiere una decisión interpretativa. Tratándose de la amenaza, por otra parte, existen casos manifiestos en que dicha acción no requiere tener el carácter de un medio coercitivo para realizar el tipo (arts. 264, $296 \mathrm{~N}^{\circ} 3$ ).

141 Tratándose de ciertos comportamientos, la promesa remuneratoria constituye otra forma de interacción ilegítima. Este es el caso de decisiones de funcionarios públicos, que se exige sean adoptadas atendiendo a una motivación basada en normas o razones normativas.

${ }^{142}$ La excepción que confirma la regla se encuentra en el delito de engaño (Täuschung) del $\int 108$ del Código Penal austríaco de 1974, que sanciona como delito contra la libertad personal y con pena privativa de libertad de hasta un año a "El que de propósito irrogue a otro un perjuicio en sus derechos, induciéndolo a él o a un tercero mediante engaño a una acción, tolerancia u omisión, la cual causa el perjuicio". Esta radical innovación legislativa austríaca nunca ha encontrado aceptación en la doctrina (al respecto, Kienapfel, Grundriß des österreichischen Strafrechts, Besonderer Teil, Band I, 1997, p. 280 y ss).

143 Reconocimiento que no fue fácil ni inmediato, sino que sólo se impuso después de un largo y arduo proceso de discusión político-criminal. En lo que respecta al reconocimiento de la coacción, supra, nota y las referencias ahí consignadas. Un vistazo general a algunas de estas dificultades puede encontrarse en Francesco Carrara, Programma...cit. [nota 13], Tomo II, IS 1558-1561.

144 En términos muy generales, se puede decir que la elaboración ha sido nula en Francia, máxima en Alemania y considerable en países como Suiza, Austria, Italia y España. Solo en Alemania, sin embargo, la elaboración de un sistema dogmático de los delitos de coacción ha dominado por completo el rumbo de la legislación. En el caso español, el Código Penal de 1995 está en este aspecto muy por debajo del nivel de desarrollo alcanzado por la doctrina. 
En lo que concierne al Código Penal chileno, la verdad es que ni siquiera puede afirmarse de él que consagre un sistema de regulación de la coacción. Por influencia de la codificación española, en el Código Penal chileno lo injusto de la coacción aparece regulado de un modo complejo, dividiéndose su contenido en dos estructuras típicas paralelas caracterizadas atendiendo al medio comisivo empleado. El empleo de violencia como medio coercitivo realiza el tipo de las coacciones violentas y el empleo de amenaza, el tipo de las amenazas condicionales ${ }^{145}$.

Lo peculiar del Código Penal chileno es que recoge la regulación española sin entenderla, dando con ello una prueba incontestable del carácter dependiente e irreflexivo del proceso de fijación del texto legal ${ }^{146}$. En efecto, a diferencia de su modelo español, el Código Penal chileno no incluye a estas figuras dentro del apartado sistemático de los delitos contra la libertad personal, el cual se encuentra por lo demás extravagantemente ubicado como tercer Párrafo del Título III, dedicado a los agravios inferidos a los derechos garantizados por la Constitución. Tampoco trata conjuntamente a las amenazas condicionales y las coacciones violentas, sino que considera a las primeras como simples delitos contra el orden y la seguridad públicos cometidos por particulares (Título VI, $\ 11$, arts. 296-298) y relega a las coacciones violentas a la categoría de una mera falta (art. 494 $\left.\mathrm{N}^{\mathrm{o}} 16\right)$.

En el derecho penal europeo del Siglo XIX no es inusual encontrar un tratamiento especialmente severo para la coacción mediante amenaza de cometer un delito. El caso más evidente es el de la codificación francesa, que como ya se ha visto se caracteriza por tipificar sólo esta hipótesis de coacción. No existe sin embargo otro caso como el chileno, que originalmente sancionó con todo el marco penal del simple delito, esto es, de sesenta y un días a cinco años de pena privativa de libertad- a la coacción mediante amenaza de un mal no constitutivo de delito (art. 297) y que al mismo tiempo decidió sancionar con pena de falta a la coacción mediante violencia (art. $494 \mathrm{~N}^{\circ}$ 16). Este absurdo sólo puede explicarse como un error, y carece por completo de justificación político-criminal ${ }^{147}$.

Así pues, en el Código Penal chileno no es tarea sencilla efectuar comparaciones de penas entre los distintos tipos de coacción. Primero hay que decidir qué marco penal es el que corresponde al tipo subsidiario de coacción, que es donde se encuentra el parámetro de comparación del sistema. Si se parte de la base que la pena de la falta de coacciones violentas es el producto de un error legislativo, y que por lo tanto no puede ser considerada dogmáticamente como expresión de la valoración del legislador, entonces sólo queda como posible parámetro la pena de la hipótesis menos grave de coacción

\footnotetext{
145 Esto significa que desde el punto de vista del sistema dogmático, las amenazas condicionales no son hipótesis especiales de amenazas, sino hipótesis alternativas de coacción. A la demostración de esta tesis, y a la derivación de las principales consecuencias que se derivan de esta reconstrucción racional del material legislativo español, se encuentra dedicado mi artículo sobre La regulación española de la coerción en el marco de la codificación europea, cit. [nota 29], especialmente p. 280 y ss.

${ }_{146} \mathrm{El}$ cual contrasta con el elevado nivel de reflexión demostrado, por ejemplo, por el sistema de la Parte Especial del Proyecto de Código Penal elaborado por Manuel Carvallo (Proyecto de Código Penal para la República de Chile, Santiago, 1859, arts. 396-403, p. 118-120). El examen de la regulación que Carvallo proponía para el delito de coacción puede suscitar objeciones en aspectos de detalle, pero inequívocamente demuestra que su autor comprendió el núcleo de injusto de la coacción y las relaciones sistemáticas existentes entre las amenazas condicionales y la coacción violenta.

147 Así, Miguel Soto, Comentario...cit., p. 99-100; Alfredo Etcheberry, op. cit., p. 245.
} 
mediante amenaza, es decir, del delito de amenaza condicional de mal no constitutivo de delito (art. 297), que como recién se expuso originalmente correspondía a todo el marco penal de la pena de reclusión aplicable a los simples delitos ${ }^{148}$.

La comparación de esta pena con las penalidades asignadas a los distintos tipos especiales de coacción del Libro II del Código Penal arroja un resultado no menos sorprendente por su irracionalidad. Sólo respecto de un reducido número de delitos se da la relación sistemática que sería esperable entre un tipo genérico o subsidiario de coacción y un tipo de coacción especial o preferente, que es la de conllevar éste último una moderada agravación de la penalidad ${ }^{149}$. En otro reducido grupo de delitos, si bien se mantiene la misma relación de agravación, ésta asume dimensiones desproporcionadamente severas ${ }^{150}$. Contra toda lógica, sin embargo, el mayor número de delitos especiales de coacción recibe una pena igual o inferior a la del art. 297; es decir, desde el punto de vista de su penalidad se trata de tipos privilegiados o superfluos de coacción ${ }^{151}$. ¿Qué "sistema" susceptible de "reconstrucción dogmática" puede tener un Código Penal marcado por tal nivel de irracionalidad?

El punto de partida honesto de la dogmática en esta materia sólo puede consistir en un reconocimiento inicial de la ausencia de racionalidad sistemática del derecho positivado. Únicamente a partir de este reconocimiento es que el discurso jurídico puede organizar en forma coherente las dos estrategias argumentativas que requiere la superación de este estado de cosas: reducir interpretativamente la irracionalidad de las consecuencias en la medida de lo que sea compatible con el sentido literal posible de las disposiciones legales y la voluntad manifiesta del legislador histórico, y proponer una reforma legislativa.

En todo caso, en lo que respecta al problema de la posición de apropiación coercitiva (robo) en el marco de los delitos especiales de coacción, de lo expuesto puede deducirse al menos tres consecuencias significativas.

En primer lugar, cabe señalar que la correcta comparación del robo con los tipos básicos o residuales de coacción demuestra que la magnitud de la brecha existente entre la desproporcionada penalidad del robo y la penalidad del umbral de punición de la coacción depende fundamentalmente de la irracionalidad con que el Código Penal chileno regula este umbral. La comparación entre el robo y la falta de coacciones violentas arroja un resultado que desde un punto de vista sistemático carece por completo de justificación. No es ese el caso, sin embargo, de la comparación entre el robo y los delitos de amenazas condicionales. El umbral mínimo de punición de la coacción mediante amenaza

\footnotetext{
148 La penalidad originaria ha sido recientemente reducida, eliminándose su grado máximo, por la Ley 19.659, de 27 de Diciembre de 1999. La reducción se explica en virtud de su explícita extensión a los casos de condición incumplida.

149 Arts. 341, 366 en relación con el art. 361 N 1, 384 C.P.. De considerárselos casos de coacción, también pertenecerían a esta categoría los delitos de los arts. 271 y $342 \mathrm{~N}^{\circ} 1$ C.P..

${ }^{150}$ En el texto originario del Código, esta posición la ocupaba solamente el delito de violación, al cual se agregaron en 1954 los delitos de robo y extorsión de documentos, y en 1995, la prostitución internacional coercitiva.

151 Reciben una misma pena privativa de libertad que la originaria del art. 297 los delitos de los arts. 126, 150 y 335 C.P., y una pena inferior, los delitos de los arts. 138, $139 \mathrm{~N}^{\circ}$ 1, 255, 261, 262, 272 C.P. Explícitamente superfluos como tipos de coacción son, finalmente, los delitos de los arts. 287, 457 y 460 C.P. Naturalmente, el carácter privilegiado o superfluo de este tratamiento sólo es postulable en relación con la coacción mediante amenaza. Tratándose de la coacción mediante violencia el defecto es el inverso, debido al carácter de falta del tipo genérico o subsidiario.
} 
corresponde a un marco penal considerable, y las hipótesis de coacción mediante amenaza grave (la consistente en irrogar un mal constitutivo de delito) reciben penas que incluso pueden ser consideradas como graves en el régimen de penalidades del Código. Cuando se tiene presente que la imposición de cualquier condición mediante amenaza de mal constitutivo de delito puede recibir hasta cinco años de reclusión, se puede entender que la pena de la imposición de condiciones especialmente intolerables para el legislador comience en los cinco años y un día de presidio. No cabe duda que ambas penalidades están expuestas a la crítica de lege ferenda, por excesivas. Pero ya no existe una brecha insondable entre ellas que haga sistemáticamente incomprensible de lege lata sus relaciones recíprocas.

La actual posición del robo es, pues, la de un crimen de coacción. Desde un punto de vista sistemático de lege ferenda, ciertamente que lo razonable sería que las coacciones graves no recibieran más que el tramo superior de penalidad del simple delito. De lege lata, sin embargo, no se puede negar que el legislador ha decidido asignar a algunos delitos de coacción la calidad de crímenes. Esta categoría no se reduce solamente a las dos coacciones patrimoniales, el robo y la extorsión documental. También tratándose de las coacciones sexuales el legislador ha asignado el rango de crimen a algunos supuestos. Tal es el carácter, desde los orígenes del Código, del delito de violación, y desde hace pocos años también del delito de proxenetismo internacional coercitivo ${ }^{152}$.

Por último, es imprescindible constatar que en el texto originario del Código Penal los delitos de robo y extorsión documental no presentaban el problema sistemático de una desproporcionada agravación de la pena. Originariamente, el robo y la extorsión documental pertenecían a aquel reducido grupo de coacciones especiales racionalmente tratadas en relación con el tipo residual de coacción de su Libro II, pudiendo incluso decirse de ellos que parcialmente pertenecían al grupo mayoritario de los delitos privilegiados de coacción. Tal como se señaló más arriba, el sistema de penalidades originario del delito de robo distinguía tres supuestos, atendiendo al valor de la cosa apropiada, cuyas penas eran menos severas que la del art. 297 en uno de ellos, y moderadamente más severas en los otros dos. La decisión de considerar todo caso de robo como un crimen, asignándole la severa penalidad de todo el marco de la pena de presidio mayor, y todas las dificultades prácticas y distorsiones valorativas que de ello se derivan, fue obra de la Ley 11.625153.

\footnotetext{
152 Arts. 361 y 367 bis, introducido este último por la Ley 19.409 (1995). En las coacciones sexuales el legislador incurre en el error adicional de no diferenciar suficientemente la penalidad atendiendo a los distintos medios comisivos. Sólo los medios propios del estupro (actual art. 393, aplicables a los abusos sexuales del art. $366 \mathrm{~N}^{\circ}$ 2) reciben un tratamiento diferenciado de la coacción grave (fuerza e intimidación). Pero el abuso de la incapacidad de resistencia o de autodeterminación sexual, que exige también un tratamiento diferenciado, es sometido al mismo régimen regulativo que la coacción grave. Esta distorsión sistemática alcanza su paroxismo tratándose de la violación de impúberes, que recibe una penalidad incluso superior, sin que para ello sea necesario otro requisito que la realización de la acción sexual.

153 Supra, sección 2.5. Las penas originarias del Código fueron aumentadas por la Ley 3.988 (1923), que estableció para el supuesto de mayor valor la pena de presidio menor en su grado máximo a presidio mayor en su grado mínimo, la de presidio menor en sus grados medio a máximo para el supuesto de valor intermedio, y para el supuesto de menor valor, la de presidio menor en sus grados mínimo a medio. Los valores que determinaban la penalidad fueron a su vez modificados después por el Decreto Ley $\mathrm{N}^{\circ} 26$, de 1932, y la Ley 5.507, de 1934. Como se puede apreciar, hasta la entrada en vigencia de la Ley 11.625, en 1954, el robo y la extorsión documentales constituían delitos graves de coacción racionalmente tratados por el Código. En otras palabras, de los 127 años de vigencia del Código Penal chileno, 80 corresponden a una regulación más bien racional que irracional del delito de robo desde el punto de vista de la penalidad aplicable.
} 
Desde todo punto vista, en consecuencia, la consideración del robo como coacción permite asignarle una posición determinada en la mejor reconstrucción racional posible de la Parte Especial del Código Penal chileno.

\subsection{El robo como coacción grave}

Afirmar desde la teoría de los delitos de apropiación que el robo es coacción, implica al mismo tiempo afirmar desde la teoría de los delitos de coacción que es una coacción grave. Esta condición debe concretarse en la interpretación de las respectivas disposiciones legales. Un obvio elemento de lo injusto donde se concreta ese mayor disvalor es la expropiación o pérdida del contenido fáctico de poder sobre la cosa, que es correlativa a la apropiación. A la restricción de la libertad personal que es resultado de la coacción se suma la afectación del libre desarrollo de la personalidad que es producto de la pérdida del poder sobre la cosa. La posición mayoritaria de la doctrina española y alemana no se satisface con esa sola concreción, sino que exige además su expresión en el nivel de los medios coercitivos. Así, el robo es coacción grave por ser una coacción de medios comisivos calificados. No cualquier violencia o amenaza coercitiva realiza el tipo del robo, sino sólo aquella que es portadora de un disvalor especialmente grave.

Aquí hay un punto de conexión evidente con la teoría de Jorge Mera. Sin embargo, la perspectiva que escoge este autor para identificar esa mayor gravedad presupone la incorporación de elementos ajenos a la estructura de injusto del robo. Tratándose de una estructura compleja integrada por lo injusto del hurto y lo injusto de la coacción, la gravedad de un medio comisivo debe determinarse atendiendo a aquella parte de lo injusto con la cual dicho medio se encuentra funcionalmente relacionado. Por ello, la gravedad de un medio coercitivo debe determinarse en relación con el contexto de lo injusto de la coacción, es decir, en relación con la gravedad de la lesión a la libertad. Esta determinación se sujeta a argumentos de distinta naturaleza, según si se trata de la intimidación o de la violencia.

\section{a. La intimidación como amenaza coercitiva grave.}

La concreción de una especial gravedad es fácil en el marco de la coacción mediante amenaza ${ }^{154}$. Es un hecho conocido de la doctrina jurídica que la vis compulsiva es una cuestión de grado, de cuyo ejercicio se puede predicar que tiene mayor o menor intensidad en el caso concreto. La forma más precisa de determinar esa intensidad es relacionando la magnitud del mal con cuya irrogación se conmina con la proximidad del tiempo de la irrogación conminada. La vis compulsiva es más grave mientras mayor sea el mal conminado y menor sea el tiempo que se deja al coaccionado para decidir entre acceder a las exigencias del coaccionador o soportar el mal, siempre que haya un lapso mínimo.

En virtud de estas consideraciones, la doctrina dominante exige para realizar el tipo del delito de robo que la amenaza consista en el anuncio de la inminente irrogación

\footnotetext{
154 Por "amenaza" en el marco de lo injusto de la coacción se entiende todo anuncio de un mal cuya irrogación se presenta como dependiente de la voluntad del coaccionador, la cual se presenta a su vez como subordinada al comportamiento del coaccionado. La amenaza así definida incluye no sólo el anuncio de un mal de irrogación en un tiempo diferido, sino también el de un mal de inminente irrogación e incluso el de prolongación o reanudación de una irrogación que ya se ha comenzado a realizar o que se ha realizado.
} 
de la muerte o de un atentado grave a bienes relevantes, como la incolumidad personal (lesiones), la autodeterminación sexual (violación, abusos deshonestos de consideración) o la libertad personal (secuestro, sustracción de menores) ${ }^{155}$. Por el contrario, desde el punto de vista de la gravedad de la afectación de la libertad no tiene importancia alguna que el coaccionador tenga la sincera intención de irrogar el mal y cuente con la posibilidad efectiva de hacerlo. La "seriedad" y "verosimilitud" de la amenaza, exigidas expresamente por el art. 296, deben apreciarse desde la perspectiva del coaccionado, siempre que ésta sea reconocible para el coaccionador. El miedo inducido mediante engaño es temor y no error.

Este es el núcleo de la discrepancia de Jorge Mera con la doctrina dominante. Según Mera, esta es una interpretación puramente subjetiva del término intimidación que no satisface las exigencias materiales de disvalor que reclama el robo. Los argumentos esgrimidos por Mera son básicamente tres: (a) la tesis de que sólo un peligro concreto para la vida o la incolumidad personal (ahora se agrega además la consideración de la autodeterminación sexual y la libertad ambulatoria) puede servir de fundamento material de lo injusto del robo, (b) la tesis de que el tipo básico debe ser interpretado en consonancia con los tipos calificados, y (c) la invocación de criterios adicionales de fundamentación valorativa, dogmática y político-criminal. Por su importancia, los dos primeros argumentos serán examinados más adelante con mayor detenimiento (infra, 4.3 y 4.4 , respectivamente).

El principal de los criterios adicionales de fundamentación de la tesis consiste en aducir que lo injusto de la coacción no es suficientemente relevante como para fundamentar materialmente lo injusto del robo. En palabras de Jorge Mera:

“...la libertad de actuación es un bien jurídico que goza de escasa protección penal, a título de falta, y siempre que se use la violencia. (...) Aunque se entendiera comprendida en esta hipótesis [i.e. la del art. $494 \mathrm{~N}^{\circ}$ 16] (...) el empleo de intimidación, lo cierto es que el derecho a la autodeterminación, esto es, a la libertad de actuación, tiene, en el sistema del Código Penal, una jerarquía notoriamente inferior a la de otros bienes juzgados más relevantes por el legislador, como son la integridad corporal y la vida. De ahí que resulta inadmisible sostener que un empleo de la intimidación que afecte sólo a la libertad de actuar tenga la misma significación que el uso de una violencia, o, en su caso, intimidación, que comprometan la seguridad física de una persona." 156

Este argumento se compone de dos enunciados, uno de los cuales es falso y el otro, falaz.

155 Vid. supra, nota 3. En la formación de la postura dominante de la doctrina española ejerció una considerable influencia el análisis que Enrique Gimbernat Ordeig hizo de la intimidación como medio comisivo de la violación (Sobre algunos aspectos del delito de violación en el Código Penal español, con especial referencia a la violación intimidatoria, en: Anuario de Derecho Penal y Ciencias Penales, Tomo XXII (1969), págs. 489 y ss. ).

156 Hurto y robo...cit., págs. 138-139; en sentido similar, págs. 118-119. 
Es falso que la medida del disvalor de injusto de la coacción en el Código Penal chileno sea la pena asignada a la falta de las coacciones violentas. Paralelas a esta figura se encuentran las hipótesis de amenazas condicionales. Tratándose del robo con intimidación, es obvio que el tipo de recogida de coacción se encuentra en éstas, cuya penalidad expresa un considerable disvalor de injusto para la coacción mediante amenaza.

Por otra parte, es una falacia deducir del menor disvalor relativo de la libertad como bien jurídico su incapacidad para fundamentar lo injusto del robo. Pues si bien es cierto que en el sistema del Código Penal la lesión a la libertad personal que es típica de la coacción no tiene el mismo disvalor que tiene la lesión a la vida y que puede alcanzar la lesión a la incolumidad personal, de ello no se deduce que la lesión a la libertad tenga menor disvalor que cualquier lesión a la incolumidad personal o que el peligro para la vida o la incolumidad personal. Sólo la equiparación de los grados menos intensos de lesión y la mera puesta en peligro de esos bienes a su lesión masiva podría justificar la inferencia. Pero tal equiparación no es posible en el contexto del Código Penal chileno.

Más adelante se demostrará esto, en relación con el peligro para la vida y la incolumidad personal. Por el momento basta con observar que la comisión de coacción mediante amenaza (amenazas condicionales) conlleva una pena incomparablemente más severa que la comisión de lesiones menos graves, conducta ésta que Mera no obstante admite como constitutiva de violencia en el sentido del delito de robo. Así pues, no sólo es posible sino además enteramente correcto sostener que en el contexto del Código Penal chileno la lesión a la libertad que es típica de la coacción es en general portadora de un mayor disvalor de injusto que la mera puesta en peligro de la vida o la incolumidad personal.

Es sumamente expresivo que en las páginas que Jorge Mera dedica al examen de la intimidación como medio comisivo no identifique a las amenazas condicionales como tipo de recogida de la coacción mediante amenaza. El único vestigio de esta relación normativa-que es un aspecto crucial de la regulación española y francesa- se encuentra en la mención que Mera hace de la posibilidad de una relación concursal entre hurto y amenazas o coacción, idea que es adoptada de una formulación de Juan Bustos Ramírez, pero sin incorporar todo el trasfondo que ella tiene en el pensamiento de este autor ${ }^{157}$.

La negativa de Jorge Mera a reconocer en la coacción un concreto disvalor de injusto alcanza su máxima expresión en su postulación del "sentimiento de seguridad y tranquilidad" como un bien jurídico cuya afectación por el uso de intimidación sí debería dar lugar a la estimación de una agravante para el hurto ${ }^{158}$. Cualquiera que sea el mérito de lege ferenda que pueda darse a esta opinión, lo cierto es que ella expresa -inequívocamentela valoración opuesta a la que fue determinante en la codificación francesa, española y chilena en materia de amenazas.

Si la amenaza condicional tiene una pena más severa que la amenaza simple, y si son punibles amenazas condicionales que son impunes como amenazas simples, ello se debe única y exclusivamente al mayor disvalor que representa el agregado de la condición,

157 Op. cit., págs. 134 (nota 212), 135 y 139. A diferencia de Mera, Bustos Ramírez inequívocamente identifica a la libertad personal ("libertad de actuación", en su terminología) como el bien jurídico protegido en las amenazas condicionales (Manual de Derecho Penal-Parte Especial, 2a ed. [1991], pág. 96).

158 Op. cit., págs. 135, 140. 
o sea, del constreñimiento del comportamiento ajeno. Así pues, la propia estructura de las amenazas demuestra que para el derecho positivo la lesión a la libertad (resultado de coacción = condición impuesta) es un elemento de injusto comparativamente mucho más relevante que la afectación de cualquier otro bien jurídico que se considere como el objeto de protección en la amenaza simple ${ }^{159}$.

Tampoco el sistema de los delitos contra la propiedad y el patrimonio puede brindar el apoyo dogmático que Jorge Mera invoca para su tesis de la irrelevancia de la lesión a la libertad personal. A juicio de Mera, la penalidad de los fraudes y los abusos de confianza demostraría que el uso de estos medios no trasciende el ámbito puramente patrimonial. La lesión a la libertad mediante intimidación debe ser considerada como equivalente a la lesión a la libertad mediante engaño y al abuso de confianza ${ }^{160}$.

$\mathrm{Al}$ respecto, cabe señalar, en primer lugar, que las comparaciones entre los delitos de apropiación (hurto, apropiación indebida, robo) y los delitos de defraudación (estafa) no son sencillas. En particular, no puede ponerse en un mismo plano de comparación con el hurto una conducta de apropiación no consentida, como la apropiación indebida, y otra de disposición viciada por el engaño, como la estafa. Que la apropiación de cosa detentada fiduciariamente tenga la misma pena que el hurto es algo enteramente lógico: el abuso de confianza que supone aquella es el equivalente a la ruptura de la esfera de custodia que supone éste ${ }^{161}$. En cambio, la determinación de la pena de la estafa no tiene por qué homologarse a la del hurto ni a la de la apropiación de cosa detentada fiduciariamente.

Tal como arriba se dijo (supra, 3.1), en la estafa-de-cosa hay un acto de disposición que es precisamente lo que falta en el hurto. El régimen de incriminación de la estafa no ha de compararse con el del hurto, sino con el régimen de la extorsión. En el derecho comparado, esta confrontación demuestra que en el ámbito de los delitos patrimoniales el engaño es desvalorado como forma ilegítima de interacción, equiparándoselo al grado menos grave de la coacción patrimonial. Esto sucede de un modo peculiar en el Código Penal chileno, en el cual la penalidad de la estafa se mueve dentro de un marco penal que es común al de las amenazas condicionales, que, como también se dijo, constituye la sede de incriminación de la extorsión genérica o residual en el sistema de la codificación española y por lo tanto de nuestro Código ${ }^{162}$. Si algo puede deducirse, pues, de la obligada comparación entre extorsión (amenaza condicional) y estafa, es que para el Código Penal chileno la coacción mediante amenaza tiene tanto disvalor autónomo de injusto que absorbe el perjuicio patrimonial, mientras que el engaño sólo es punible en función de la lesión del patrimonio.

\footnotetext{
${ }^{159}$ No deja de ser paradojal, por otra parte, que Mera impugne la interpretación mayoritaria de la intimidación por su carácter subjetivo, para terminar postulando, en relación con la dimensión de injusto de la amenaza (intimidación), una concepción radicalmente subjetiva de la seguridad como bien jurídico (al respecto, vid. Lorenzo Salgado, El delito de amenazas...cit. [nota 121]).

160 Op. cit., págs. 137-138.

161 Desde un punto de vista sistemático, el hurto y la apropiación cometida con abuso de confianza son dos supuestos agravados de la simple apropiación, es decir, de aquella que no supone tenencia fiduciaria ni ruptura de la esfera de custodia ajena. El déficit chileno en esta materia -heredado de la regulación española- es precisamente el desconocimiento de la noción básica o simple de apropiación. Por su complicada y defectuosa construcción, el hurto de hallazgo (art. 448) ratifica en vez de compensar esta deficiencia.

162 Vid. supra, notas 55 y 80.
} 
En suma, la intimidación del robo no es sino coacción mediante amenaza. Es razonable entender que el contexto del robo requiera una coacción grave. Pero esa gravedad debe determinarse en función de la propia naturaleza de la intimidación, es decir, conforme a la intensidad de la lesión a la libertad personal163. A la luz de la regulación de las amenazas condicionales, es evidente que la lesión intensa de la libertad personal producto de la comisión la coacción mediante amenaza tiene un considerable peso específico como injusto material. Ese es el plus que fundamenta el injusto del robo frente al injusto del hurto. Desconocer esto es el error de Jorge Mera.

A pesar de su falta de fundamento, la tesis de Mera ha encontrado una importante acogida en una línea jurisprudencial desarrollada por Carlos Künsemüller Loebenfelder en su desempeño como abogado integrante de la Iltma. Corte de Apelaciones de San Miguel ${ }^{164}$. El argumento central de esta línea jurisprudencial corresponde a la idea principal de Jorge Mera, esto es, considerar que la pluriofensividad del robo exige constatar una puesta en peligro concreto de la vida, la incolumidad personal, la autonomía sexual o la libertad ambulatoria del destinatario de la amenaza. Como ya se ha dicho, este argumento será discutido más adelante (infra, 4.3). Aparte de este argumento, la jurisprudencia referida esgrime otras dos razones, cuya incorrección conviene demostrar inmediatamente ${ }^{165}$.

163 Esta es por lo demás la forma sistemática en que se expresa el robo en relación con la extorsión en la regulación más diferenciada del derecho penal europeo, que es la alemana: tanto el robo ( $\left.\int 249\right)$ como la extorsión calificada $(\$ 255)$ se distinguen de la extorsión simple $(\$ 252)$ por la naturaleza calificada de sus medios coercitivos.

${ }^{164} \mathrm{La}$ tesis jurisprudencial fue primero expuesta por Carlos Künsemüller en su voto de prevención en Contra Juan L. Guzmán Henríquez, sentencia de 30 de Marzo de 1995, en: Revista Gaceta Jurídica No 178 (1995), p. 146-160, y luego en su voto disidente en la sentencia de la misma Corte de 27 de Septiembre de 1995 (sin designación del condenado), en: Revista Gaceta Jurídica No 183 (1995), p. 123-127. Posteriormente, la tesis pasó a ser avalada por la Corte: contra Alfonso Contreras Ramírez, sentencia de 24 de Junio de 1996, en: Revista Gaceta Jurídica No 192 (1996), p. 126-131; contra Carlos Antonio Soto González, sentencia de 16 de Enero de 1997, en: Revista Gaceta Jurídica No 199 (1997), p. 146-148; Contra Marcela Acevedo Elgueta y otra, sentencia de 27 de Junio de 1997, en: Revista Gaceta Jurídica No 204 (1997) p. 158-161; Contra Ricardo Sarmiento Basoalto, sentencia 9 de Septiembre de 1997, en: Revista Gaceta Jurídica No 207 (1997), p. 151-153; Contra Claudio A. Vera Aguilera, sentencia de 19 de Noviembre de 1998, en: Revista Gaceta Jurídica No 221 (1998), p.158-160; contra Javier A. Muñoz. Mancilla, sentencia de 10 de Marzo de 2000, en: Revista Gaceta Jurídica No 237 (2000), p.130-133; contra Jaime Andrés Moraga Muñoz, sentencia de 23 de Enero de 2001, en: Revista Gaceta Jurídica ${ }^{\circ}$ 248 (2001), p. 231-235; contra Eduardo A. Parra Morales y otra, sentencia de 18 de Abril de 2001, en: Revista Gaceta Jurídica No 251 (2001), p. 149-152. Durante este desarrollo, ha habido naturalmente ocasiones en que la tesis sostenida por Künsemüller no ha logrado la adhesión del tribunal, originando votos de prevención en defensa suya: Contra Luis Manuel Salfate Salfate, sentencia de 27 de Diciembre de 1999, en: Revista Gaceta Jurídica $N^{\circ} 234$, p. 140-141 y el importante caso sin designación del condenado correspondiente a la sentencia de 9 de Junio de 2000, en: Revista Gaceta Jurídica No 239 (2000), p. 147-150. Aunque sin una argumentación densa, la Iltma.. Corte de Apelaciones de Santiago ha sostenido ocasionalmente una interpretación similar a la defendida por Mera y Künsemüller: Contra Mario del Tránsito Peralta González, sentencia de 24 de Octubre de 1988, en: Revista de Ciencias Penales XLII (1990-1994), Vol. 3, p. 116-117; Contra Hernán Orrego Morales, sentencia de 23 de Octubre de 1998, en: Revista Gaceta Jurídica No 220 (1998), p. 115-116; Contra Ricardo A. Veas Pacheco, sentencia de 9 de Marzo de 2001, en: Revista Gaceta Jurídica No 249 (2001), p. 140.

165 Aparte de estos argumentos interpretativos, en no pocos casos desempeña un considerable papel la falta de prueba suficiente en orden a la acreditación de la intimidación. En Contra Juan L. Gužán Henríquez, cit., nota anterior, p. 146, las consideraciones probatorias fueron el único argumento del voto de mayoría; en los restantes casos en que aparecen esas consideraciones se unen a ellas los argumentos interpretativos. Demás está decirlo, el uso de las unas y de los otros, simultáneamente, es inconsistente. Esa inconsistencia demuestra la auténtica motivación de esta línea jurisprudencial: evitar la aplicación de la pena del robo simple con cualquier excusa. Esto se manifiesta también en el oscilante criterio seguido por la Corte y por Carlos Künsemüller para calificar el hecho cuya calidad de robo se niega: hurto en algunos casos y robo por sorpresa en otros, sin que haya justificación para la variación. Ambas calificaciones son por lo demás erróneas: los casos 
Una primera razón es la tesis de la equiparación a la violencia, particularmente importante en las primeras sentencias ${ }^{166}$, pero en todo caso aún vigente en las últimas ${ }^{167}$. Este argumento consiste en constatar que la intimidación es un medio comisito alternativo a la violencia, postular que esa condición exige atribuirle una gravedad e intensidad semejantes a las de la violencia, y deducir de este requisito que la intimidación debe consistir en una amenaza que cree un peligro concreto para bienes jurídicos personalísimos. Este razonamiento no es concluyente.

El dato legal del que parte el argumento es indesmentible. Pero la equiparación que en su virtud corresponde exigir entre la violencia y la intimidación es la funcional, tal como lo demuestra el art. 439: una y otra se equiparan en tanto medios de coacción ${ }^{168}$. También es razonable, por la condición de crimen del robo, exigir "gravedad e intensidad" en ambos medios comisivos, o sea, en ambas modalidades de coacción. Pero no hay razón alguna que justifique la exigencia de peligro concreto. La tesis de que sólo una amenaza que implique un peligro objetivo para bienes jurídicos personalísimos, distintos de la propiedad, puede fundamentar el robo pasa por alto que toda amenaza coercitiva efectiva implica ya la lesión de un bien jurídico personalísimo distinto de la propiedad, como es la libertad. No se requiere sino esa lesión de la libertad para fundamentar lo injusto del robo.

La otra razón es la tesis de la insuficiencia de la mera subjetividad del ofendido. Este argumento fue esgrimido en las primeras sentencias de esta línea jurisprudencial ${ }^{169}$, pero ha sido en su fase posterior que ha adquirido auténtica relevancia ${ }^{170}$. El argumento consiste en sostener que no basta con atender a los estados mentales del coaccionado para estimar realizado el tipo del robo, sino que se requiere constatar la idoneidad o efectividad de la amenaza como peligro objetivo. De nuevo se trata de una deducción apresurada

Es evidente que los meros estados mentales del ofendido no son fundamento suficiente de la punibilidad del robo. Pero la razón de ello radica en que esos estados

deberían ser calificados como amenazas condicionales, de condición cumplida o incumplida según si la imputación objetiva del resultado coercitivo pueda o no tenerse por acreditada. Finalmente, en el caso reciente en que el voto de mayoría de la Corte no aplicó la tesis de Mera y Künsemüller esta variación de criterio sólo se explica en función de la gravedad de la apropiación: el objeto era aquí un automóvil, en vez de pertenencias personales portadas por la víctima (sentencia de 9 de Junio de 2000, sin designación del condenado, cit., nota 164, p. 147). Como se puede ver, se trata de una jurisprudencia crudamente orientada a las consecuencias.

166 Contra Juan L. Guzmán Henríquez, cit., nota 164, cons. 16 del voto de prevención, p. 150; sentencia de 27 de Septiembre de 1995, sin designación del condenado, cit., nota 164, cons. 1-1) del voto disidente, p. 126-127; contra Alfonso Contreras Ramírez, cit., nota 164, cons. $9^{\circ}$-o), p. 129; contra Carlos Antonio Soto González, cit., nota 164, cons. $9^{\circ}$ y $10^{\circ}$, p. 147; Contra Marcela Acevedo Elgueta y otra, cit., nota 164, cons. 10 y 11, p. 160; Contra Ricardo Sarmiento Basoalto, cit., nota 164, cons. 13, p. 152; contra Claudio A. Vera Aguilera, cit., nota 164, cons. $10^{\circ}$, p. 159; contra Luis Manuel Salfate Salfate, cit., nota 164, cons. $3^{\circ}$, p. 140; contra Javier A. Muñoz Mancilla, cit., nota 164, cons. 11, p. 132.

167 Contra Eduardo A. Parra Morales y otra, cit., nota 164 , cons. $4^{\circ}$, p. 149.

168 Uno de los rasgos más curiosos de esta línea jurisprudencial es que en su evolución ha reconocido el carácter coercitivo de la intimidación, calificándola explícitamente de "coacción", pero nunca ha advertido que también la violencia es coacción en el contexto del robo. De aquí que en un plano puramente conceptual sea inconsistente la tesis de que la coacción debe igualar en gravedad a la violencia. Conceptualmente, lo correcto es sostener que la intimidación debe equipararse a la violencia como medio alternativo de coacción.

169 Contra Juan L. Gurmán Henríquez, cit., nota 164, cons. 11 del voto de prevención, p. 148; sentencia de 27 de Septiembre de 1995, sin designación del condenado, cit., nota 164, cons. 1-g), p. 125.

170 Sentencia de la Corte de Apelaciones de San Miguel, de 9 de Junio de 2000, sin denominación, cit., nota 164, cons. 12 del voto de prevención, p. 149; contra Jaime Andrés Moraga Muñoz, cit., nota 164, cons. 11 a 14, p. 232-233. 
mentales deben ser objetiva y subjetivamente imputables al coaccionador. Los estados mentales del coaccionado deben ser conocidos o haber sido previstos por el coaccionador, y éste debe además haberlos producido (o no evitado, en la eventualidad de aceptarse la comisión por omisión). Adicionalmente, cabe plantear la cuestión de cuál sea la intensidad del efecto coercitivo requerido, a la luz de un principio de autonomía y/o de la exclusión de la coacción de bagatela, y de si la solución a esa cuestión se obtiene mediante criterios generalizadores o individualizadores. Pero en ningún caso se deduce de lo anterior la necesidad de que el amenazado se encuentre en una situación de peligro concreto para sus intereses.

La oposición "subjetivo"-“objetivo" que esgrime retóricamente esta tesis es también refutable. Una acción de coacción mediante amenaza que logra constreñir la voluntad del coaccionado implica una lesión de su libertad. No es un resultado que tenga necesariamente una dimensión corporal, pero eso no lo hace menos objetivo. La coacción mediante amenaza es un fenómeno comunicacional, y en esa medida una cuestión de sentido. En tanto sea intersubjetivamente reconocible, es una cuestión objetiva.

Finalmente, es obvio que los requisitos de "idoneidad" y "efectividad" de la amenaza, exigidos por esta tesis, no tienen un sentido pretederminado. Qué cuente como idóneo o efectivo depende de cuál sea el fin perseguido. Cuando una amenaza es un medio de coacción, su idoneidad y efectividad se miden en función de su adecuación para producir ese resultado de coacción. Una amenaza atemorizante es coercitivamente idónea y efectiva. Y eso es todo lo que cuenta, cuando se entiende que el robo es coacción.

Tal como lo sostuvo el voto de mayoría de la Iltma. Corte de Apelaciones en la ocasión en que no se plegó a la tesis de Mera y Künsemüller,

“el carácter de arma de fogueo del objeto empleado por el reo para amenazar no le quita el carácter de medio idóneo para coaccionar su voluntad, y por ende, para obtener la apropiación de cosas ajenas sin el consentimiento de su poseedor"171.

\section{b. La violencia en las personas como violencia coercitiva grave.}

La coacción mediante violencia no admite con la misma facilidad que la coacción mediante amenaza la postulación de un régimen diferenciado entre casos graves y casos menos graves atendiendo a la intensidad de la lesión a la libertad. Es también un hecho conocido de la doctrina que la vis absoluta no admite graduación, sino que su ejercicio da lugar más bien una cuestión de todo o nada: o bien hay supresión de la capacidad de formación o de ejecución de la voluntad, o bien no hay coacción en relación con el resultado perseguido. De aquí que los intentos de la doctrina por restringir en el robo el ámbito genérico de la violencia coercitiva a un espectro reducido de violencia gravemente coercitiva adopten criterios diversos, todos ellos más o menos arbitrarios en relación con la consideración funcional de la violencia, sin que ninguno se haya convertido en dominante. Por esta razón, es en este punto donde más cercanía puede existir entre la tesis

171 Sentencia de la Corte de Apelaciones de San Miguel, de 9 de Junio de 2000, sin denominación, cit., nota 164, cons. $1^{\circ}$, p. 147. 
de Mera y cualquier tesis interpretativa restrictiva del concepto de violencia que se base en la concepción del robo como coacción.

Desde una perspectiva sistemática, lo más importante es cerrar el paso en el nivel de los delitos de coacción grave a los desarrollos más extremos del proceso de interpretación extensiva del concepto de violencia, al que también se denomina "desmaterialización" o "espiritualizacion" de dicho concepto, que ha tenido lugar en el contexto del tipo genérico de coacción ${ }^{172}$. Para este propósito, se debe asignar estipulativamente a la expresión "en la persona", que adjetiva a la violencia como medio comisivo del robo, el sentido de excluir aquellas formas de violencia que no inciden en la capacidad personal -corporal- de actuación, sino en la capacidad instrumental o en las condiciones del medio ambiente en que se desenvuelve su acción ${ }^{173}$. Con esta prevención quedan excluidos del ámbito del robo los casos de vis absoluta intuitivamente más discutibles como coacción violenta (supresión de la capacidad instrumental de ejecución de la voluntad), y, junto con ellos, además, todos los casos de vis compulsiva que no sean susceptibles de incriminación a título de amenaza grave (afectación de las condiciones del medio ambiente).

Más allá de esta restricción, cualquier criterio demarcatorio será inevitablemente arbitrario, y tendrá que enfrentarse con las dificultades inherentes a su implementación en la praxis judicial. En el caso del criterio propuesto por Mera -ejercer violencia es cometer lesiones menos graves o crear un peligro concreto para la vida o la integridad personal-, se trata de un criterio doblemente arbitrario. Pues por una parte prescinde del modo de ataque o forma de acción que causa alguno de esos resultados, y por otra parte prescinde asimismo de cualquier consideración funcional entre violencia y coacción.

Bajo el imperio de la interpretación more Mera, por ejemplo, la praxis tendría que considerar por lo general como robo el caso del que engaña a otro y lo hace caer al suelo para que suelte la cosa que porta consigo, ya que provocar una caída producirá por lo general una situación de peligro para la integridad corporal. $\mathrm{Y}$, a la inversa, tendría que sancionar por simple hurto a los matones que para despojar a una anciana la sujetan con tal superioridad de fuerzas que pueden controlar completamente sus movimientos, porque de quien manteniendo esa capacidad de control causal no irroga un daño no puede decirse que haya creado una situación de peligro.

Afortunadamente, la jurisprudencia no ha recepcionado la tesis de Mera en cuanto a la interpretación de la violencia como medio comisivo del robo ${ }^{174}$.

172 Para un vistazo general de este fenómeno en la doctrina española, José Luis Díez Ripollés, Luis Gracia Martín, Delitos contra bienes jurídicos fundamentales, Valencia, 1993, p. 296 y ss.

173 Este es el mismo sentido que, en general, los autores alemanes asignan a la expresión "Gewalt gegen die Person" ("violencia contra la persona"), utilizada por el texto legal a propósito de la configuración de la acción punible en los delitos de robo y extorsión calificada (vid. nota 5).

${ }^{174}$ Hace más de treinta años, la Excma. Corte Suprema sostuvo que el art. 439 no exige irrogación de lesiones corporales para calificar una acción de ejercicio de violencia, y que lo esencial es su funcionalidad coercitiva (contra Custodio Lagos M., sentencia de 21 de Diciembre de 1996, en: Revista de Derecho y Jurisprudencia, LXIII (1966), $2^{\text {a }}$ Parte, Sección $4^{\text {a }}$, p. 444-446). Este fallo ha sido respaldado en tiempos recientes por la Iltma.. Corte de Apelaciones de Santiago (contra Cristopher Orellana González, sentencia de 18 de Mayo de 2000, en: Revista Gaceta Jurídica N 239 (2000), p. 142-143), e incluso por la Iltma.. Corte de San Miguel, en sentencia redactada por Carlos Künsemüller Löebenfelder (contra Oscar Garrido Manríquez y otros, sentencia de 14 de diciembre de 1998, en: Revista Gaceta Jurídica N² 22 (1998), p. 159-160). Como dato curioso, cabe señalar que fue apoyándose en este concepto amplio de violencia como Künsemüller justificó inicialmente su 


\subsection{La tesis de la afectación de la seguridad física}

Según Jorge Mera, en la afectación de la seguridad física de las personas se encuentra la única dimensión de injusto adicional a la lesión de la propiedad que puede fundamentar el salto cualitativo que separa al robo del hurto ${ }^{175}$. Esta aseveración se compone de dos enunciados: (a) que lo injusto de la afectación de la seguridad física puede fundamentar el disvalor de injusto del robo, y (b) que lo injusto de la coacción no puede fundamentarlo. El segundo enunciado es falso, como se acaba de demostrar. Ahora corresponde examinar el primero.

Para efectuar ese análisis se debe precisar primero el contenido del concepto de afectación de la seguridad física, ya que su uso en el texto analizado es confuso. Como ejemplo de esta imprecisión puede citarse el siguiente pasaje:

"Creemos que el plus representado por la coacción (...) no es parangonable, en el sistema del Código Penal, al plus que conlleva la afectación de la vida e integridad corporal.

De aceptarse lo anterior, el empleo de la intimidación como medio para obtener la apropiación sólo constituirá robo en los casos en que represente un peligro para la seguridad física de las personas. De ahí, entonces, que deba concluirse que el uso de la violencia que produce dicho peligro, aunque no ocasione un daño efectivo a la integridad puede asimismo, dar lugar al robo.

Nos parece, en consecuencia, que debe aceptararse (sic) que el resultado puede consistir, en principio, en el robo simple, en un peligro para la vida o la integridad corporal." 176

En este fragmento, la noción de la afectación de la seguridad es contrapuesta a la noción de la coacción. La coacción es una estructura de injusto constitutiva de afectación típicamente relevante en el grado máximo (lesión) de un bien jurídico personalísimo (la libertad personal). Pero aquello que es contrapuesto a la coacción no resulta para nada claro en su propia estructura de injusto. Primero se alude a una "afectación" de dos bienes jurídicos personalísimos, la vida y la integridad corporal. En el párrafo siguiente se alude, bajo la misma noción, a un "peligro" para la "seguridad física", que es diferenciado del "daño efectivo" a la "integridad". En el último párrafo se vuelve a aludir a los bienes primeramente mencionados -la vida y la integridad corporal-, pero ahora considerando el resultado no como una afectación sino como un "peligro".

Esta fungibilidad terminológica es un rasgo característico del texto de Jorge Mera. En las poco más de diez páginas que abarcan las tres primeras secciones del capítulo

\footnotetext{
interpretación restrictiva de la intimidación (Contra Juan L. Guzmán Henríquez cit., nota 164, cons. 16 del voto de prevención, p. 149-150). Cómo puede una interpretación extensiva servir de fundamento por analogía para justificar una interpretación restrictiva eso es algo en verdad difícil de comprender.

175 Hurto y robo...cit., p. 111 y ss.

176 Op. cit., p. 118-119.
} 
respectivo ${ }^{177}$, que es donde Mera plantea su tesis interpretativa, se hace mención a este plus de injusto en alrededor de treinta oportunidades. La mitad de las veces se identifica a la seguridad corporal o seguridad física como el bien jurídico involucrado en ese plus de injusto, mientras que en la otra mitad se identifica como tal a la vida y la integridad corporal.

Esta imprecisión aumenta además por el hecho de usarse una terminología profusa e indiferenciada para designar la forma de ataque al bien jurídico, que va desde su simple mención o una vaga referencia a su "afectación", hasta la idea más precisa de la creación de un "peligro concreto", pasando por fórmulas como su "afectación real o potencial", su "daño o peligro", o la creación de un "riesgo" para el bien en cuestión. Todas estas menciones son aplicadas indistintamente a ambos bienes jurídicos, llegándose en ciertos casos a construcciones cuyo sentido dogmático es difícil de desentrañar. Tal es el caso de la fórmula destacada en el propio texto mediante el uso de cursivas como la descripción más depurada de este plus de injusto, y que es del siguiente tenor:

"en el robo simple el empleo de la violencia o de la intimidación debe crear el riesgo efectivo de un peligro de cierta consideración para la seguridad física de las personas" 178 .

Sería en verdad una tarea ímproba descifrar en qué podría consistir este triple peligro, ya que según la fórmula en cuestión la realización del tipo de robo requeriría un peligro (riesgo) efectivo de un peligro de cierta consideración para un estado de ausencia de peligro (seguridad) para la condición física de las personas. Afortunadamente, Jorge Mera incluye una especificación del alcance de su tesis, aclarando que lo que el tipo básico de robo requeriría es la creación de un peligro concreto para la vida o un peligro concreto de que se produzcan lesiones graves ${ }^{179}$.

¿Por qué tanta profusión y fungibilidad de términos para designar esta idea bastante simple? La explicación pareciera ser doble. Por una parte, es evidente que Jorge Mera intenta cubrir con una sola expresión tanto el caso de la lesión menos grave a la integridad corporal (art. 399, que es un caso de "afectación real", en el sentido de "actual", del bien jurídico), como el caso del peligro para la vida o peligro considerable para la integridad corporal ("afectación potencial"), en tanto posibles resultados del empleo de violencia o intimidación en las personas. Para referirse a formas tan disímiles de afectación de un bien jurídico con un mismo concepto se necesita, obviamente, usarlo de modo ambiguo.

Por otra parte, también es claro que sólo el uso de una terminología tan complicada y de un concepto tan impreciso como el de "afectación de la seguridad física" permite presentar con alguna apariencia de plausibilidad una tesis tan inverosímil como lo es sostener que la mera puesta en peligro de la vida o la integridad personal sea portadora de un disvalor de injusto relevante en el contexto del Libro II del Código Penal chileno.

\footnotetext{
177 Op. cit., p. 109-121.

178 Op. cit., p. 121. Este es el sentido con que la tesis de Mera ha sido asumida por la línea jurisprudencial desarrollada por Carlos Künsemüller, eso sí, con total precisión conceptual.

179 Op. cit., p. 119.
} 
No cabe duda que conforme al Código Penal chileno -por lo menos en su regulación originaria- la lesión a la vida humana constituye el injusto material más grave del catálogo de los crímenes y simples delitos contra bienes jurídicos individuales. Se encuentra asimismo fuera de discusión que la lesión de la incolumidad personal puede alcanzar niveles de extrema gravedad, como en los delitos de castración, mutilación de miembro importante o lesiones gravísimas.

De lo anterior no se deduce, sin embargo, que la simple puesta en peligro de esos bienes sea portadora de un disvalor de magnitud equivalente o proporcionalmente menor. El principio general del Código Penal chileno es que la puesta en peligro de esos bienes es punible sólo cuando o bien ocasiona el resultado lesivo de modo objetiva y subjetivamente imputable (delitos de comisión dolosa o negligente de homicidio o lesiones), o bien va acompañada de la intención de producir esa lesión (tentativa acaba o inacabada). Es cierto que existen ciertas excepciones (abandono de niños y personas desvalidas, omisión de deberes de socorro o protección de niños), pero ellas simplemente confirman el principio general del sistema y en ningún caso puede considerarse que sean portadoras de un disvalor considerable. No existiendo -como se ha visto- otra alternativa dogmática para la noción de "afectación de la seguridad física" que la del peligro concreto de estos bienes, fuerza es concluir que esta forma de fundamentar lo injusto del robo carece de todo apoyo en el sistema del Código Penal chileno.

Lo dicho es aún más evidente si se tiene en cuenta lo que Mera sostiene respecto de todas las demás hipótesis de los Libros II y III del Código Penal en que la violencia es medio comisivo. Según él, en estas hipótesis se da una alternativa de tratamiento punitivo entre la sanción por el mero uso de violencia, sin requerirse peligro para la vida o integridad corporal, y el concurso ideal por el delito de violencia y el resultado de homicidio o lesiones efectivamente producido. Con su interpretación de la violencia en el robo, Mera pretende dar una explicación para el hecho que todos los demás supuestos de coacción reciben una pena inferior. Pero la misma explicación implica que la producción de un resultado de peligro concreto sin causar el resultado de lesión -que es el momento intermedio entre la simple violencia y la causación de la lesión- es absolutamente irrelevante en todos estos casos. Conforme a la interpretación de Mera, lo que por regla general es irrelevante tendría una importancia crucial en el robo; la dimensión de injusto que por regla general es atípica brindaría a propósito del robo el núcleo material de lo injusto de un crimen. El pretendido fundamento en el sistema del Código se revela así como una anomalía sistemática.

Por cierto que una incongruencia de tal magnitud con el derecho positivo chileno no podía escapársele a Jorge Mera, quien reconoce el hecho y ensaya una explicación. El pasaje merece ser trascrito:

"La explicación de por qué la ley se apartó, precisamente a propósito del robo con violencia o intimidación en las personas, de su predicamento general en el sentido de prescindir del plus de desvalor constituido por el peligro que para la integridad corporal pueda comportar el uso de la violencia, se encuentra seguramente en el hecho de que, por su mayor frecuencia, tiene también mayor relevancia social la violencia que se emplea en la apropiación de las cosas, que la usada con otros fines. Esto aparentemente 
justificaría, en el concepto de la ley, abandonar el criterio general de la impunidad por la sola producción del peligro para la seguridad corporal. En definitiva se trataría de una razón utilitaria fundada en la prevención general." 180

Como recurso final de la teoría defendida por Mera este argumento es en verdad desconcertante. Esta teoría rechaza la interpretación de los términos "violencia" e "intimidación" que es tradicional en la doctrina y la jurisprudencia, sosteniendo que ella "no resiste análisis, ni aún dentro de la lógica y de los principios sistemáticos del propio Código", y asevera que su interpretación alternativa es la única que resulta "consistente con el propio sistema del Código Penal"181. Además, la teoría invoca como principal parámetro de evaluación de la aceptabilidad de una construcción dogmática el que permita hacer de la pena una sanción "justa, racional y proporcionada"182.

No obstante todos estos presupuestos, en este pasaje se termina reconociendo que la interpretación defendida por esta teoría no concuerda con el sistema del Código ni tampoco responde a una jerarquización proporcional al disvalor material de la conducta. Lo más increíble de este reconocimiento es que se remite en definitiva a una supuesta apreciación legislativa de consideraciones puramente estratégicas.

Tratándose de un autor que ha acusado a la doctrina y jurisprudencia española y chilena, que ha sido constante por más de siglo y medio, de no haber "reflexionado suficientemente" sobre los conceptos de violencia e intimidación, en el sentido de no haberlos "relacionado cabalmente" con la "extraordinaria gravedad" del delito de robo ni con su "carácter complejo y pluriofensivo"183, resulta en verdad difícil de creer que él no tenga en definitiva otra explicación para la magnitud de la pena del robo que una consideración de prevención general del legislador, o, lo que es lo mismo, la atribución discrecional por parte del legislador de un carácter socialmente intolerable en grado sumo a esta forma de apropiación. ¡Una decisión arbitraria del legislador puede predicarse de cualquier norma o disposición, sin que de ello quepa deducir un fundamento políticocriminal concluyente!

Por cierto, con este reconocimiento final de la falta de fundamento jurídicomaterial de su teoría Jorge Mera brinda un fundamento adicional a la concepción del robo como coacción. Pues, si no es contrario a las normas y principios internacionales sobre derechos humanos que el legislador, movido por una razón utilitaria, transforme en crimen una conducta que conforme a las restantes disposiciones legales es impune, mucho menos lo será que eleve a crimen la pena de un simple delito. Si Jorge Mera en verdad considera que su último recurso tiene algún valor argumental, entonces no puede dejar de reconocer que es aplicable con mucho más procedencia sobre el horizonte dado por las amenazas condicionales que a la puesta en peligro de la vida o la integridad corporal.

\footnotetext{
180 Op. cit., p. 121.

181 Op. cit., p. 113.

182 Op. cit., loc. cit.

183 Op. cit., p. 109-110.
} 


\subsection{La interpretación desde el robo calificado}

Una de las afirmaciones recurrentes de Jorge Mera para fundamentar su interpretación es la de sostener que el robo es un delito complejo y pluriofensivo, en el sentido de suponer algún grado de afectación a la vida y la incolumidad personal además del atentado a la propiedad. El rechazo de la libertad personal como bien jurídico adicional y típicamente relevante obedece, como se ha visto, a lo insuficiente de su análisis dogmático de lo injusto de la coacción. Pero Jorge Mera dispone de otro argumento para justificar ese rechazo, y ese es la interpretación del tipo básico de robo desde la estructura típica del robo calificado. Del carácter manifiestamente ofensivo de la vida, la incolumidad personal, la autodeterminación sexual y la libertad ambulatoria, además de la lesión de la propiedad y la libertad, que tienen las distintas hipótesis de robo calificado, Mera deduce la necesidad de constatar una dimensión semejante de pluriofensividad para el robo simple ${ }^{184}$.

Esta interpretación "desde arriba hacia abajo" de las relaciones sistemáticas existentes entre las distintas hipótesis típicas del delito de robo es aducida también por Juan Bustos Ramírez como argumento para exigir en el tipo básico de robo "una violencia con un efecto de cierta intensidad"185. El contexto en que Bustos formula esta exigencia es sin embargo completamente diverso al contexto en que Mera pretende invocar el mismo argumento. Con este argumento, Bustos intenta ofrecer un criterio demarcatorio del concepto de violencia, para concretar el postulado del robo con violencia como una coacción violenta grave, en el sentido arriba expuesto (supra, 4.2-b), es decir como un delito que supone como nota esencial un ataque a la libertad ${ }^{186}$. Mera, en cambio, formula una interpretación desde el robo calificado para negar la relevancia del ataque a la libertad personal como elemento de lo injusto del robo simple.

La verdad es que, como lo ha puesto de manifiesto Ruiz Antón, desde un punto de vista metodológico el único procedimiento correcto es el de construir primero el concepto del delito básico o genérico, para luego sobre su base proceder a la construcción de las variantes calificadas o las hipótesis especiales ${ }^{187}$. Esta recomendación de método pasa a ser imperativa en un contexto regulativo como el chileno, en el cual la tipificación del robo calificado carece por completo de un fundamento sistemático, como arriba se demostró (supra, sección 3.4). Sólo una interpretación "desde el robo simple hacia el robo calificado" permite reconstruir racionalmente el modelo regulativo de las calificaciones propias y diferenciarlas de las calificaciones impropias. Optar por hacer de los dos numerandos del art. 433 C.P. la base de la reconstrucción conceptual del robo equivale a demoler sus cimientos.

184 Op. cit., p. 113-115, 115-118.

185 Manual...cit. [nota 157], p. 175.

186 Op. cit., p. 174. Por esta razón, se puede decir que el criterio de Bustos es en definitiva incongruente con su propia concepción del delito de robo como coacción.

187 El robo...cit. [nota 2], p. 1053 y ss. De este planteamiento correcto Ruiz Antón deduce, a mi juicio apresuradamente, que el tipo básico de robo debe encontrarse siempre en concurso ideal con los delitos de lesiones cuya comisión no realiza alguna hipótesis de robo calificado. En su opinión, de lo contrario el intérprete postularía la existencia de más tipos complejos que los expresamente configurados por el legislador. La tesis de Ruiz Antón desconoce sin embargo que en muchos casos la afirmación por el intérprete de un concurso aparente cumple materialmente la misma función de un tipo complejo configurado por el legislador, y que en definitiva la línea demarcatoria entre el concurso ideal y el concurso aparente descansa también en consideraciones materiales. 


\section{Consideraciones de lege ferenda}

\subsection{La racionalidad político-criminal de la penalidad y la regulación del delito de robo}

Jorge Mera sostiene que no se puede razonablemente atribuir a la apropiación coercitiva un disvalor superior al del homicidio ${ }^{188}$. Esta aseveración es indiscutible. Pero lo mismo vale, y con mayor fuerza aún, para la apropiación acompañada de lesiones menos graves o de una puesta en peligro de la vida o la incolumidad personal. No cabe duda que la penalidad del robo simple introducida por la Ley 11.625 es desproporcionada en relación con su disvalor de injusto, cualquiera que sea la perspectiva desde la cual se determine éste.

¿Es jurídicamente válida esta decisión del legislador? La respuesta a esta interrogante no es tarea fácil, ya que a ella son aplicables dos principios fundamentales del Estado democrático de Derecho, que se encuentran en tensión entre sí. Por una parte, el principio de la proporcionalidad prohibe al legislador el exceso en la determinación de la reacción estatal al injusto merecedor y necesitado de pena. Por otra parte, el principio de la democracia reconoce al legislador una amplia prerrogativa de decisión de cuestiones de política criminal. Tampoco debe olvidarse que la política criminal es una manifestación de la política jurídica, y que un régimen constitucional que garantiza el pluralismo ideológico se basa en el principio de la legitimidad inicial de la diversidad de opciones de política jurídica. Pretender que conforme a la Constitución o a las convenciones internacionales hay una única política criminal legítima es un planteamiento antidemocrático.

¿Es invalidable $-\mathrm{O}$, en los términos de la Constitución chilena, susceptible de declaración como "inaplicable"- la decisión del legislador de 1954 en virtud del principio de la proporcionalidad? ¿Le está constitucional o internacionalmente prohibido al legislador chileno establecer una pena de cinco a veinte años de presidio para la apropiación coercitiva? Sólo si se admite lo anterior puede postularse una "interpretación restrictiva" en el sentido de la desarrollada por Jorge Mera, a fin de evitar la invalidación o inaplicabilidad del precepto legal (principio de la conservación). Mientras no se lo demuestre, lo único que puede aseverarse es que la decisión del legislador chileno no es razonable, en el sentido que requiere ser modificada por una reforma legislativa. Si el orden constitucional supone la división de poderes, y si la prerrogativa de decisión de la política jurídica se radica en el órgano legislativo, como corresponde conforme al principio de la generación y representación democrática, entonces las consideraciones de lege ferenda no pueden valer como consideraciones de sentencia ferenda cuando contradicen la voluntad manifiesta del legislador histórico.

Analizando ahora de lege ferenda la regulación del robo, es importante destacar que en su evolución histórica el Código Penal chileno ha conocido dos modelos políticocriminales distintos, el originario del Código de 1874 y el introducido con la reforma de 1954. En el primer modelo, el tipo básico de robo se mueve en un marco penal intermedio entre el del simple delito y el del crimen, y para los casos de mayor peligrosidad establece hipótesis calificadas junto con los supuestos de comisión de otros delitos. En el segundo modelo, el tipo básico de robo es constitutivo de crimen, las

188 Hurto y robo...cit., p. 112-113. 
hipótesis calificadas sólo se refieren a los supuestos de comisión de otros delitos, y los casos de mayor peligrosidad configuran agravantes.

La concepción del robo como apropiación coercitiva concuerda mejor con el modelo originario del Código Penal chileno, y en esa misma medida provee argumentos para evaluar críticamente la reforma introducida en 1954 por la Ley 11.625. Para quien concibe al tipo básico de robo como apropiación coercitiva de cosa mueble ajena, resulta evidente la desproporción de la pena asignada a este delito. Por el contrario, la concepción del robo como apropiación peligrosa brinda una justificación político-criminal al modelo regulativo introducido en 1954, y en esa misma medida obstaculiza la crítica a la legislación vigente. Esto es manifiesto en las propuestas de lege ferenda de Jorge Mera. En vez de exigir la restitución de un marco penal adecuado para el tipo básico y la reformulación legislativa de la idea de la comisión del delito con peligro para la vida o la incolumidad personal, Mera propone tratar a la apropiación coercitiva como un caso de hurto agravado y dejar subsistente el tipo básico de robo como expresión de la apropiación peligrosa ${ }^{189}$.

Lo más notable de esta propuesta de Jorge Mera es que ella es elaborada en manifiesta contradicción con la evaluación que este autor hace de la reforma legal que le dio origen. En su breve apreciación crítica de la evolución histórica del delito de robo, Jorge Mera constata la correspondencia existente entre el derecho comparado y el modelo regulativo originario del Código Penal chileno, calificando el régimen de penalidades de este modelo como "razonable" y "proporcionado"190. La elevación de las penas efectuada por la Ley 11.625 le parece, por el contrario, una decisión irracional y desproporcionada, basada en un cálculo optimistamente infundado en el efecto disuasivo de la magnitud de la pena ${ }^{191}$. A pesar de esta apreciación, Mera sostiene en su libro, sesenta páginas después, que la drástica elevación de la pena del delito de robo ocurrida en 1954 es expresión de la extraordinaria gravedad de este delito que se basa en su particular naturaleza compleja y pluriofensiva, deduciendo de ello consecuencias para disolver la estructura de injusto que originariamente tenía esa pena razonable y proporcionada.

De todos los problemas que origina el planteamiento de Jorge Mera, el más grave es sin duda esta distorsión de los parámetros de política-criminal que deben orientar la reforma del delito de robo. Para demostrar esa distorsión basta con hacer un breve ejercicio argumentativo.

Adoptando como parámetro el derecho comparado, en abstracto no es difícil diseñar un modelo regulativo para el robo que sea político-criminalmente razonable, incluso desde la perspectiva de la proporcionalidad de las penas defendida por Jorge Mera. Tal sería, por ejemplo, una regulación que partiera de un tipo básico de apropiación coercitiva, al cual asignara una pena que oscilara, por ejemplo, entre uno y siete años de pena privativa de libertad. La regulación podría contemplar además hipótesis calificadas que comenzaran por la producción de un peligro serio para la incolumidad personal, pasaran por el porte o uso de armas, la pertenencia a una asociación ilícita dedicada al robo y el hurto, el maltrato grave de la persona y la creación de un peligro para la vida, y terminaran con la penalidad más grave para la causación de un resultado de muerte

\footnotetext{
189 Op. cit., p. 118-119, 135, 139-141, 146-147.

190 Op. cit., p. 38, 39.

191 Op. cit., p. 40, 41.
} 
objetiva y subjetivamente imputable al partícipe en la apropiación coercitiva. Los marcos penales asignables a estas hipótesis calificadas deberían ser también diferenciados, tomando principalmente en consideración los márgenes inferiores de la pena. El margen superior máximo encontraría su límite en la pena del homicidio calificado, la cual en ningún caso podría ser sobrepasada por la pena asignable a la hipótesis de robo con homicidio ${ }^{192}$.

Este modelo regulativo supone un punto de partida determinado, distinguible del resto de los delitos de apropiación, en particular de los casos de hurto en cuya comisión puede constatarse también una situación de peligro para la vida o la incolumidad de las personas, como es el hurto cometido con porte de armas. Tal es el caso de la apropiación coercitiva, que por el nexo funcional entre apropiación y coacción violenta o intimidatoria supone una potenciación del disvalor de injusto que va más allá de la mera suma de los disvalores que la componen y que otorga una base adecuada para construir el régimen de penalidades calificadas por la concreción de esa potenciación ${ }^{193}$.

Pretender construir el tipo básico del robo directamente en la idea de una comisión peligrosa, prescindiendo de la coacción como elemento de injusto del robo -tal como lo hace Mera- impide reconocer el núcleo de la dinámica comisiva del robo como un tipo de injusto diferenciable del hurto y que hace necesario o conveniente el régimen de calificaciones. Asimismo, sólo la concepción del robo como apropiación coercitiva permite identificar cuán anómala es la extensión de la penalidad a los casos de coacción previa o posterior a la apropiación, y en consecuencia formularla con una adecuada técnica legislativa.

En lo que respecta a la calificación por la comisión peligrosa o creación de un peligro, ella requiere una configuración diferenciada. Si bien la base de esta calificación debe encontrarse en un incremento de la peligrosidad objetiva de la comisión de la acción típica para la vida o la incolumidad personal, para que esta idea satisfaga las exigencias del principio de legalidad se requiere que las hipótesis se construyan sobre la base de la identificación precisa de las formas de comisión peligrosa.

Una de estas formas es el uso de un arma peligrosa, concepto éste que la ley debe explicitar en el sentido de un peligro objetivo que sobrepase la simple función coercitiva de la amenaza con usar dicha arma. Otra forma de comisión peligrosa es la que corresponde a la antigua idea de la comisión "en cuadrilla", y que coincide con la figura de la "banda" de personas dedicadas al robo o la hurto; la dificultad técnica de esta hipótesis radica en encontrar ese punto intermedio entre la mera coautoría en el robo y el delito adicional de asociación ilícita, que es lo que caracteriza a la banda como forma especialmente peligrosa de comisión. La tercera forma de comisión peligrosa es la que consiste en la creación de un peligro concreto para la vida o de un peligro concreto y grave para la incolumidad personal. Esta calificación debe diferenciar entre uno y otro peligro, y su introducción en el delito de robo debe ir acompañada de una reforma de los

\footnotetext{
192 Esta es, en grandes rasgos, la regulación del robo en el Código Penal alemán después de las modificaciones recientemente introducidas por la $6^{a}$ Ley de Reforma Penal, de 26 de Enero de 1998. La concreta configuración del robo calificado después de esta ley fracasa, sin embargo, en la identificación del peligro objetivo como fundamento de las calificantes. Al respecto, vid. Günther, op. cit., [nota 5], \$250, núms. 1 y ss.

193 Así, Günther, op. cit. [nota 5], §249, núm. 1.
} 
delitos de lesiones, conforme a la cual no sólo la irrogación de un daño grave sino además la creación de un peligro grave dé lugar a la aplicación de penas de consideración.

A primera vista podría estimarse que el planteamiento de Jorge Mera implica un avance en el reconocimiento de esta forma de calificación del robo, ya que, en los hechos, su interpretación equivale a transformar el tipo básico de robo en un tipo calificado por la creación de un peligro objetivo. Ese no es, sin embargo, el caso. El planteamiento de Mera se basa en la postulación de un concepto indiferenciado de peligro, que no requiere la concurrencia de otro elemento fáctico que el ejercicio de violencia o intimidación, que equipara el peligro para la vida con el peligro para la incolumidad personal, y que en virtud de su inespecificidad puede absorber cualquier forma concreta y diferenciada de creación de un peligro, como lo son algunas de las agravantes del art. 456 bis. Además, Mera postula la existencia de un tipo de robo con peligro para la vida y la integridad personal sin postular la necesidad de introducir el mismo modelo regulativo en el contexto de los delitos de lesiones.

El punto donde se hacen más evidentes los efectos indeseables del planteamiento de Mera es en el examen de lege ferenda de las hipótesis calificadas por la comisión de delitos adicionales. Tratándose de la comisión de los delitos de violación y secuestro extorsivo, la derogación de estas hipótesis y su remisión al régimen general de concursos encuentra su mejor fundamento en la concepción del robo como coacción. Es la constatación de la inexistencia de una relación funcional entre violación o secuestro y apropiación que sea reconducible a la relación funcional entre apropiación y coacción lo que demuestra que no hay razones para justificar una excepción al régimen general de concursos (real o material, en este caso). En cambio, para una concepción que ve en la complejidad y pluriofensividad del delito de robo su rasgo definitorio desde un punto de vista político-criminal, resulta difícil impugnar la procedencia de la tipificación de estos supuestos. En efecto, no hay nada más "complejo y pluriofensivo" que hacer de un caso de concurso real de delitos un solo supuesto típico.

Tratándose ahora de la comisión de homicidio y lesiones gravísimas, la concepción del robo como coacción exige desde un punto de vista político-criminal una nítida diferenciación de las tres posibles formas de relación entre la apropiación coercitiva y la acción homicida o lesiva. La relación de simple coincidencia temporal debe seguir la misma suerte que el caso anterior, y quedar por lo tanto sometida al régimen general de concursos. La necesidad social de sentir mayor seguridad frente al salteo, tan relevante en el siglo pasado, ha perdido su intensidad en la misma medida en que han aumentado las posibilidades de comunicación y la capacidad de reacción policial.

En lo que respecta a la relación subjetiva entre el homicidio o las lesiones precedentes a la apropiación y deliberadamente cometidos para remover los posibles obstáculos a ésta, ella no es razón suficiente para que el caso ingrese al contexto regulativo y represivo del robo. Angel Torío López ha defendido persuasivamente la misma tesis, por razones criminológicas y simbólicas, sosteniendo que el "homicidio preordenado al robo" - a la apropiación, se entiende- debe ser sustraído del campo de los delitos patrimoniales, para configurar un supuesto de asesinato u homicidio calificado por el ánimo de lucro o la codicia ${ }^{194}$. Desde un punto de vista dogmático, la diferencia entre este

${ }^{194}$ La distinción legislativa entre asesinato y robo con homicidio, en: Estudios Penales, Tomo VIII (1984), p. 451 y ss. 
homicidio preordenado a la apropiación y el robo con homicidio es tanto de carácter objetivo como subjetivo.

Objetivamente considerada, la diferencia se encuentra en la existencia o inexistencia de una coacción. Esta diferencia tiene una importante concreción en la cuestión de los medios comisivos del homicidio: mientras que el homicidio preordenado a la apropiación comparte plenamente el carácter de delito resultativo del homicidio, y por lo tanto cualquier medio comisivo idóneo es típicamente relevante, en el robo con homicidio la muerte debe ser la consecuencia de una acción típicamente relevante en el sentido del robo, como lo es paradigmáticamente el uso de violencia coercitiva.

Desde un punto de vista subjetivo, la diferencia se encuentra en la naturaleza de la relación subjetiva entre la muerte y la apropiación. En el caso del homicidio calificado, el dolo recae sobre la muerte de otro, desempeñando la codicia o el ánimo de lucro el papel de un especial elemento de la culpabilidad. Por eso es que resulta irrelevante la tipicidad del modo de enriquecimiento perseguido con el homicidio, el cual podrá por cierto consistir en una acción de apropiación, pero igualmente podrá tratarse de la extinción de una deuda, o del cobro de un seguro, o de la sucesión hereditaria de la víctima. Por la misma razón, para el caso en que el enriquecimiento perseguido con el homicidio sea típicamente antijurídico, es del todo irrelevante el iter criminis de esa acción. Ya sea que se pretenda obtener el enriquecimiento mediante la comisión de un hurto, una apropiación indebida o una estafa, la punibilidad del homicidio calificado es por completo independiente de la concreta punibilidad del atentado a la propiedad o el patrimonio.

En el robo con homicidio en sentido estricto, en cambio, la muerte es un resultado subjetivamente imputable a la acción de constreñir mediante violencia o intimidación. Para la configuración del tipo subjetivo del robo con homicidio, esto significa que por lo general el resultado de muerte o lesión representará un exceso respecto del contenido del dolo directo del autor del robo, dirigido a la coacción y a la apropiación.

La insistencia con que la doctrina chilena exige dolo respecto del homicidio (supra, sección 3.4), amenaza con distorsionar la única perspectiva político criminal correcta, cual es la de considerar al robo con homicidio como un delito calificado por la producción de un resultado grave, imputable al autor del delito al menos a título de imprudencia. Esta diferenciación sólo puede hacerse desde la perspectiva de la concepción del robo como coacción. Si, por el contrario, se considera al robo como un hurto con peligro concreto para la vida o la incolumidad personal, entonces no hay forma de justificar políticocriminalmente la distinción entre asesinato por codicia y robo con homicidio. Todas las consecuencias dogmáticas de esta diferenciación -que son hasta intuitivamente evidentesdeben disolverse y fusionarse en el magma de la pluriofensividad del robo.

\subsection{El futuro legislativo de la apropiación coercitiva}

El modelo regulativo presentado en la sección anterior como un esquema político-criminalmente razonable parte de la tipificación del robo como apropiación coercitiva. Jorge Mera discrepa de este punto de partida. A su juicio, desde un punto de

[esp. p. 464-468]. 
vista político criminal la apropiación coercitiva no es algo significativamente diverso de la mera apropiación ${ }^{195}$.

Esta tesis tiene a su favor el hecho de identificar uno de los puntos de más difícil tratamiento dogmático del delito de coacción, como es el de sus relaciones concursales con los demás delitos de la Parte Especial, que no son supuestos especiales de coacción. Para decirlo en los términos de Binding ${ }^{196}$, se trata de resolver la cuestión de las relaciones concursales entre el ataque a la manifestación de la voluntad y el ataque a la voluntad manifestada, cuando es idéntico el objeto en que se concreta la voluntad atacada. Para reforzar el punto de vista de Mera basta con suponer que, por ejemplo, el objeto de la voluntad manifestada sea la indemnidad personal. Este es el caso de quien ejerce violencia sobre otro para constreñirlo a tolerar el padecimiento de una lesión corporal. ¿Hay en este caso un concurso ideal o un concurso aparente de delitos?

Es posible imaginar diversos casos en que la evidencia intuitiva oscile entre una y otra solución posible, e incluso pensar casos en que el ejercicio de coacción pueda hasta fundar la incriminación a título de lesiones, como en supuestos de coautoría. Pero siempre se encontrará como horizonte de referencia la postulación de un concurso aparente, en el que la incriminación de las lesiones consumirá la coacción. Ello se debe a una reflexión elemental: si la comisión de un delito implica que la víctima tenga que tolerar ese hecho, en su incriminación tendrá por regla general que entenderse asumida y expresada dicha situación de la víctima.

En el robo, sin embargo, ese horizonte aparece invertido de modo tal que la posibilidad de apreciar un concurso aparente entre hurto y coacción, resuelto a favor del primero por el principio de la consunción, queda excluida por decisión del legislador. Ciertamente hay aquí una anomalía. Su explicación pareciera obedecer a dos órdenes de razones.

En primer lugar, es posible apreciar una diferencia entre la concreción de la voluntad manifestada en cosas o en el cuerpo de la persona. La afectación de la voluntad manifestada en cosas es fácilmente concebible al margen de la afectación de la manifestación de voluntad de su titular, porque semejante afectación es por regla general susceptible de comisión sin que lo advierta ese titular. En este sentido, la propiedad mueble se encuentra en una situación de estrecho paralelismo con la propiedad inmueble y la intimidad espacial. Esta situación es claramente diferenciable de la en que se encuentra la incolumidad personal, cuya afectación es percibida por el titular de la voluntad con tal que se encuentre en estado consciente.

En segundo lugar, la regulación diferenciada de la pura apropiación y la apropiación coercitiva pareciera de algún modo reproducir la distinción entre interacción fraudulenta e interacción coercitiva. Desde este punto de vista, el hurto y la estafa compartirían el carácter de delitos clandestinos, frente al robo y la extorsión, que serían delitos de fuerza. Este paralelismo morfológico no tiene gran peso dogmático, sino que corresponde a criterios criminológicos y filosófico-morales. Con todo, él pone de manifiesto que aún si se decidiera aplicar estrictamente el criterio de la consunción de la

195 Hurto y robo...cit, p. 137.

${ }^{196}$ Lehrbuch des Gemeinen Deutschen Strafrechts, Erster Band, Leipzig, 1902, \21, p. 80-81. 
coacción en el delito a cuya comisión la víctima fue constreñida, lo injusto del robo nunca podría desaparecer del todo del sistema de la Parte Especial.

La necesidad de contar con un delito de coacción patrimonial dentro del sistema de la Parte Especial viene impuesta por la obvia posibilidad de considerar el ataque al patrimonio directamente como un ataque al libre desarrollo de la personalidad. Desde el punto de vista del delito de coacción, es evidente que la coacción que acarrea un resultado lesivo de un presupuesto del libre desarrollo de la personalidad que trasciende la restricción momentánea de la capacidad de acción, como es el perjuicio patrimonial, merece -y en general también necesita- un título especial y más severo de incriminación. Tal es el delito de extorsión, en el cual el resultado de la coacción es un acto de disposición patrimonial que acarrea como consecuencia un empobrecimiento.

Visto desde esta perspectiva, todo robo que implica un acto de disposición patrimonial es digno de sanción como un delito especial de coacción. Para la regulación futura del Código Penal es perfectamente imaginable un sistema en el que las alternativas de incriminación para la apropiación coercitiva fueran el hurto -en discutible concurso con la coacción- o la extorsión, correctamente configurada como tipo paralelo a la estafa y con un régimen de penalidad bien diferenciado.

Jorge Mera postula en cambio como solución de lege ferenda la configuración de una agravante para el hurto, cuyo fundamento no estaría en la lesión a la libertad personal sino en la afectación del sentimiento de tranquilidad y seguridad ${ }^{197}$. Con ello, Mera desconoce que la afectación de ese bien sólo es jurídico-penalmente relevante cuando es sometida a requisitos formales muy estrictos (amenaza simple) o en la medida en que es un medio de coacción (amenaza condicional). No satisfaciéndose los requisitos formales, si lo injusto de la coacción debe diluirse en lo injusto de la apropiación, desaparece la relevancia de la afectación del sentimiento de seguridad y tranquilidad. Por otra parte, esta aparente solución no haría sino introducir una nueva fuente de dificultades en el sistema de la Parte Especial, como sería el del tratamiento correcto para los casos de apropiación coercitiva cuando la acción fuera más severamente punible a título de coacción patrimonial (extorsión o amenaza condicional).

Así se confirma lo dicho desde la primera página de este artículo: sin tomar en consideración lo injusto de la coacción no se puede comprender dogmáticamente, ni resolver político-criminalmente, los intrincados problemas que plantea la regulación del delito de robo.

\subsection{Resumen final}

Para finalizar, resulta conveniente resumir aquí el planteamiento defendido en estas páginas, expresándolo en tres tesis, opuestas a las tres tesis básicas de Jorge Mera:

Primera tesis: El robo con violencia o intimidación en las personas es un delito cuyo tipo de injusto es complejo y pluriofensivo, en el sentido que se compone al menos en su núcleo- de dos tipos de injusto diferentes, el del hurto y el de la coacción (coacciones violentas y amenazas condicionales).

197 Op. cit., p. 140 y 146. 
Segunda tesis: Desde el punto de vista del sistema de los delitos de coacción, el robo tiene la inusual categoría de un crimen de coacción. La gravedad del marco penal establecido como consecuencia jurídica de su comisión exige considerarlo como una coacción especialmente grave. Para concretar esta consideración se requiere constatar una especial gravedad en el medio comisivo empleado. Tal es la intimidación como amenaza de irrogación inminente de un mal grave, y la violencia en la persona como supresión de la capacidad personal -y no meramente instrumental- de formación o ejecución de la voluntad.

Tercera tesis: La creación de un peligro concreto para la vida o un peligro grave para la incolumidad personal no desempeña rol alguno como presupuesto de lo injusto del tipo básico de robo ${ }^{198}$.

Las consecuencias prácticas de esta concepción pueden resultar parcialmente inconvenientes por razones de justicia material, ya que ella admite la aplicación de una pena severísima para casos en que la concepción del robo como apropiación peligrosa excluiría de su ámbito de aplicación, y también admite la posibilidad de agravar dicha pena por la concurrencia de circunstancias que la concepción del robo como apropiación peligrosa también descarta.

Desde un punto de vista dogmático y de política criminal, esto queda sin embargo más que compensado con todas las desventajas que se siguen de prescindir de la concepción del robo como apropiación coercitiva. En efecto, sólo desde la perspectiva del robo como coacción es que se puede identificar y manejar restrictivamente a todas las decisiones extensivas del ámbito de aplicación de la pena del delito de robo contenidas en el art. 433 C.P., exigir imputación objetiva entre el ejercicio de violencia o intimidación coercitivas y un resultado de coacción, y entre éste y la realización de la acción de apropiación, deslindar el robo del así como alternativa a la regulación actual, denominado "robo por sorpresa", y elaborar un modelo político-criminalmente razonable de regulación

La más importante de las consecuencias de la concepción del robo como coacción es sin embargo la de dejar en evidencia la irracionalidad de la legislación vigente. La exclusión de algunos casos del ámbito de aplicación de la pena del art. 436 es una victoria pírrica, si para lograrlo se debe asignar a esa disposición legal una apariencia de racionalidad de la cual carece.

La Ley 11.625 no estableció una regulación a la cual subyazca una ratio determinada, consistente en expresar los arcanos del delito de robo, ocultos hasta su develamiento oracular en 1994. La Ley 11.625 no es más que un eslabón en la cadena de reacciones puramente simbólicas del legislador frente al robo que ha caracterizado la historia legislativa chilena. Esta cadena, que hunde sus raíces en la legislación de Felipe V, se evidenció tempranamente, con el decreto de 9 de Junio de 1817 de Hilarión de la Quintana, por el cual se declaró "que todo el que robase de cuatro pesos para arriba será

\footnotetext{
198 Sí lo era en el texto originario del Código Penal, que regulaba diversas hipótesis de robo calificado bajo la idea del salteo (vid. supra, nota 106). La Ley 11.625 dio a estas hipótesis una nueva configuración y las reguló como agravantes especiales (art. 456 bis), tanto del robo simple como de las nuevas hipótesis de robo calificado; lo mismo hizo la Ley 11.625 con la circunstancia de portar o usar armas (art. 450 inciso segundo), que originariamente servía de criterio de configuración de las hipótesis más graves de hurto (art. $447 \mathrm{~N}^{\circ} 1$ ) y robo con fuerza en las cosas (arts. 440, 441). La historia legislativa demuestra que el criterio de la peligrosidad objetiva es actualmente ajeno a la configuración de lo injusto de los delitos de apropiación.
} 
pasado por las armas" ${ }^{199}$, para reaparecer más tarde con la dictación de la Ley de 5 de Octubre de 1876, que ordenó la pena de muerte para el culpable de robo o de tentativa de robo "que al mismo tiempo se hiciere reo de homicidio, violación u otra injuria grave de obra contra las personas"200, hasta llegar a la Ley 11.625.

Frente a esta irracionalidad legislativa, la interpretación "rectificadora" que aquí se ha criticado equivale al discurso del sastre que trata de convencer al Emperador de que el traje que lleva es tan delicado que no puede realizar movimientos bruscos. Lo que en estas páginas se ha sostenido es que, por el contrario, hay que denunciar que el Emperador va desnudo, y en consecuencia admitir que aunque tenga buenas intenciones no por ello deja ese discurso de ser una invención.

199 Boletin de Las Leyes y Decretos del Gobierno, 1817-1818, p. 72.

200 Art. $3^{\circ}$, en: Ricardo Anguita, Leyes Promulgadas en Chile, Tomo II, p. 407. 